\title{
DEVELOPMENT OF A CONTROLLED MATERIAL SPECIFICATION FOR ALLOY 617 FOR NUCLEAR APPLICATIONS
}

Weiju Ren and Robert W. Swindeman

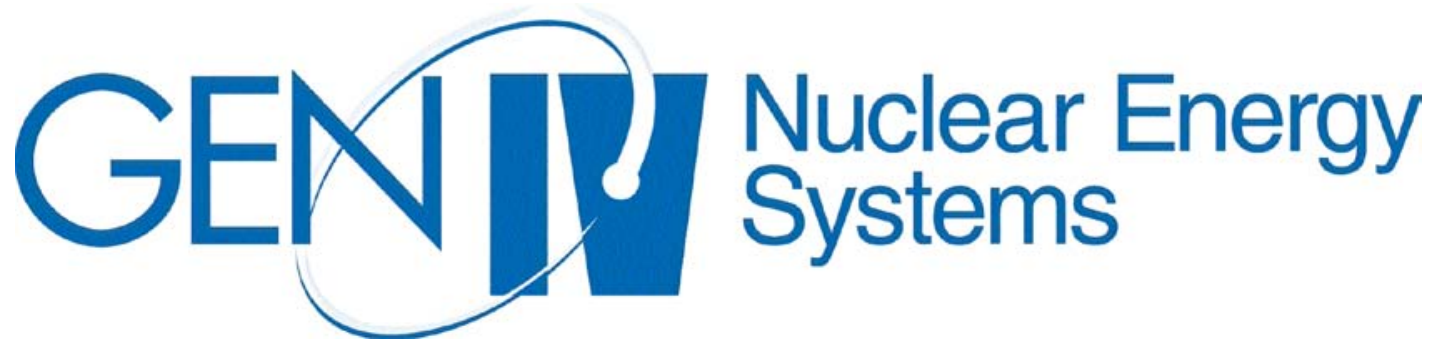

May 31, 2005 


\title{
DEVELOPMENT OF A CONTROLLED MATERIAL SPECIFICATION FOR ALLOY 617 FOR NUCLEAR APPLICATIONS
}

Weiju Ren and Robert W. Swindeman

May 31, 2005

Prepared for

Office of Nuclear Energy Science and Technology

\author{
Prepared by \\ OAK RIDGE NATIONAL LABORATORY \\ Oak Ridge, Tennessee 37831 \\ managed by \\ UT-BATTELLE, LLC \\ for the \\ U.S. DEPARTMENT OF ENERGY \\ Under DOE Contract No. DE-AC05-00OR22725
}


ORNL/TM-2004I 


\begin{abstract}
ABTRACT
Investigation is conducted in an effort to refine the standard specifications of Alloy 617 for the Very High Temperature Reactor applications. Background, motivation and rationale of the investigation are discussed. Historical data generated from various heats of the alloy are collected, sorted, and analyzed. The analyses include examination of mechanical property data and corresponding heat chemical composition, discussion on previous Alloy 617 specification development effort at the Oak Ridge National Laboratory, and assessment of the strengthening elements and mechanisms of the alloy. Based on the analyses, literature review, and knowledge of Ni base alloys, a tentative refined specification is recommended. Future work for verifying and improving the tentative refined specification is also suggested.
\end{abstract}




\section{CONTENTS}

ACKNOLEGMENTS --------------------------------------------------------------------iii

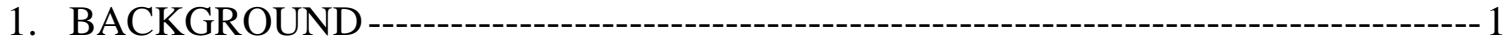

2. THE MATERIAL AND SPECIFICATIONS -

3. TASK ANALYSIS----------

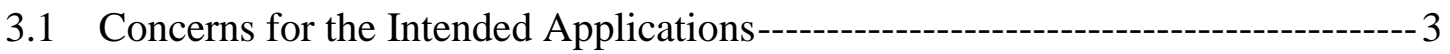

3.2 Goals and Strategies----o-

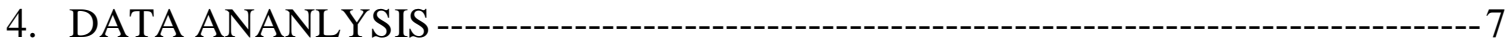

4.1 Status of Mechanical and Chemical Data for Specification Analysis ------------- 7

4.2 Mechanical Property Analysis ---_-----_- 11

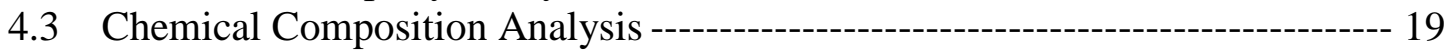

4.4 Previous Specification Development Effort at ORNL ------------------------- 25

4.5 Strengthening Element and Mechanical Analysis -------------------------------- 27

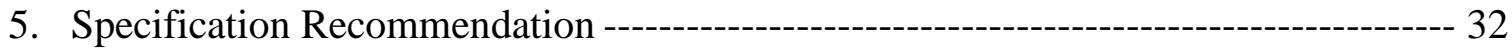

5.1 Recommended Specification ---o- 32

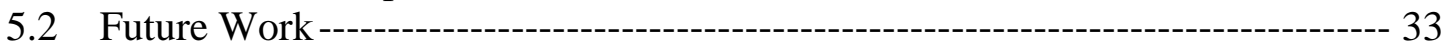

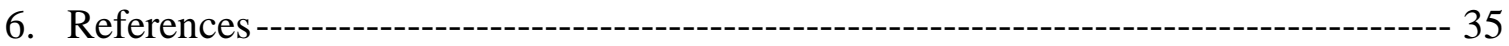

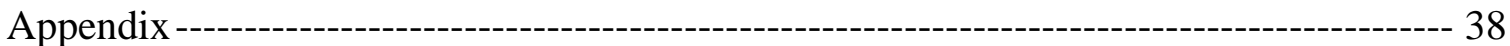

ASTM B 168 - 01, Standard Specification, Nickel-Chromium-Iron Alloys (UNS N06600, N06601, N06603, N06690, N06693, N06025, and N06045) and NickelChromium-Cobalt-Molybdenum Alloy (UNS N06617) Plate, Sheet, and Strip 
DEVELOPMENT OF A CONTROLLED MATERIAL SPECIFICATION FOR ALLOY 617 FOR NUCLEAR APPLICATIONS

\section{ACKNOLEDMENTS}

The authors greatly appreciate the Special Metals' providing historical chemistry data of Alloy 617 heats needed for this investigation. Thanks also go to Bill Corwin, Phil MacDonald and George Hayner for their constructive comments in reviewing this report. 


\section{BACKGROUND}

In selecting materials for construction of the Very High Temperature Reactors (VHTRs), Alloy 617 has been identified as one of the first priority candidates for applications in the temperature range of $760\left(1400^{\circ} \mathrm{F}\right)$ to $1,000^{\circ} \mathrm{C}\left(1832^{\circ} \mathrm{F}\right)$. The alloy offers a combination of high strength and oxidation resistance at high temperatures. Its properties make it an attractive material and often considered for use in aircraft and landbased gas turbines, chemical manufacturing components, metallurgical processing facilities, and power generation structures. Significant amount of data have been generated from the alloy for these applications since its development in the early 1970's. In addition to its attractive properties and availability of existing data, the major reason the alloy has been chosen lies in its closeness to acceptance into the American Society of Mechanical Engineers Boiler and Pressure Vessel Code (ASME B\&PV Code). In the mid-1980s, a draft Code Case for the design of Alloy 617 nuclear components was developed at a request of the Department of Energy (DOE) for the High-Temperature Gas-Cooled Reactor (HTGR) Program. The Case covered temperatures up to $950^{\circ} \mathrm{C}$, and was approved by the Subgroup on Elevated Temperature Design. Later, the Case was dropped from further consideration by the Code because the HTGR program was terminated. Information about the draft Case was summarized in a paper by Corum [1]. After the termination of the HTGR program, more applicable data on the alloy were generated in Germany [2].

Since the recent resumption of U. S. interest in developing nuclear reactors for electricity and hydrogen generation, Alloy 617 has regained great attention. Various plans and activities are underway to review its existing data, generate new data, and prepare it for final ASME B\&PV Code acceptance. Because of the intended unprecedented $1000^{\circ} \mathrm{C}\left(1832^{\circ} \mathrm{F}\right)$ working condition and 60 years of design life for the VHTR applications, product quality, high temperature properties, and behavior consistency of the material have become very important issues. Preliminary reviews of the material information reveal that the average high temperature strength is not ideal, but a possibility exists that better quality and behavior consistency may be assured through strictly specifying the material for nuclear applications. Furthermore, a refined specification, if developed properly, may provide improved behavior desired for the VHTR applications. Based on such expectations, a task has been identified under the Gen IV Materials Program to develop a refined specification within the standard specifications of the alloy with possibly above-average or improved material properties for data generation, examination, and qualification for the VHTR applications.

\section{THE MATERIAL AND SPECIFICATIONS}

Alloy 617, also designated as Inconel 617, UNS N06617, or W. Nr. 2.4663a, was initially developed for high-temperature applications above $800^{\circ} \mathrm{C}$. It is a nickelchromium-cobalt-molybdenum alloy with a good combination of high-temperature strength and oxidation resistance. The alloy also has excellent resistance to a wide range of corrosive environments, and it is readily formed and welded by conventional 
techniques. The chemical composition of Alloy 617 specified by the American Society for Testing and Materials (ASTM) is given in Table 1. The high $\mathrm{Ni}$ and $\mathrm{Cr}$ concentrations provide the alloy with great resistance to a variety of reducing and oxidizing environments. The $\mathrm{Al}$, in conjunction with the $\mathrm{Cr}$, offers oxidation resistance at high temperatures. In addition, the $\mathrm{Al}$ also forms intermetallic compound $\gamma^{\prime}$ (gamma prime) over a range of temperatures, which gives precipitation strengthening over solid solution strengthening imparted by the Co and the Mo. Strengthening is also derived from $\mathrm{M}_{23} \mathrm{C}_{6}, \mathrm{M}_{6} \mathrm{C}$, $\mathrm{Ti}(\mathrm{C}, \mathrm{N})$ and some other precipitates.

Table 1. ASTM Standard Specification for the Chemical Composition of Alloy 617

\begin{tabular}{|c|c|c|c|c|c|c|c|c|c|c|c|c|c|}
\hline Heat & Ni & Cr & Co & Mo & Fe & Mn & Al & C & Cu & Si & S & Ti & B \\
\hline Min & 44.5 & 20.0 & 10.0 & 8.0 & - & - & 0.8 & 0.05 & - & - & - & - & - \\
\hline Max & - & 24.0 & 15.0 & 10.0 & 3.0 & 1.0 & 1.5 & 0.15 & 0.5 & 1.0 & 0.015 & 0.6 & 0.006 \\
\hline
\end{tabular}

Besides the ASTM specification, Alloy 617 is also specified by several other organizations to reflect their particular needs and requirements. A summary of existing specifications of the alloy is given in Table 2. Generally, most specifications are originated from ASTM with little or no modifications. For boiler and pressure vessel applications, especially in nuclear constructions such as the VHTRs, ASME specifications are preferred due to their more stringent requirements germane to such applications. To conform to the ASME Boiler and Pressure Vessel Code, the product forms required for construction with alloy 617 must be incorporated into Section II, Part B. Often, the ASME specifications in Section II, Part B are identical with the corresponding ASTM specifications and, for those specifications where they differ, the

Table 2. Existing Specifications of Alloy 617

\begin{tabular}{|c|c|c|c|c|c|}
\hline Standard & Rod \& Bar & $\begin{array}{c}\text { Seamless } \\
\text { Pipe/Tube }\end{array}$ & $\begin{array}{c}\text { Welded } \\
\text { Pipe/Tube }\end{array}$ & Forgings & Plate \\
\hline ASME & SB-166 & $\begin{array}{c}\text { SB-167 } \\
\text { SB-444 CC }\end{array}$ & SB 546 & SB-564 & $\begin{array}{c}\text { SB-168 } \\
\text { SB-443 CC }\end{array}$ \\
\hline ASTM & B-166 & B-167 & B 546 & B-564 & B-168 \\
\hline SEA & AMS-5887 & - & - & AMS-5887 & AMS-5888 \\
\hline VdTÜV & 485 & 485 & - & 485 & 485 \\
\hline DIN & 17752 & - & 17751* & 17754 & 17750 \\
\hline ISO & - & 6207 & - & - & 6208 \\
\hline Standard & Sheet & Strip & Rings & Wire & \\
\hline ASME & $\begin{array}{c}\text { SB-168 } \\
\text { SB-443 CC }\end{array}$ & $\begin{array}{c}\text { SB-168 } \\
\text { SB-443 CC }\end{array}$ & - & SB 166 & \\
\hline ASTM & B-168 & B-168 & - & B-166 & \\
\hline SEA & AMS-5889 & AMS-5889 & AMS-5887 & - & \\
\hline VdTÜV & 485 & - & - & - & \\
\hline DIN & 17750 & 17750 & - & 17753 & \\
\hline ISO & 6208 & 6208 & - & 9724 & \\
\hline
\end{tabular}

* Reference did not indicate welded or seamless, welded assumed. 
exceptions are identified in a parenthetical statement on the title page. For Alloy 617, the ASTM and the ASME specifications have the same chemical composition requirements; however, the ASME specifications for particular product forms are slightly different from their ASTM counterparts in the deletion of the Supplementary Requirements for government procurement, addition of UNS N06617 heat treatment requirements, and mandate of certification.

\section{TASK ANALYSIS}

\subsection{Concerns for the Intended Applications}

Several concerns have emerged in reviewing the existing data for applications in the VHTRs. A review of the aforementioned draft Code Case, Code Case N-47-28 [3], indicates that the material offers limited strength for the VHTR designers at the temperatures of their interest. For example, at $982^{\circ} \mathrm{C}\left(1800^{\circ} \mathrm{F}\right)$ the expected minimum stress-to-rupture value for 100,000 hours is only $8 \mathrm{MPa}(1,110 \mathrm{psi})$. The values for some other temperatures of interest are presented in Table 3 (from Table I-14.6 of Code Case $\mathrm{N}-47-28)$.

Table 3. Expected Minimum Stress-to-Rupture Values, 1000 psi

\begin{tabular}{|c|c|c|c|c|c|c|}
\hline \multicolumn{2}{|c|}{ Temperature } & 10 & 100 & 1,000 & 10,000 & 100,000 \\
\hline${ }^{\circ} \mathrm{C}$ & ${ }^{\circ} \mathrm{F}$ & $\mathrm{h}$ & $\mathrm{h}$ & $\mathrm{h}$ & $\mathrm{h}$ & $\mathrm{h}$ \\
\hline 593 & 1100 & 70.14 & 61.79 & 52.85 & 43.54 & 34 \\
\hline 649 & 1200 & 58.65 & 49.59 & 40.12 & 30.59 & 21.72 \\
\hline 704 & 1300 & 47.33 & 37.81 & 28.36 & 19.78 & 12.5 \\
\hline 760 & 1400 & 36.44 & 27.05 & 18.68 & 12.12 & 7.57 \\
\hline 816 & 1500 & 26.5 & 18.22 & 11.79 & 7.35 & 4.51 \\
\hline 871 & 1600 & 18.3 & 11.85 & 7.39 & 4.52 & 2.76 \\
\hline 927 & 1700 & 12.24 & 7.64 & 4.69 & 2.85 & 1.75 \\
\hline 982 & 1800 & 8.12 & 5 & 3.02 & 1.84 & 1.11 \\
\hline
\end{tabular}

Note: The Code Case obtained did not include the values for $1000^{\circ} \mathrm{C}\left(1832^{\circ} \mathrm{F}\right)$.

In addition to the limited high temperature strength, reviews of the existing data further reveal that the material exhibits considerable scatter in mechanical properties. In a paper by Ennis et al. [4], specimens from three different heats were tested under 13.5 MPa $(93,000 \mathrm{psi})$ at $950^{\circ} \mathrm{C}\left(1742^{\circ} \mathrm{F}\right)$ in helium environment. The resulting creep curves indicate that creep strains of the three heats varied considerably at all times. At 20,000 hours, the difference reached a range from less than $1 \%$ to more than $8 \%$, as shown in Figure 1 . The grain sizes of the three heats were similar. It was speculated by the authors that this behavior difference might be attributed to the product forms as well as to the composition variations within the specification range. In another paper by Schubert et al. [5], it was reported that the scatter band widths for the $1 \%$ creep strain limit from tests at $800,850,900,950$ and $1000^{\circ} \mathrm{C}\left(1472,1562,1652,1742\right.$ and $\left.1832^{\circ} \mathrm{F}\right)$, respectively, were somewhat greater than $\pm 30 \%$. In this case, the tested heats were all from commercial or semi-commercial production, and no attempt was made to obtain 


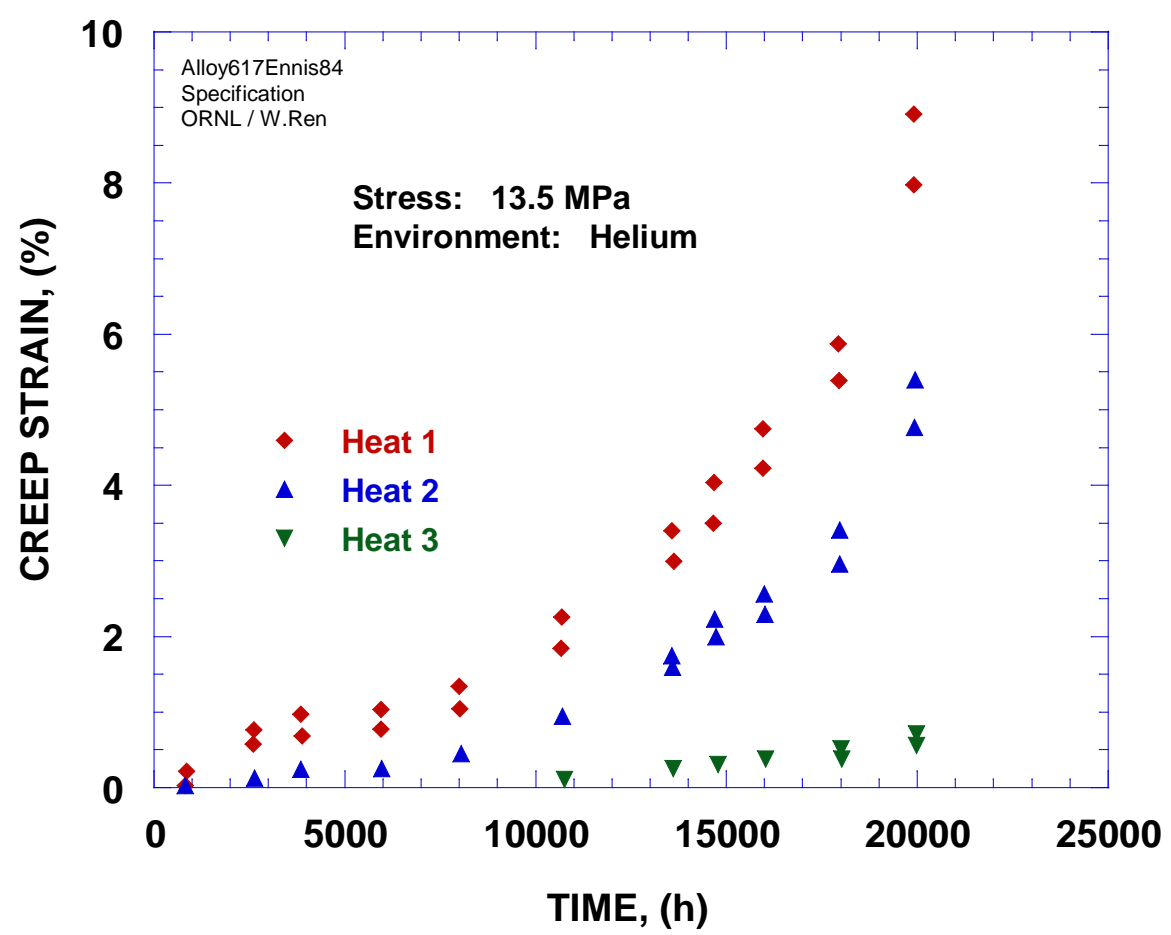

Figure 1. Typical Alloy 617 creep curves at $950^{\circ} \mathrm{C}\left(1742^{\circ} \mathrm{F}\right)$ reported by Ennis et al. [4]

special heats that would allow systematic investigation of compositional variations within the specification or of grain size effects. The data of $850^{\circ} \mathrm{C}\left(1562^{\circ} \mathrm{F}\right)$ are extracted from the paper and re-plotted in Figure 2. It can be observed from the plot that at the stress level around $50 \mathrm{MPa}(7.3 \mathrm{ksi})$, the time for 1\% creep strain scattered approximately two decades.

The limited strength at the temperatures of interest and the considerable scatter in the mechanical property data apparently place a significant challenge for the VHTR designers. To ensure design safety, the allowable design stresses must be established at levels much lower than the already limited strength values to include the considerable scatter and some other safety factors. Consequently, this would leave the designers even less available strength for the intended applications, as exhibited by the allowable stress intensity values in Table 4 (from Table I-14.4 of Code Case N-47-28). It can be seen in Table 4 that for 100,000 hours at $982^{\circ} \mathrm{C}\left(1800^{\circ} \mathrm{F}\right)$, only $3 \mathrm{MPa}(480 \mathrm{psi})$ is allowed although the expected minimum stress-to-rupture value is $8 \mathrm{MPa}(1,110 \mathrm{psi})$ as indicated in Table 3. All the other allowable stress intensity values are considerably lower than the expected minimum stress-to-rupture values. It should be noted that for the intended applications in VHTRs, a service temperature of up to 900 or $950^{\circ} \mathrm{C}\left(1652\right.$ or $\left.1742^{\circ} \mathrm{F}\right)$ or higher may be needed for a life time of 20 to 60 years (175,200 to 525,600 hours), depending on ease and cost of component replacement. This will obviously further lower the allowable stress intensity values as well as the expected minimum stress-to-rupture values. [Note: If the VHTR service temperature is finalized as $950^{\circ} \mathrm{C}\left(1742^{\circ} \mathrm{F}\right)$, 
DEVELOPMENT OF A CONTROLLED MATERIAL SPECIFICATION FOR ALLOY 617 FOR NUCLEAR APPLICATIONS

properties at $1000^{\circ} \mathrm{C}\left(1832^{\circ} \mathrm{F}\right), 50^{\circ} \mathrm{C}$ higher than the intended maximum application temperature, are still required for ASME Codification.]

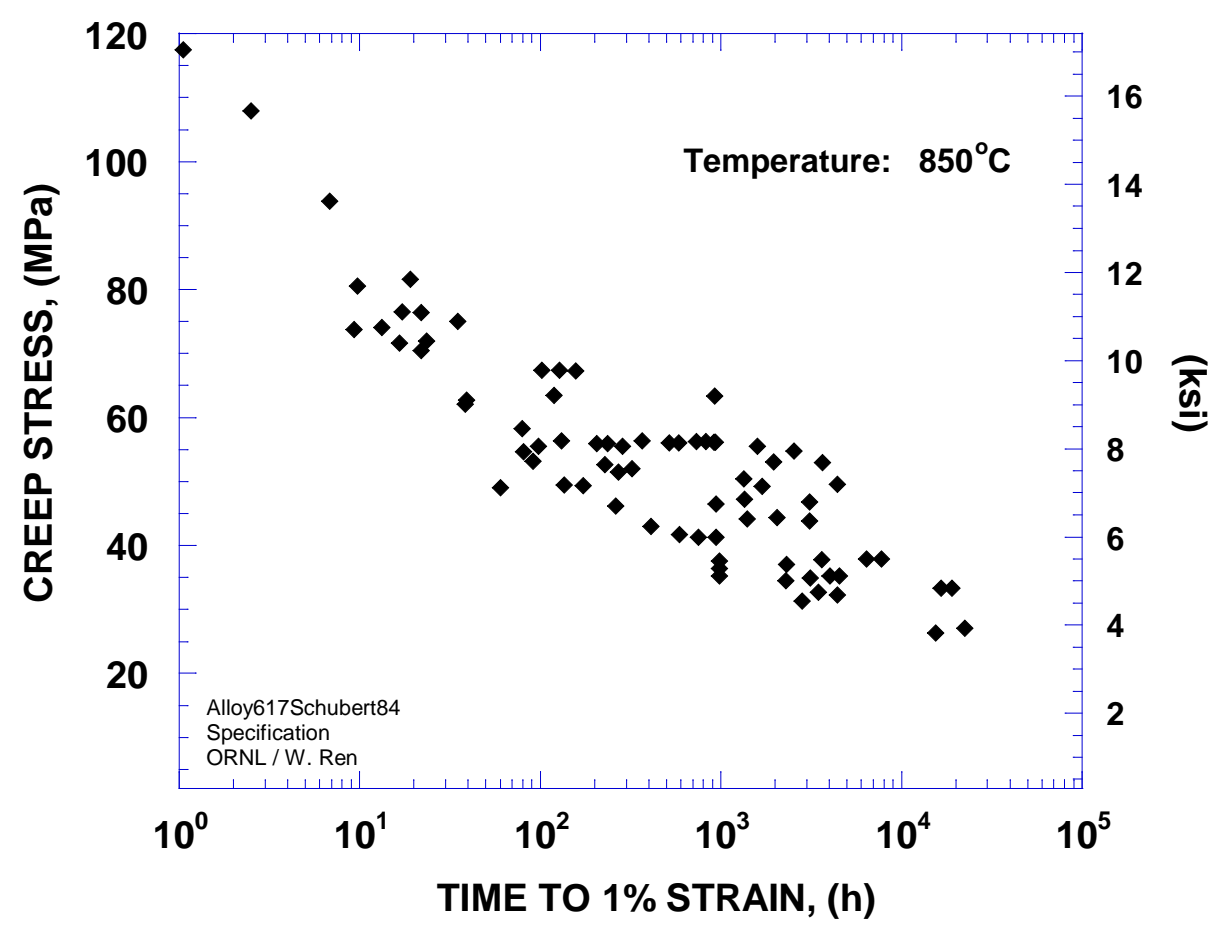

Figure 2. Alloy 617 creep data at $850^{\circ} \mathrm{C}\left(1652^{\circ} \mathrm{F}\right)$ reported by Schubert et al. [5]

Table 4. St - Allowable stress intensity values, $1000 \mathrm{psi}$

\begin{tabular}{|c|c|c|c|c|c|c|}
\hline \multicolumn{2}{|c|}{ Temperature } & \multirow{3}{*}{$\begin{array}{c}10 \\
\mathrm{~h} \\
35.7 \\
\end{array}$} & \multirow{3}{*}{$\begin{array}{c}100 \\
\mathrm{~h}\end{array}$} & \multirow{3}{*}{$\begin{array}{c}1000 \\
\mathrm{~h}\end{array}$} & \multirow{3}{*}{$\begin{array}{c}10,000 \\
\mathrm{~h}\end{array}$} & \multirow{3}{*}{ 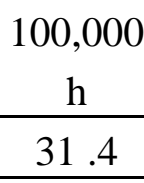 } \\
\hline & & & & & & \\
\hline 538 & 1000 & & & & & \\
\hline 593 & 1100 & 35 & 34 & 32.3 & 27 & 18 \\
\hline 649 & 1200 & 34.1 & 33.06 & 22 & 15 & 10.3 \\
\hline 704 & 1300 & 31.55 & 20 & 13 & 9.4 & 6.6 \\
\hline 760 & 1400 & 18 & 12 & 8.4 & 6 & 4.3 \\
\hline 816 & 1500 & 11.2 & 8.2 & 5.6 & 4 & 2.8 \\
\hline 871 & 1600 & 7.6 & 5.6 & 3.8 & 2.7 & 1.7 \\
\hline 927 & 1700 & 5.5 & 3.8 & 2.6 & 1.8 & 0.98 \\
\hline 982 & 1800 & 3.7 & 2.5 & 1.6 & 0.93 & 0.48 \\
\hline
\end{tabular}

Scatter in mechanical properties can usually be attributed to many factors including variations in testing standards, data processing methods, human error etc. For data generated from the same source, the reason most likely lies in the material per se. A 
review of the chemistry specification in Table 1 shows that some elements that may have effects on strengthening mechanisms and thus the resulting mechanical properties have "non-moderate" allowable ranges within the specified limits. In addition, the alloy is supplied in many product forms and processed by different finishing methods. These forms and methods can have significant effects on factors such as grain size and segregation, the variations of which can consequently scatter the mechanical properties. Factors that can affect properties also include melting methods, re-melting practices, and product size etc. Apparently, the standard specifications have given enough allowances to permit easy manufacturing of the material. However, for the unprecedented high temperature nuclear applications intended, these allowances may have consequently provided room for the observed data scatter that is hard to accept.

\subsection{Goals and Strategies}

Based on the above observations and experience from evolution and development of many other metallic materials, a possibility is considered to exist that the aforementioned concerns may be addressed through developing a refined specification within the limits of the ASTM/ASME standard specifications. Ideally, the refined specification should be attempted for the following four goals:

1) Narrowing the mechanical property data scatter band

2) Improving high temperature strength (tensile, creep, fatigue, creep-fatigue etc.)

3) Enhancing resistance to aging and/or environmental effects (carburization, decarburization, oxidation etc.)

4) Providing a unified and consistent material for different participants of the materials testing program

The first goal is attempted to improve behavior consistency and to raise the stress allowables. If a refined specification can be developed to narrow the scatter band of the stress-to-rupture data, for example, although the average expected minimum stress-torupture values may remain the same, the allowable stress intensity values can be increased, and higher design strength will become available for the reactor designers. Based on the speculation that some of the data scatter may result from variations in factors such as heat chemistry, grain size, heat treatment, product form and finishing method, the possibility exists that a refined specification may yield a narrowed data scatter band. To approach this goal, restricted requirements for concentrations of certain elements, grain size range, and heat treatments will be developed. However, it should be noted that the observed data scatter may also result from many other factors such as differences in testing practices, data reduction techniques, and even human error. These factors will certainly impose difficulties on data analysis for developing a refined specification.

The second and the third goals may be approached through optimizing the chemistry, grain size and heat treatment. However, it has to be realized that because the 
optimizations are confined within the limits of the standard specifications, the possibility of significant improvement in the desired properties is also limited. On the other hand, trade-offs are often unavoidable to balance among different property requirements such as creep, fatigue, environmental resistance, irradiation, etc. for a good overall performance.

The forth goal is straight-forwardly achievable. The refined specification resulting from the first three goals will be used for procurement of the alloy, and thus provide a unified and consistent material for different participants of the materials testing program.

In a standard specification, factors such as product forms, mechanical properties, dimensions and permissible variations, workmanship, finish, appearance, sampling, number of tests, specimen preparation, test methods, inspection, rejection, rehearing, certification, product marking, and some other supplementary requirements are usually stipulated in addition to chemistry, grain size, and heat treatment. In the present investigation, most of these factors will not be addressed for various reasons. For example, the product form, although may significantly affect properties, will not be discussed from the viewpoint of properties at this time because without detailed component structural designs the final product form needs are unknown. The mechanical properties will not be specified because they are the factors to be optimized and determined; and issues related to procurement can not be decided because they must be discussed with the vendors when the order is being placed. Generally speaking, most of these factors will remain as specified in the ASME standard specifications. Only a few factors such as the chemistry, grain size, and heat treatment etc. will be specified through this investigation.

The specification refining process will start from analysis of existing data and search for heats that exhibit above- and below-average properties. Then the chemical compositions, strengthening elements, and other related factors of these heats, along with results from a previous study on this topic, will be analyzed. Based on these analyses, a tentative refined specification will be recommended. This tentative specification will be discussed with vendors of Alloy 617 for their input, especially their capabilities to meet the requirements; and a small heat will be purchased for properties verification testing. Meanwhile, more detailed investigation plan will be developed if preliminary testing results suggest that such efforts be necessary.

\section{DATA ANALYSIS}

\subsection{Status of Mechanical and Chemical Data for Specification Analysis}

Although many properties, such as creep, fatigue, tensile, ductility etc., are important for the construction of the VHTRs, creep properties are the most concerned ones due to the required unprecedented service temperatures and design life. Therefore, the mechanical data analysis is mainly focused on the creep strength. 
DEVELOPMENT OF A CONTROLLED MATERIAL SPECIFICATION FOR ALLOY 617 FOR NUCLEAR APPLICATIONS

Table 5. Chemical compositions of the Alloy 617 heats used for high temperature creep strength analysis

\begin{tabular}{|c|c|c|c|c|c|c|c|c|c|c|c|c|c|c|c|c|}
\hline Heat & $\mathbf{N i}$ & $\mathrm{Cr}$ & Co & Mo & $\mathbf{F e}$ & Mn & Al & C & $\mathbf{C u}$ & Si & $\mathrm{S}$ & $\mathbf{T i}$ & $\mathbf{P}$ & B & $\mathbf{N}$ & Mg \\
\hline ASTM Min & 44.5 & 20.0 & 10.0 & 8.0 & & & 0.8 & 0.05 & & & & & & & & \\
\hline CCA 617Max & & 23.0 & 13.0 & 10.0 & 1.5 & 0.30 & 1.30 & 0.08 & 0.05 & 0.3 & 0.008 & 0.50 & 0.012 & 0.005 & 0.050 & \\
\hline CCA 617Min & Bal. & 21.0 & 11.0 & 8.0 & & & 0.80 & 0.05 & & & & 0.30 & & 0.002 & & \\
\hline CCA 617PA & Bal. & 21.5 & 11.3 & 8.6 & 0.7 & 0.03 & 1.24 & 0.06 & 0.01 & 0.1 & $<0.001$ & 0.39 & 0.003 & 0.003 & 0.013 & \\
\hline XX2857UK121 & 53.54 & 21.91 & 11.500 & 9.780 & 1.390 & 0.100 & 1.12 & 0.080 & & 0.090 & & 0.410 & & 0.002 & & \\
\hline XX00A1US & 53.91 & 22.51 & 12.67 & 8.91 & 0.13 & 0.04 & 1.05 & 0.07 & 0.23 & 0.04 & 0.007 & 0.41 & 0.003 & 0.0051 & & 0.029 \\
\hline XX00A2US & 54.6 & 22.77 & 12.72 & 8.59 & 0.18 & 0.02 & 0.98 & 0.07 & 0.01 & 0.04 & 0.008 & 0.25 & 0.002 & 0.005 & 0.019 & 0.022 \\
\hline XX00A4US & 54.73 & 22.31 & 12.46 & 9.09 & 0.15 & 0.02 & 1.06 & 0.07 & 0.01 & 0.08 & 0.007 & 0.35 & 0.003 & 0.0043 & 0.012 & 0.029 \\
\hline XX00A5US & 55.91 & 21.77 & 12.24 & 8.71 & 0.19 & 0.03 & 0.99 & 0.07 & 0.02 & 0.06 & 0.007 & 0.46 & 0.003 & 0.0059 & 0.011 & 0.024 \\
\hline XX05A4UK & 54.97 & 22.04 & 12.46 & 9 & 0.24 & 0.02 & 1.08 & 0.07 & 0.07 & 0.12 & 0.002 & 0.43 & 0.006 & 0.002 & & 0.043 \\
\hline XX05A7UK & 55.02 & 21.77 & 12.57 & 9.15 & 0.21 & 0.01 & 1.07 & 0.06 & 0.07 & 0.14 & 0.004 & 0.51 & 0.004 & 0.002 & & 0.051 \\
\hline XX07A7UK & 55.12 & 21.99 & 12.3 & 8.52 & 0.52 & 0.02 & 1.31 & 0.08 & 0.09 & 0.14 & 0.003 & 0.43 & 0.004 & 0.001 & & 0.07 \\
\hline XX09A4UK & 55.11 & 21.83 & 12.55 & 8.79 & 0.38 & 0.02 & 1.15 & 0,07 & & 0.1 & 0.001 & & & & & \\
\hline XX18A4UK & 54.22 & 21.86 & 12.35 & 8.95 & 0.72 & 0.01 & 1.03 & 0.051 & 0.09 & 0.17 & 0.006 & 0.28 & 0.001 & 0.003 & & 0.03 \\
\hline XX20A5UK & 55.61 & 21.32 & 12.67 & 8.85 & 0.28 & 0.01 & 1.05 & 0.06 & 0.1 & 0.15 & 0.001 & 0.27 & 0.002 & 0.002 & & 0.021 \\
\hline XX26A8UG & 54.54 & 21.89 & 12.48 & 9 & 0.48 & 0.03 & 1.17 & 0.06 & & 0.09 & 0.001 & 0.26 & 0.001 & 0.002 & & 0.039 \\
\hline XX41A7UK & 54.01 & 21.42 & 12.9 & 8.83 & 1.35 & 0.02 & 0.92 & 0.06 & 0.04 & 0.19 & 0.001 & 0.3 & 0.002 & 0.001 & & 0.051 \\
\hline XX63A8UK & Bal. & 22.30 & 12.10 & 9.27 & 1.02 & 0.06 & 1.07 & 0.07 & 0.09 & 0.19 & 0.001 & 0.37 & & 0.003 & & \\
\hline XX63А8UK & Bal. & 21.8 & 11.8 & 9.3 & 0.93 & 0.049 & 0.92 & 0.075 & 0.092 & 0.19 & & 0.39 & & 0.005 & & \\
\hline
\end{tabular}

a) Composition from Product Analysis of CCA heat. $0.02 \% \mathrm{Nb}$ was also found in the analysis but not listed in the table.

b) Composition from Heat Analysis of XX2857UK121 heat after VIM melting and ESR re-melting. 0.210\% Nb heat was also found in the analysis but not listed in the table. 
DEVELOPMENT OF A CONTROLLED MATERIAL SPECIFICATION FOR ALLOY 617 FOR NUCLEAR APPLICATIONS

Table 6. Chemical Compositions of Heats for Variant Alloy 617

\begin{tabular}{|c|c|c|c|c|c|c|c|c|c|c|c|c|c|}
\hline Heat & $\mathbf{N i}$ & $\mathrm{Cr}$ & Co & Mo & Fe & Mn & Al & C & $\mathbf{C u}$ & Si & S & $\mathbf{T i}$ & B \\
\hline ASTM Min & 44.5 & 20.0 & 10.0 & 8.0 & & & 0.8 & 0.05 & & & & & \\
\hline ASTM Max & & 24.0 & 15.0 & 10.0 & 3.0 & 1.0 & 1.5 & 0.15 & 0.5 & 1.0 & 0.015 & 0.6 & 0.006 \\
\hline 492 & Bal. & 22.74 & 12.10 & 9.43 & 0.07 & 0.03 & 0.04 & 0.059 & & 0.07 & & 1.98 & \\
\hline 493 & Bal. & 16.19 & 12.21 & 9.26 & 0.03 & 0.03 & 0.05 & 0.051 & & 0.07 & & 1.75 & \\
\hline 494 & Bal. & 12.44 & 12.22 & 9.03 & 0.03 & $<0.01$ & 0.03 & 0.066 & & 0.06 & & 1.79 & \\
\hline 800 & Bal. & 22 & 12 & 9 & & & 0.1 & 0.0904 & & & & 2 & \\
\hline 801 & Bal. & 22 & 12 & 9 & & & 0.5 & 0.0869 & & & & 2 & \\
\hline 802 & Bal. & 22 & 12 & 9 & & & 0.1 & 0.0863 & & & & 1 & \\
\hline 803 & Bal. & 22 & 12 & 9 & & & 0.5 & 0.0860 & & & & 1 & \\
\hline 804 & Bal. & 16 & 12 & 9 & & & 0.5 & 0.0908 & & & & 1 & \\
\hline 805 & Bal. & 12 & 12 & 9 & & & 0.5 & 0.0917 & & & & 1 & \\
\hline
\end{tabular}

Note: Except for carbon, the compositions listed for the 800 series are aim values. 
A fairly large amount of mechanical properties data have been collected for the Gen IV materials program. However, to conduct analysis for refining specification, the mechanical properties data must be coupled with their heat chemical composition data and much other information that affects the properties. Unfortunately in many cases such matching information is not available. Mechanical properties data are often found without their heat chemistry information and vice versa. Furthermore, because most of the existing data were generated for other purposes, they lack the well designed systematical variations required for the specification refinement analysis.

Despite the overall unsatisfactory status of the available information, data from approximately 300 creep tests on 29 heats have been selected and extracted for the analysis. Among the 29, most heats were commercial products, and were tested for mechanical properties without chemical modification by the investigators. Chemical compositions of these heats are listed in Table 5. Heats with chemical modifications by the investigators are listed in Table 6.

Under the header row of Table 5, the first and the second rows are the ASTM standard specification chemistry from Table 1 listed here as a baseline for comparison. They are adopted by the ASME standard specifications without modification. The third and the fourth rows are the upper and the lower limits of a controlled chemistry version of the alloy designated as CCA 617 or Marco 617 produced by ThyssenKrupp VDM. The CCA 617 specification was developed for applications in the THERMIE project. It is included for this analysis based on a suggestion from its vendor and preliminary testing results at the Oak Ridge National Laboratory (ORNL) that it may offer improved creep strength due to its further controlled chemical composition. As shown in the table, all the controlled concentrations exhibited in red fall within the ASTM standard specification limits. The fifth row, CCA 617 PA, lists the product analysis (check analysis) chemistry of the CCA heat used for generating the creep rupture stress data employed in the present investigation. The sixth row is the heat analysis composition of Heat XX2857UK121 produced by the Special Metals. Personal communications with the Special Metals suggest that its relatively high Mo and C concentrations (still within the ASTM standard chemistry specification limits) may provide enhancement to its creep properties. The rest of the rows in Table 5 are heats produced by the Special Metals (or its predecessor the Huntington Alloys) in the 1970's. Most of these heats were used in developing Code stresses of Alloy 617.

The chemical compositions in Table 5 are complicated by melting method employed in producing these heats. Heats designated with "US" indicate that air melting method was employed; those with "UK" indicate vacuum induction melting practice (VIM) followed by electro slag re-melting (ESR); and the one with "UG" suffix indicates air melting followed by ESR. Documented personal communications with the Special Metals suggest that for heats with the "UK" suffix, levels for C, S, Al, Ti and Mo produced before 1978 were determined from the ESR re-melted ingot, except Heat XX41A7UK produced in 1979 with its Mo measured only before the ESR. The levels of the remaining elements were measured from the VIM ladle, i. e., from heat analysis. It is further suggested that levels for elements other than $\mathrm{C}, \mathrm{S}, \mathrm{Al}, \mathrm{Ti}$ and Mo might have 
changed as a result of ESR. The Mg levels, for example, would have been reduced significantly after ESR. The Mg levels available and shown in Table 5 are the levels determined before ESR. It is anticipated by the Special Metals that the reduction in $\mathrm{Mg}$ levels was on the order of about $50 \%$ as a result of ESR; and that in $\mathrm{Al}$ was on the order of $10 \%$. This means that for the "UK" heats listed in Table 5 , only the chemical levels for $\mathrm{C}, \mathrm{S}, \mathrm{Al}, \mathrm{Ti}$ and Mo are relatively accurate; the rest of the elements, highlighted in the table, may actually have lower or much lower levels than the values available and presented.

In addition to the complications described above, measurements of the same heat conducted by different institutes also show different results. Two heats in Table 5, XX14A6UK and XX63A8UK, are presented with chemistries measured by different sources. The rows in italics are compositions measured by General Electric (GE) prior to mechanical testing, while the rows in regulars are compositions certified by the vendor when the material was supplied.

It is apparent that although chemistries of many heats that can be coupled with mechanical property data have been collected as presented in Table 5, reliable data that can be used for analysis are actually quite limited. This limited information is further impaired by the fact that some crucial factors such as product forms, grain sizes, and heat treatment conditions are mostly unknown. Because these heats were produced some 20 to 30 years ago, attempts to retrieve such information including intensive communications with the manufacturer ended up fruitless. The manufacturer indicated that they "do not have records documenting grain size, annealing temperature or time from this long ago and will not be able to provide this information” [6].

\subsection{Mechanical Property Analysis}

Although the complication of chemical composition data makes the analysis difficult, it is clear from Table 5 that the chemistry of Alloy 617 can vary quite noticeably from heat to heat within the ASTM standard specification. Therefore, a key question that needs to be answered is whether products from these heats exhibit differences in mechanical behavior, especially creep resistance in the temperature range of interest to the VHTR applications. If certain heats can demonstrate the desired "above-average" behavior, efforts can then be focused on analyzing their chemistries and processing methods to provide guidance for refining the specification.

To evaluate the mechanical behavior, creep rupture stresses of various heats available at $649^{\circ} \mathrm{C}\left(1200^{\circ} \mathrm{F}\right)$ and $871^{\circ} \mathrm{C}\left(1600^{\circ} \mathrm{F}\right)$ are presented in Figures 3 and 4, respectively. Slight differences in relative creep strength among the heats can be observed. However, because not all the heats were tested at each temperature, as shown in the figures, a comparison based solely on data available at a given temperature such as those in Figure 3, or in Figure 4, would be biased due to the lack of a common baseline when strengths at different temperatures are considered. 
DEVELOPMENT OF A CONTROLLED MATERIAL SPECIFICATION FOR ALLOY 617 FOR NUCLEAR APPLICATIONS

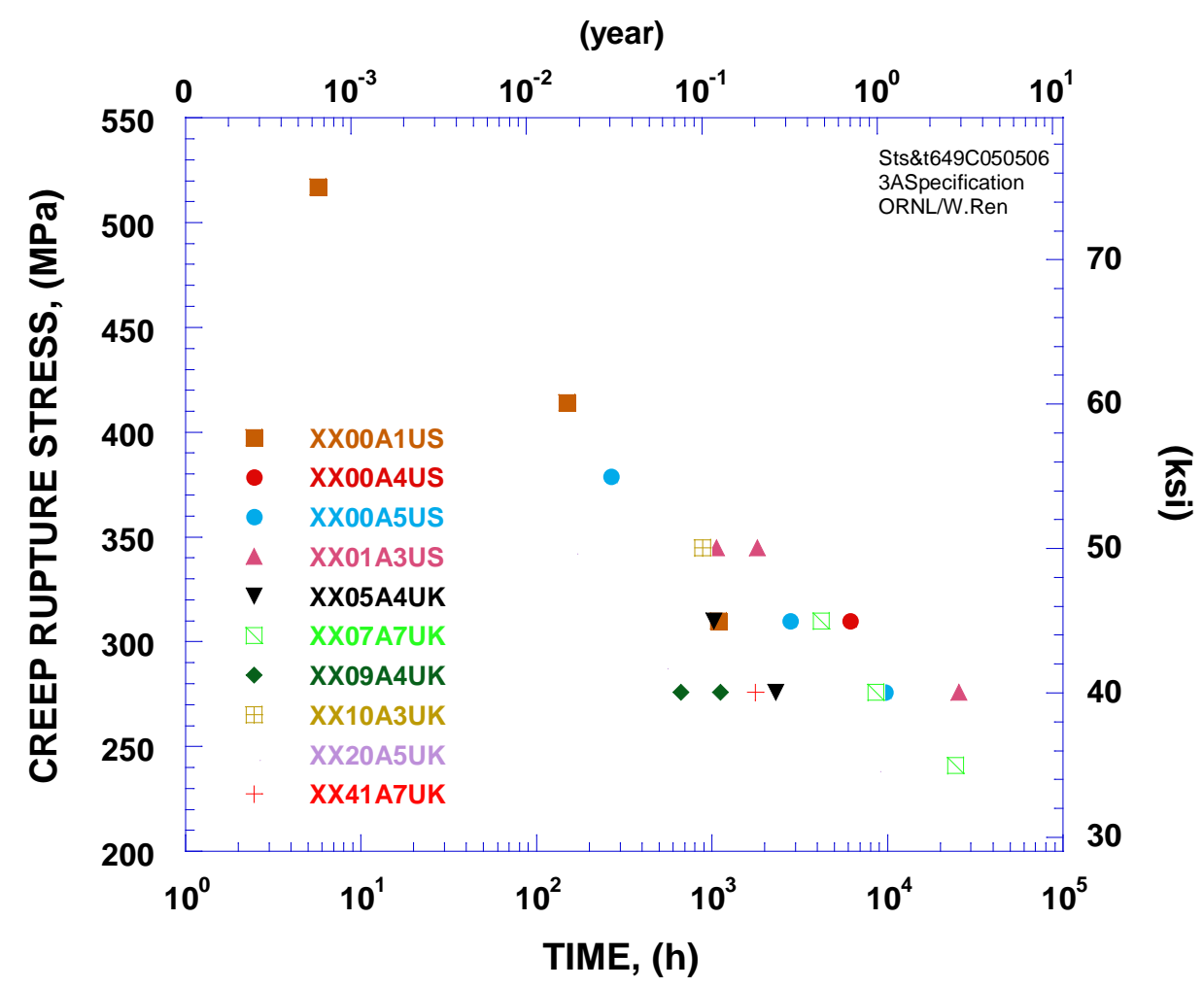

Figure 3. Creep rupture stresses of various heats available for $649^{\circ} \mathrm{C}\left(1200^{\circ} \mathrm{F}\right)$

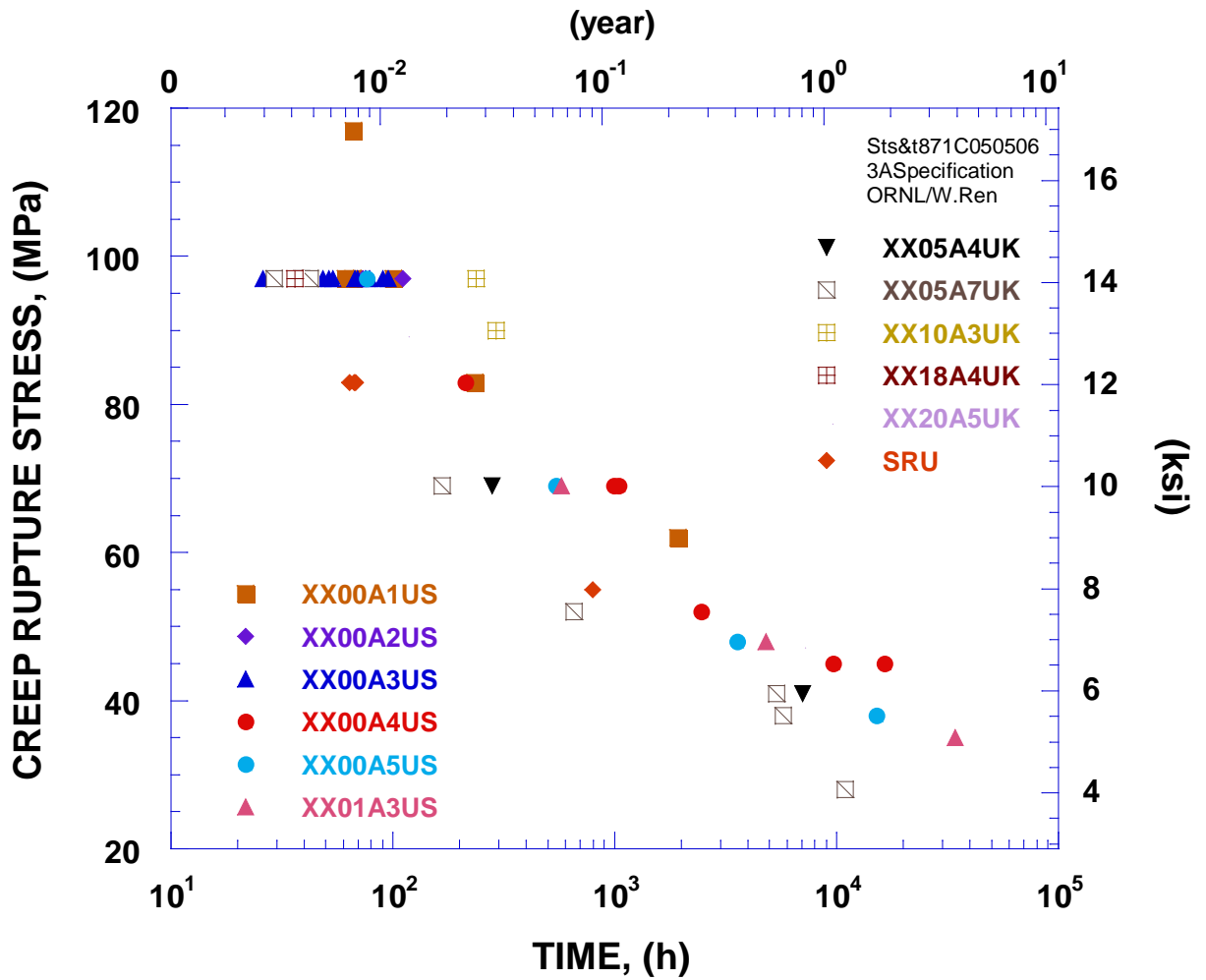

Figure 4. Creep rupture stresses of various heats available for $871^{\circ} \mathrm{C}\left(1600^{\circ} \mathrm{F}\right)$ 
To search for the above-average behavior, the comparison must be conducted on a common basis that represents the AVERAGE behavior at different temperatures and stresses. Because the purpose is to identify properties above the average currently suggested for design, the heats that provided the basis for developing Code stresses were selected and their creep data were used to establish the common baseline. In extracting the average behavior, the creep rupture stresses vs. times data of these heats at various temperatures were first processed into a master curve for the Larson-Miller Parameter as shown in Figure 5. Then the master curve was represented by a polynomial developed through least-squares fit of the data. Because the master curve polynomial contains information from various temperatures, average creep rupture stress vs. time at any temperature range, even those without sufficient existing data, can be calculated to provide the basis for the comparison.

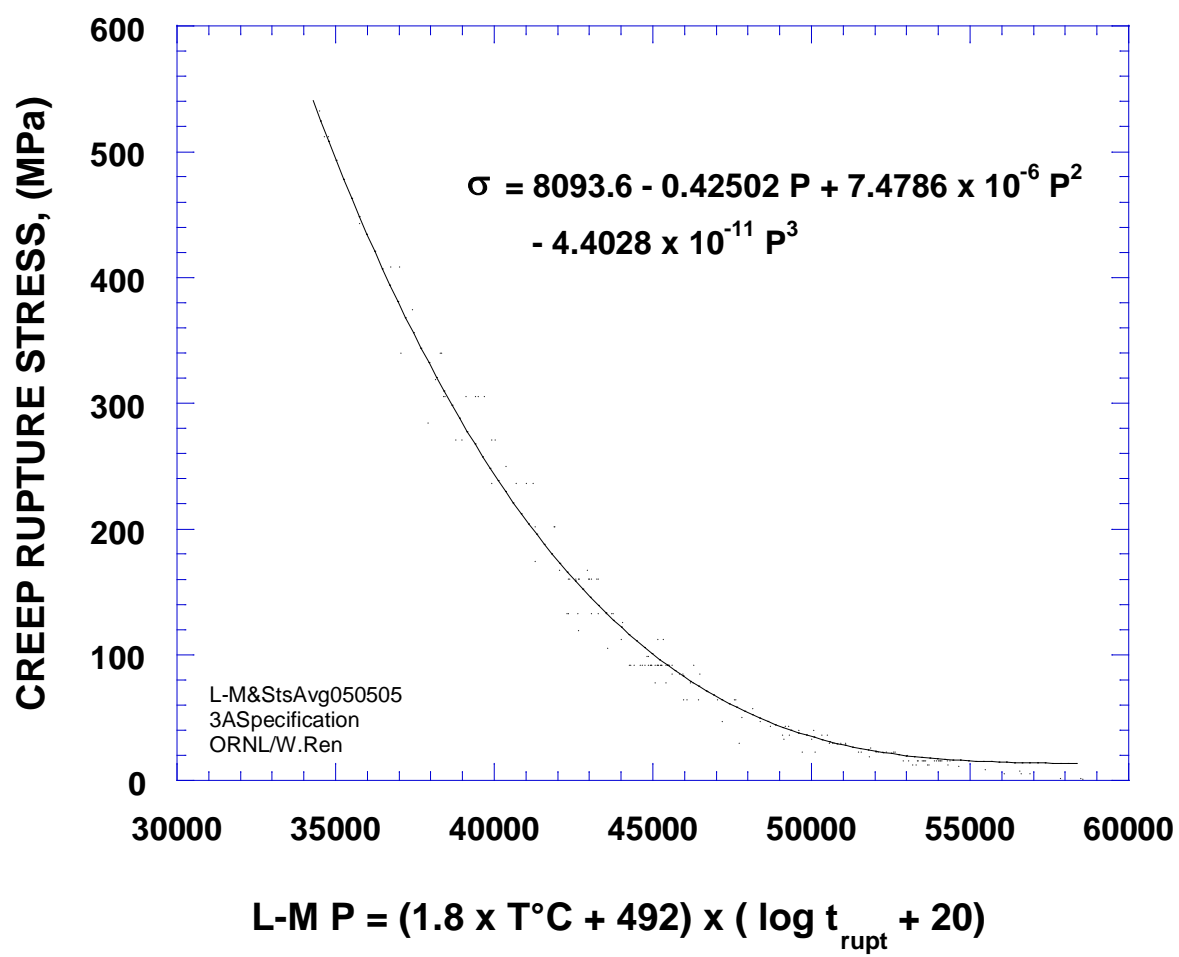

Figure 5. Master curve for Larson-Miller Parameter of creep data from heats used for the development of Code stresses

With the average strength curve calculated from the master Larson-Miller Parameter polynomial as the common baseline, creep rupture stresses of the heats available for $760^{\circ} \mathrm{C}\left(1400^{\circ} \mathrm{F}\right)$ are compared as an example shown in Figure 6, in which the difference between a creep rupture stress data point and the average creep strength curve can be measured. This difference is then expressed in percentage deviation for further analysis.

The percentage deviations of various heats at all temperatures are divided into three groups. The first group includes five heats with relatively higher-than-average creep 
strength: XX00A1US, XX00A4US, XX01A3US, XX14A6UK, and CCA 617. The second group is composed of four heats with relatively lower-than-average creep strength: XX07A7UK, XX05A7UK, XX20A5UK, and XX63A8UK. The rest falls into the third group that consists of heats either of average creep strength, or of significant data scatter, or without sufficient data points for a confident rating.

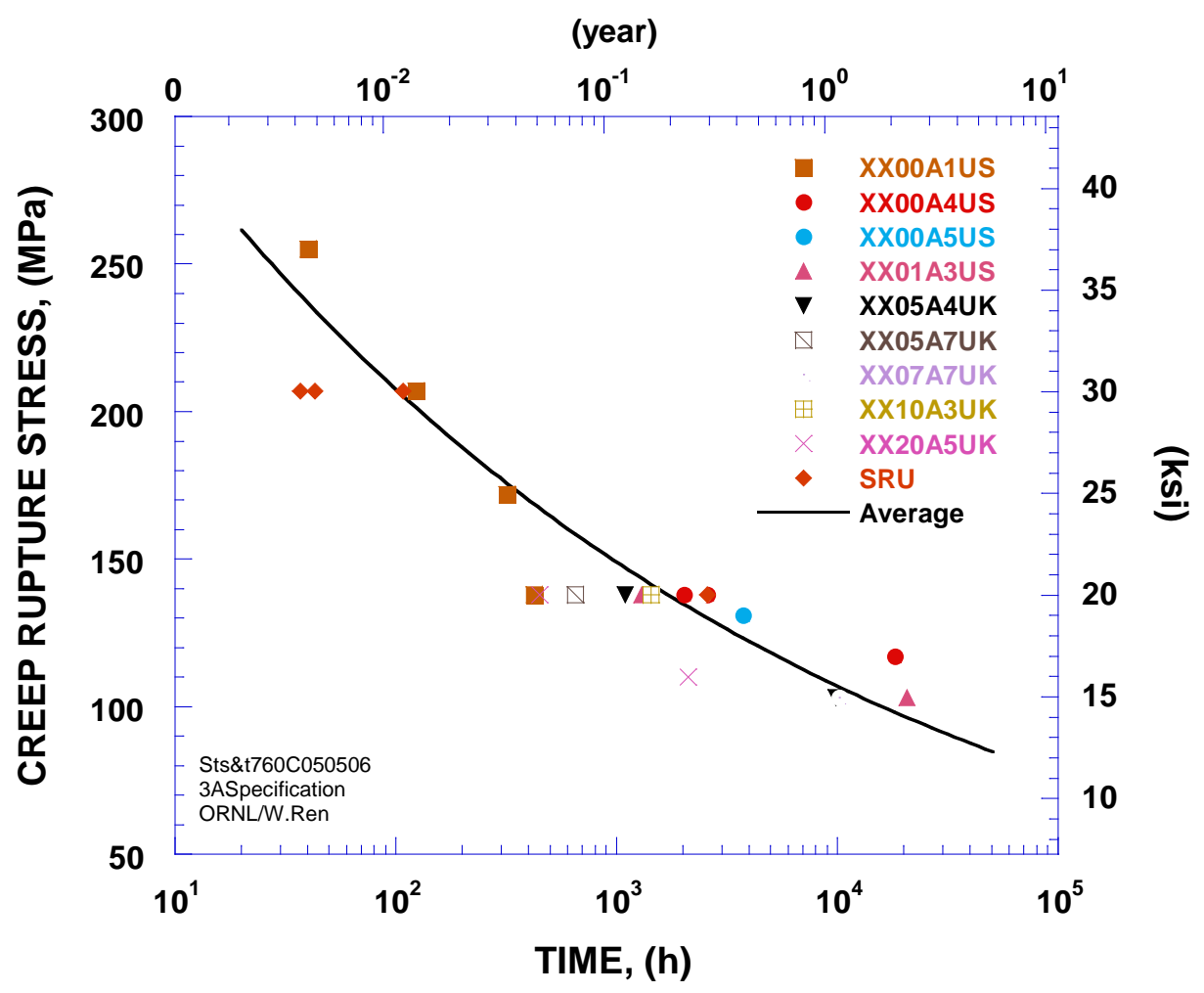

Figure 6. Comparison of creep rupture stresses of various heats to average creep strength at $760^{\circ} \mathrm{C}\left(1400^{\circ} \mathrm{F}\right)$. (Only heats with data available at the temperature are displayed.)

Three representative heats from the first group are presented in Figures 7 to 9 . Figure 7 shows the creep rupture stress deviation of the CCA 617 heat. At $700^{\circ} \mathrm{C}\left(1292^{\circ} \mathrm{F}\right)$, the highest creep rupture stress is about $50 \%$ higher than the average. However, the strength drops down to the average level as temperature approaches $800^{\circ} \mathrm{C}\left(1472^{\circ} \mathrm{F}\right)$, and no data are available at higher temperatures. Figure 8 shows the creep rupture stress deviation of Heat XX14A6UK. The data exhibit its highest creep rupture stresses in the temperature range of 950 to $1050^{\circ} \mathrm{C}\left(1742\right.$ to $\left.1922^{\circ} \mathrm{F}\right)$. However, scattering below the average is also observed in one data point in this temperature range. Figure 9 shows the creep rupture stress deviation of Heat XX00A4US. The entire data set demonstrates a steady higherthan-average trend up to nearly $1000^{\circ} \mathrm{C}\left(1832^{\circ} \mathrm{F}\right)$. Again, scatter is observed and one data point falls obviously below the average. 
DEVELOPMENT OF A CONTROLLED MATERIAL SPECIFICATION FOR ALLOY 617 FOR NUCLEAR APPLICATIONS

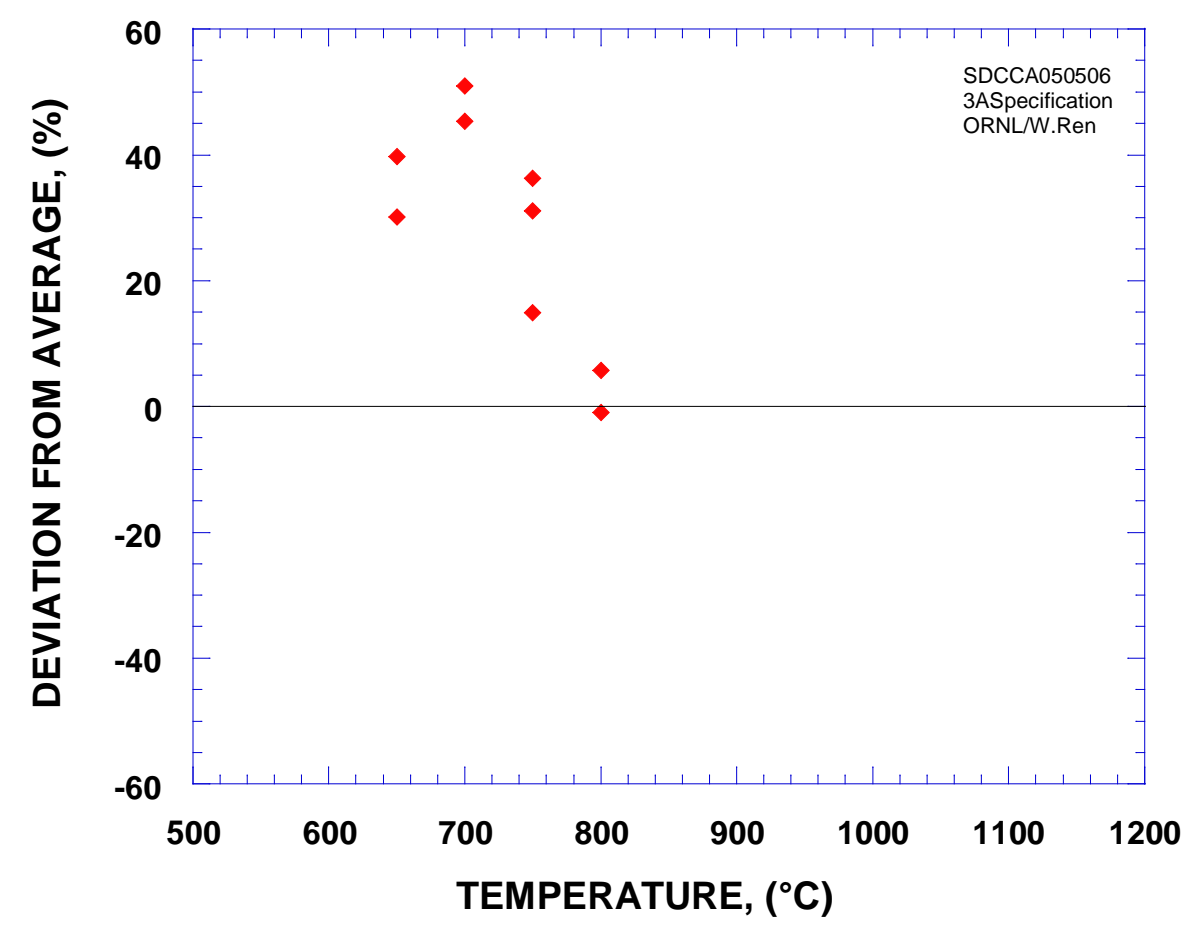

Figure 7. Creep rupture stress deviation of CCA 617 from the average creep strength at various temperatures

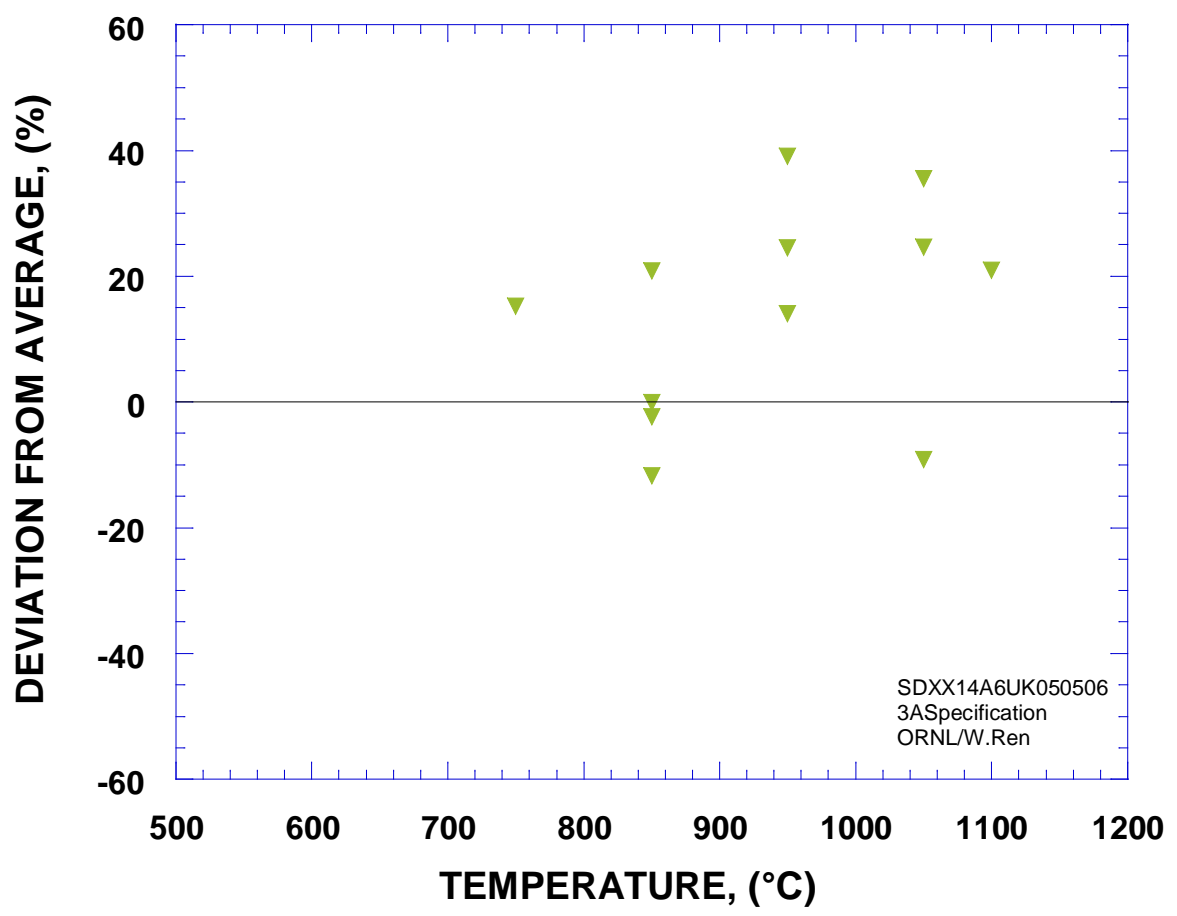

Figure 8. Creep rupture stress deviation of Heat XX14A6UK from the average creep strength at various temperatures 


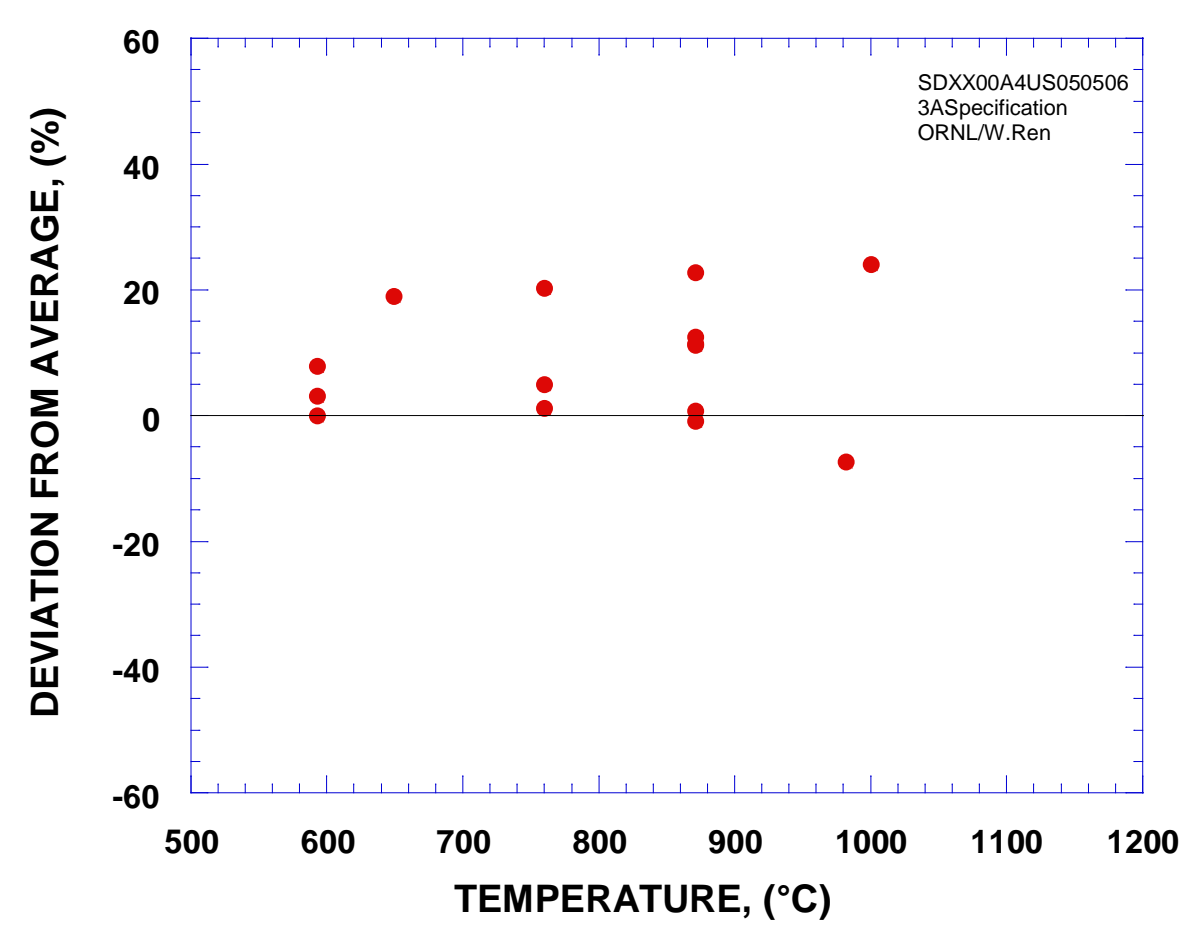

Figure 9. Creep rupture stress deviation of Heat XX00A4US from the average creep strength at various temperatures

It should be pointed out that although the first group has the above-average creep strength, each of the five heats has exhibited data point or points close to or below the average level. Therefore, from design viewpoint, none of these heats should be considered to have significantly higher creep strength than the average. The analysis only indicates that these heats have statistically higher creep strength than the average level. However, it suggests that some heats may have the desired above-average creep strength in certain temperature range, as is observed in Figure 7 for the CCA 617 heat. The decrease of creep strength in the CCA 617 with temperature, or with time at given temperatures, can be alternatively observed in its Larson-Miller Parameter as shown in Figure 10.

Two representative heats from the second group are presented in Figures 11 and 12. Figure 11 shows the creep rupture stress deviation of Heat XX05A7UK. Its creep strength is constantly lower than the average level except one scattered point at $1000^{\circ} \mathrm{C}$ $\left(1832^{\circ} \mathrm{F}\right)$. Figure 12 shows the creep rupture stress deviation of Heat XX07A7UK. The heat exhibits higher-than-average creep strength at temperatures up to about $700^{\circ} \mathrm{C}$ $\left(1292^{\circ} \mathrm{F}\right)$ and then a continuous decrease to approximately $40 \%$ less than the average around $1100^{\circ} \mathrm{C}\left(2012^{\circ} \mathrm{F}\right)$. Again, scatter is observed in all heats in the second group. 
DEVELOPMENT OF A CONTROLLED MATERIAL SPECIFICATION FOR ALLOY 617 FOR NUCLEAR APPLICATIONS

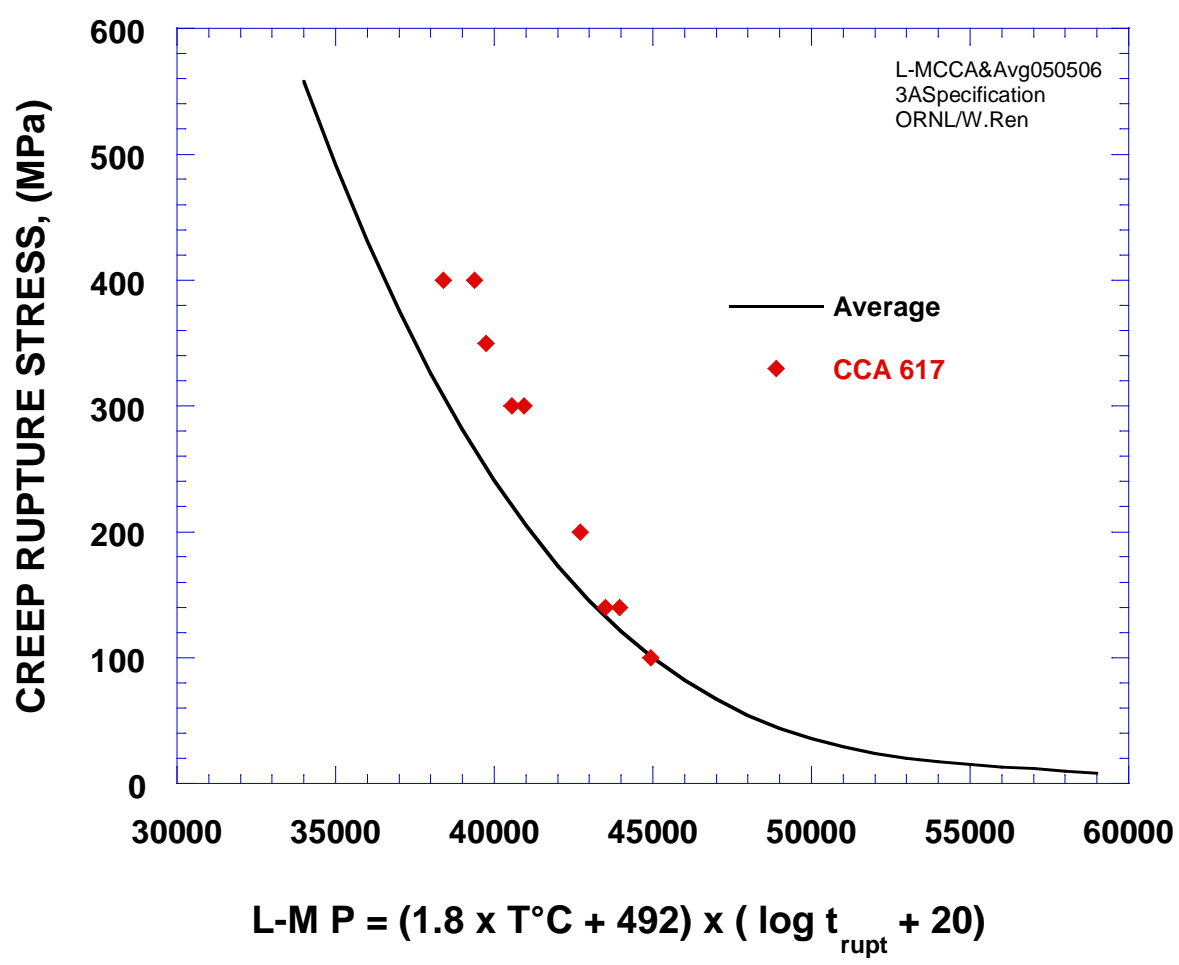

Figure 10. Comparison of CCA 617 and the average creep strength in Larson-Miller Parameter

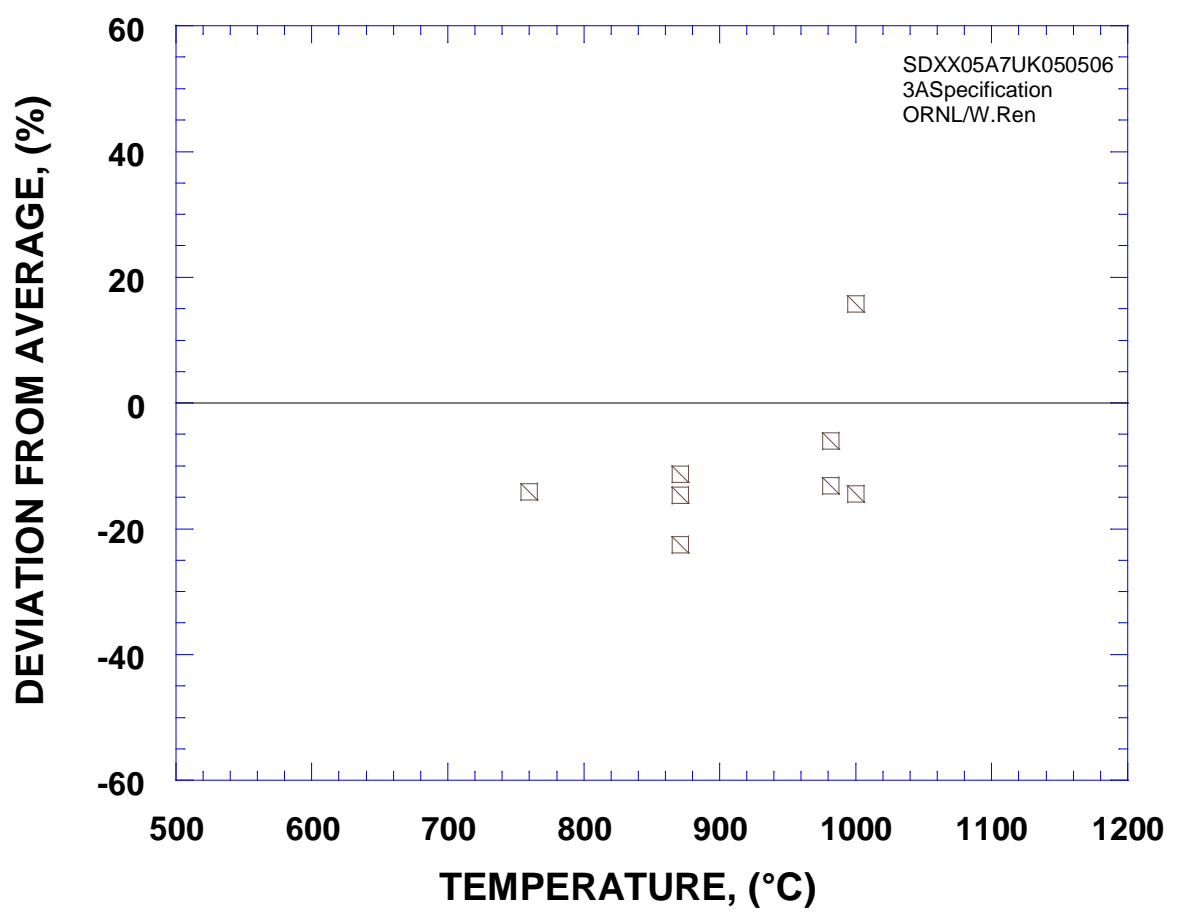

Figure 11. Creep rupture stress deviation of Heat XX05A7UK from the average creep strength at various temperatures 
DEVELOPMENT OF A CONTROLLED MATERIAL SPECIFICATION FOR ALLOY 617 FOR NUCLEAR APPLICATIONS

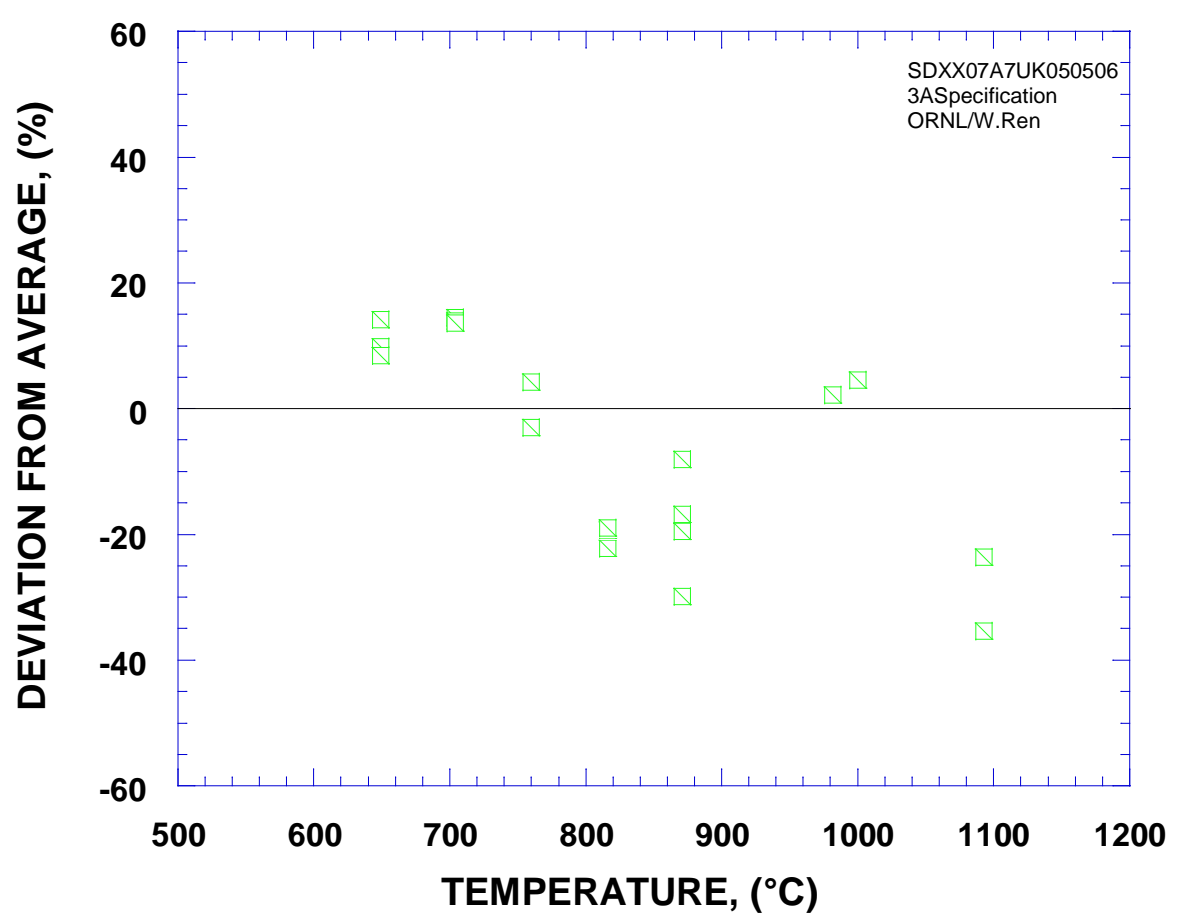

Figure 12. Creep rupture stress deviation of Heat XX07A7UK from the average creep strength at various temperatures

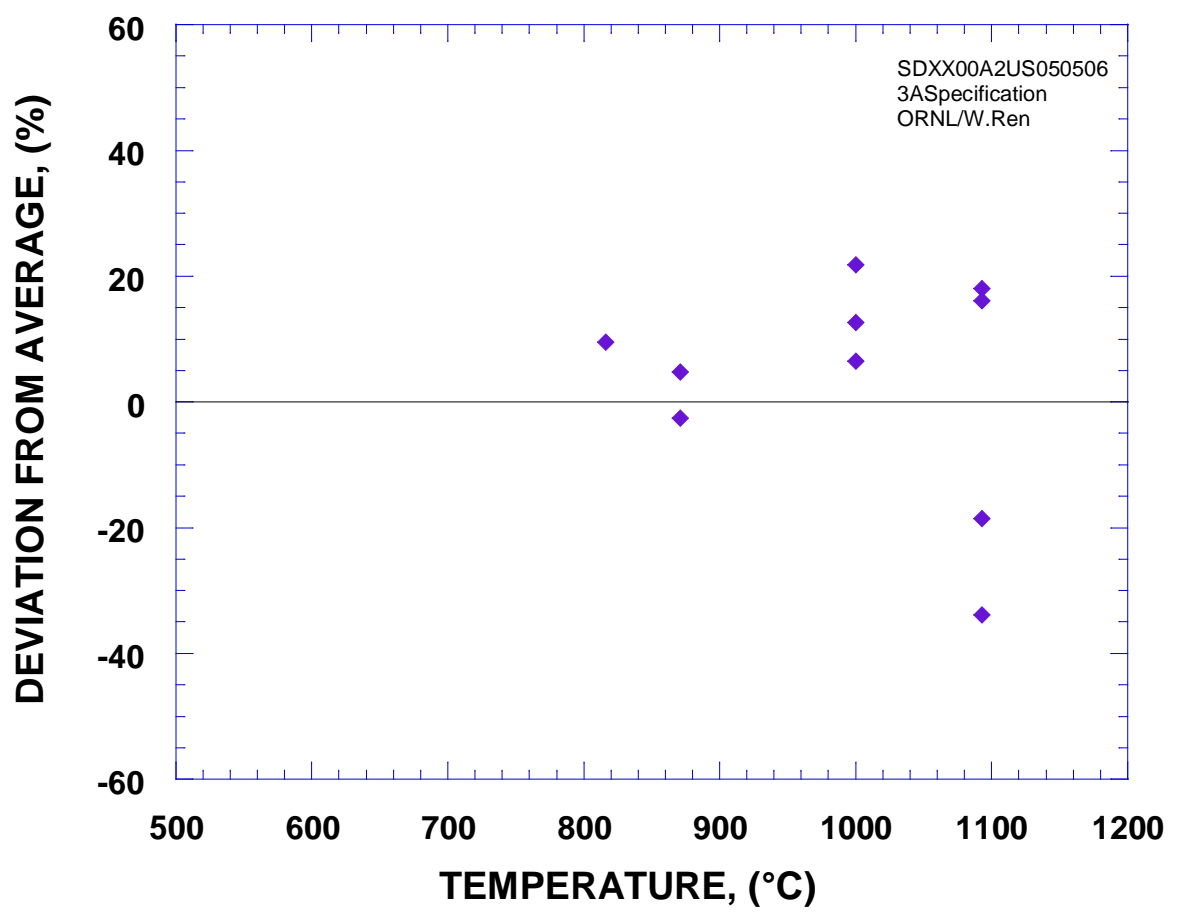

Figure 13. Creep rupture stress deviation of Heat XX00A2US from the average creep strength at various temperatures 
One representative heat from the third group, Heat XX00A2US, is presented in Figure 13. It can be observed that its creep rupture stress data scatter from nearly $40 \%$ lower than the average level to about $20 \%$ higher.

The aforementioned Heat XX2857UK121 produced by the Special Metals with relatively high $\mathrm{Mo}$ and $\mathrm{C}$ concentrations has not been included in the above analysis because no creep data are available and detailed specification information could not be released by the vendor due to its customer order proprietary nature. However, some material from this heat has been provided to ORNL. Specimens have been made and creep testing is in progress. For the time being, creep data from several other heats with said similar material conditions have been provided by the Special Metals, and these data were used in the above analysis with the designation of SRU. However, as observed in Figures 3 and 6, the SRU data fell into the third group for their demonstrated average creep strength.

\subsection{Chemical Composition Analysis}

To search for a refined chemistry specification, compositions of the heats that have exhibited creep strength higher or lower than the average are analyzed. Based on the strengthening mechanisms of Alloy 617, the analysis is mainly focused on elements that are considered most important to the creep strength. For heats with more than one composition measurements, XX14A6UK and XX63A8UK, the measurements directly prior to mechanical testing are used in the analysis.

Figure 14 shows the concentrations of $\mathrm{Ti}$ in various heats. The heats with an " $\mathrm{H}$ " prefix are the first group heats with higher-than-average creep strength; while those with an "L" prefix are the second group heats with lower-than-average creep strength. The rest belongs to the third group. For the three heats at the bottom, no data on the $\mathrm{Ti}$ concentration were reported in the composition tables obtained. It can be observed in Figure 14 that the " $H$ " heats are located between 0.33 to $0.43 \%$. However, an "L" heat, XX63A8UK and a third group heat, XX00A3US, are also found in this range. A review of available information indicates that the creep data for both the "L" heat, XX63A8UK, and the " $\mathrm{H}$ " heat next to it, XX14A6UK, were generated by the same institute, GE. Therefore, the same testing method and standard should have been employed and the data reduction procedures should be considered consistent. This should have excluded the possibility of scatter resulting from difference in testing and data processing. However, in Heat XX14A6UK the grain size was ASTM \#00 (measured by vendor) or ASTM \#0.5 (measured by GE), whereas for Heat XX63A8UK it was ASTM \#4.5 (measured by the same vendor only). Other differences include the product form [16 mm (5/8”) plate for Heat XX14A6UK, whereas $44.5 \mathrm{~mm}\left(13 / 4^{\prime \prime}\right)$ round bar for Heat XX63A8UK] and the solution annealing temperature $\left[1204^{\circ} \mathrm{C}\left(2200^{\circ} \mathrm{F}\right)\right.$ for Heat XX14A6UK, whereas $1177^{\circ} \mathrm{C}$ $\left(2150^{\circ} \mathrm{F}\right)$ for Heat XX63A8UK]. The "L" rating of Heat XX63A8UK may partly be attributed to its relatively finer grain size and some other factors despite its $\mathrm{Ti}$ concentration. The review also reveals that the third group heat, XX00A3US, was rated into the third group due to its data scatter. In Ni base alloys, titanium can usually form 
titanium carbonitrides, titanium carbides, and titanium nitrides. It can also replace $\mathrm{Al}$ in contributing to the formation of $\gamma$ '. The two " $L$ " heats observed in the high Ti range in Figure 14 may indicate that the Ti concentration should be balanced with that of some other elements to be effective in strengthening, or that some other factors can dominate and cancel the strengthening effects of $\mathrm{Ti}$, as discussed for Heat XX63A8UK.

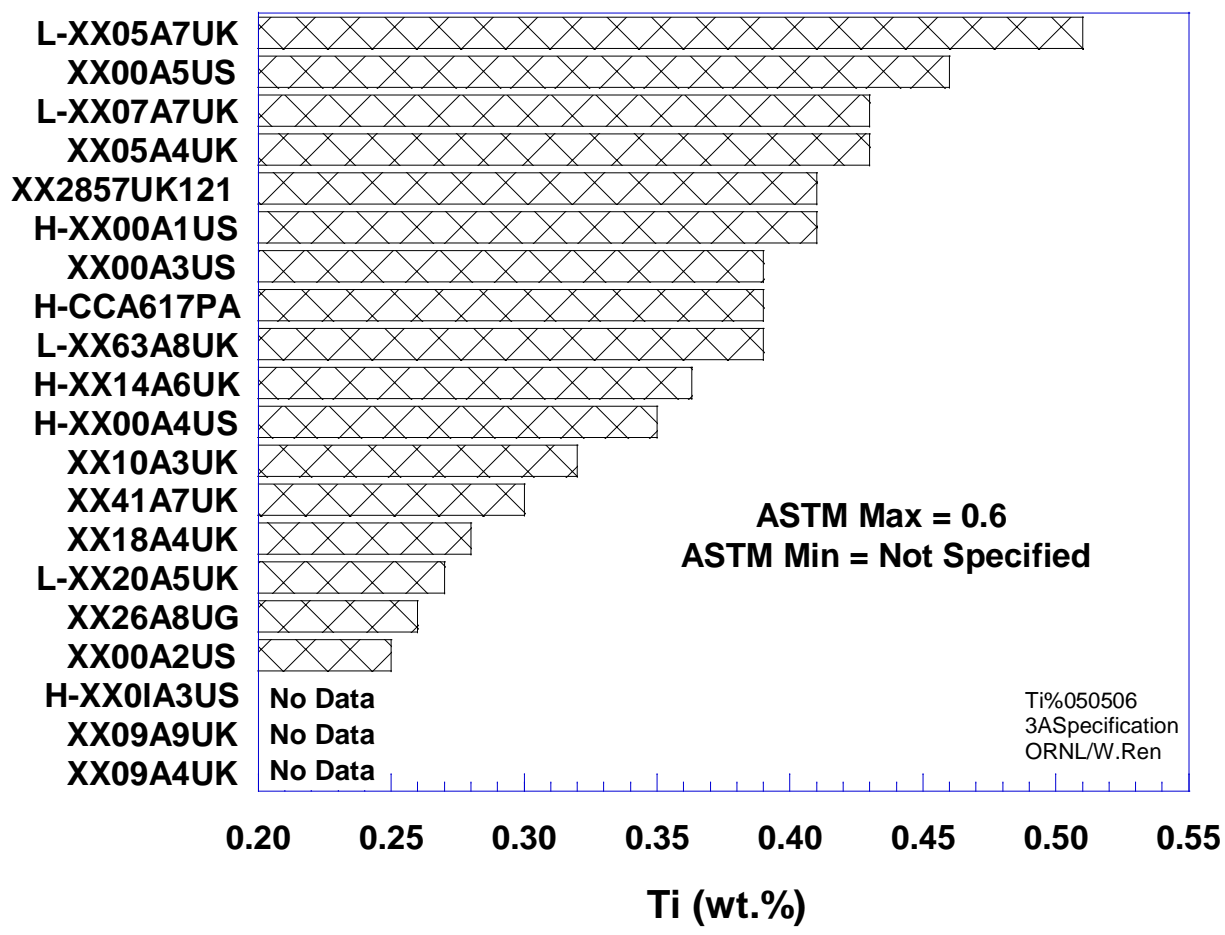

Figure 14. Ti concentration in various heats

It is worth mentioning that the concentration of $\mathrm{Ti}$ is not very easy to control in alloy manufacturing process because it easily forms titanium oxide, titanium carbide, and titanium carbonitride in the melt. It is especially difficult when $\mathrm{N}$ coexists in the melt because they are likely to form titanium nitride. Once formed, these particles can float in the melt and Ti can not go into the solid material as desired.

Figure 15 shows the content of $\mathrm{Al}$ in various heats. No direct correlation can be observed between the Al concentration and the creep strength. This may be attributed to the fact that within the ASTM chemistry specification, $\gamma^{\prime}\left(\mathrm{Ni}_{3} \mathrm{Al}\right)$ is not a stable phase at certain temperature range; when the heats were rated for " $\mathrm{H}$ " or " $\mathrm{L}$ ", they were not compared using the same number of data points systematically generated in the same temperature range; the comparison was done on whatever data available regardless of temperature and data numbers. Therefore some heats may have data in the temperature range where $\gamma^{\prime}$ contributes more to the strength while the others have data in the temperature range where $\gamma^{\prime}$ contributes less to the strength. The contribution of $\mathrm{Al}$ through $\gamma^{\prime}$ may thus be clouded. 
It is also noticed that Heat XX01A3US has an Al level of 0.76, lower than the ASTM standard specification minimum limit. This is very unusual for a commercial product from a prestigious vendor. It can not be completely ruled out that this data point is erroneous.

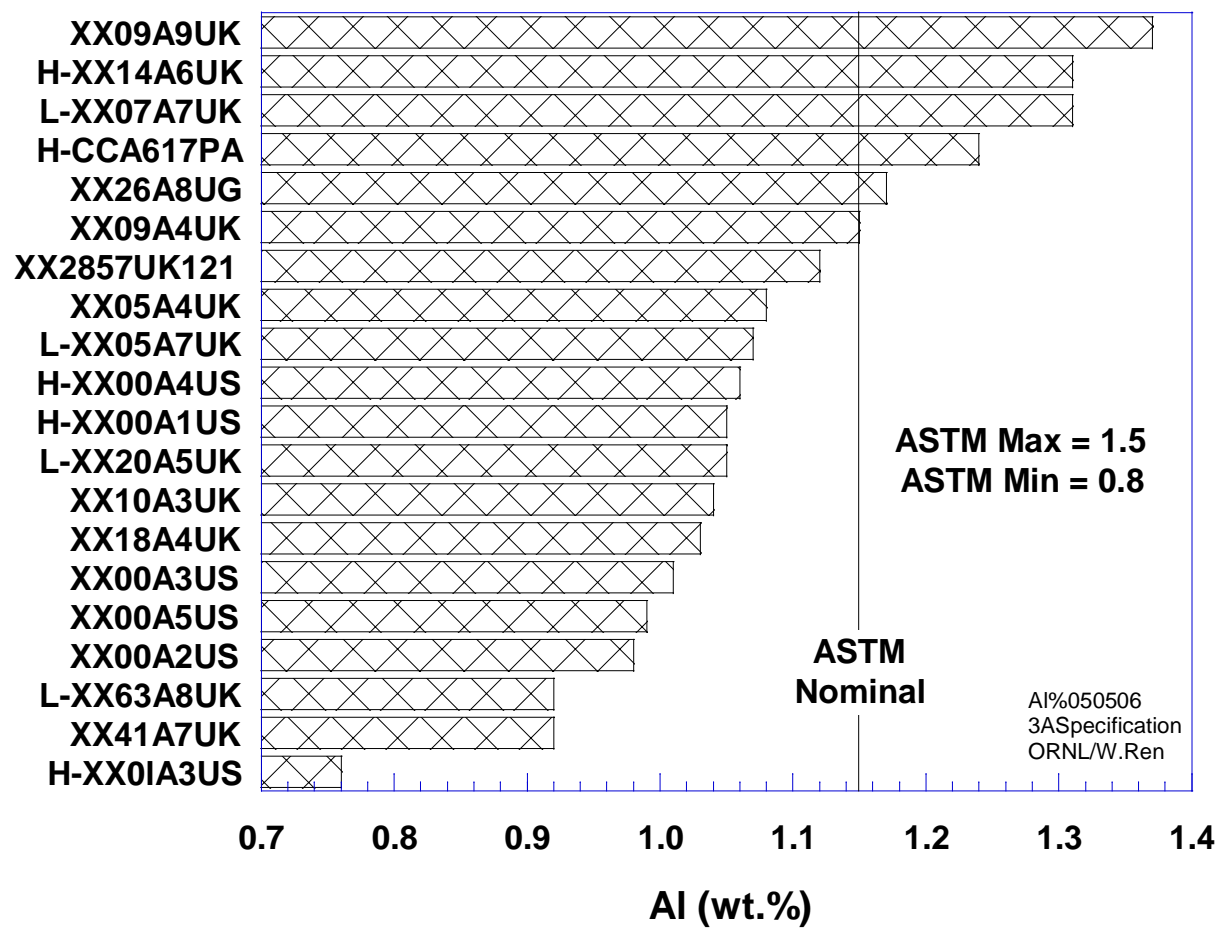

Figure 15. Al concentration in various heats

Nevertheless, literature review suggest that high Al level helps increase creep strength. The study on the three heats shown in Figure 1 reported that the strongest heat of the three was a thick-walled tube product with a high $\mathrm{Al}$ content of $1.35 \%$; whereas the weakest heat had an $\mathrm{Al}$ content of $0.82 \%$ and was produced as a hot-rolled bar [4]. Another study on heats with systematic chemistry variations also indicated that the high Al heats exhibited higher creep strength and lower minimum creep rate [7]. The drawbacks of high Al level include reduction of impact energy at ambient temperature [7]; and increase of the potential for hot cracking in welding. According to a recent study comparing Alloy 617 to Alloy 230, high Al in Alloy 617 also seems to worsen internal oxidation [8].

Figure 16 presents the concentrations of B. It can be observed that the " $\mathrm{H}$ " heats that have concentration data are all located in the relatively high range; Heat XX00A5US has almost reached the ASTM maximum limit with its B level of 0.0059. However, XX63A8UK, an " $\mathrm{L}$ " heat, is also located in the same high level range. As mentioned in Section 4.1, there are two measurements for the composition of Heat XX63A8UK, i. e., 0.003 measured by the vendor before ESR, and 0.005 measured by GE prior to the mechanical testing (i. e., after ESR). The higher GE value is used in Figure 16. It is discussed in Section 4.1 that the ESR process would usually decrease the concentration of 
some elements. However, comparison of the two B measurements indicates the opposite. This suggests that the B measurements of Heat XX63A8UK may not be accurate. Since the measurements were conducted about 20 to 30 years ago, the actually conditions are unknown for the present analysis. It is possible that the actual B level of the heat is lower than is shown. It should also be noted that in Figure 16 some heats are presented with an arrow pointing to the lower content direction. These are the heats with their compositions measured before the ESR. The arrow indicates that the actually $\mathrm{B}$ concentration would be lower than presented, as discussed in Section 4.1. With the errors and uncertainties excluded, the result from Figure 16 indicates it is very likely that the high B level contributed to the above-average creep strength of the " $\mathrm{H}$ " heats. Usually B acts as an electron donor; it can affect the grain boundary energy and help improve ductility. In Ni base alloys, B can also segregates to grain boundaries and contributes to slowing down grain boundary diffusion, thus reducing creep process.

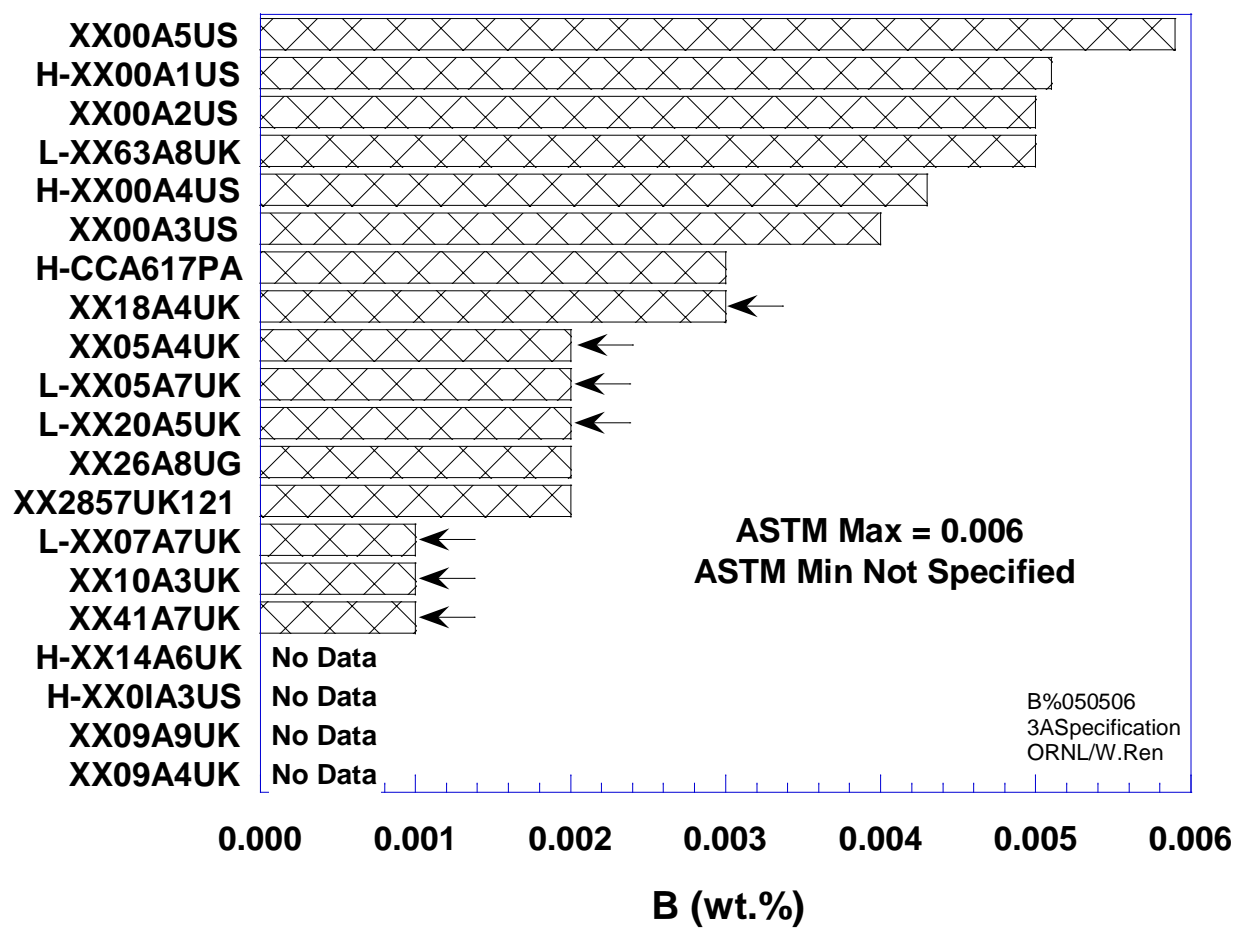

Figure 16. B concentration in various heats

The concentrations of Co and Mo in various heats are presented in Figures 17 and 18. Again, an arrow indicates the heat actually has lower concentration than presented due to the ESR practice. No trend can be observed to relate the concentrations of Co and Mo to the " $\mathrm{H}$ " and " $\mathrm{L}$ " rating. Both elements contribute to strength mainly through the solid solution strengthening mechanism, which is usually not the dominating strengthening mechanism at high temperatures. The " $\mathrm{H}$ " and " $\mathrm{L}$ " rating of these heats may have mostly resulted from precipitation strengthening rather than solid solution strengthening. 


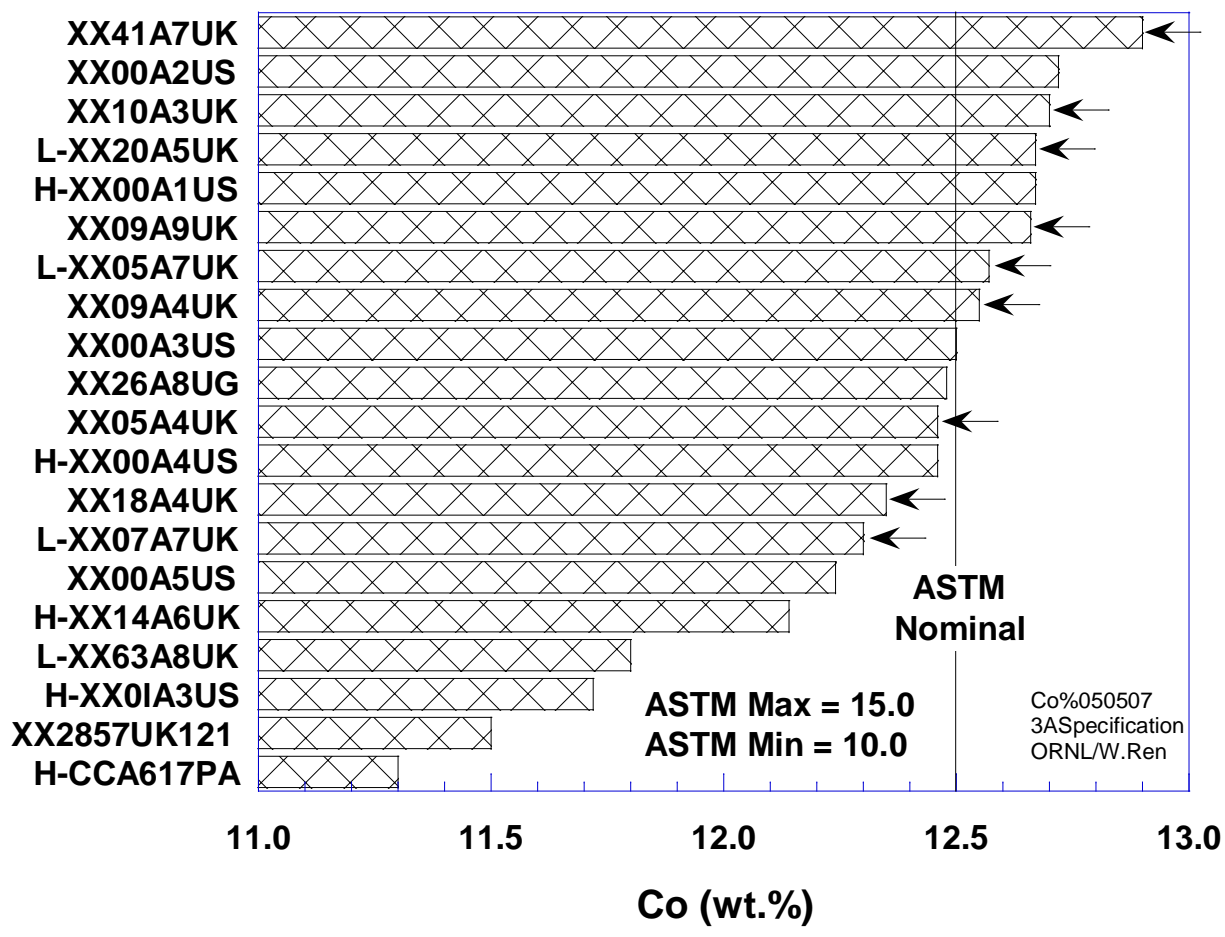

Figure 17. Co concentration in various heats

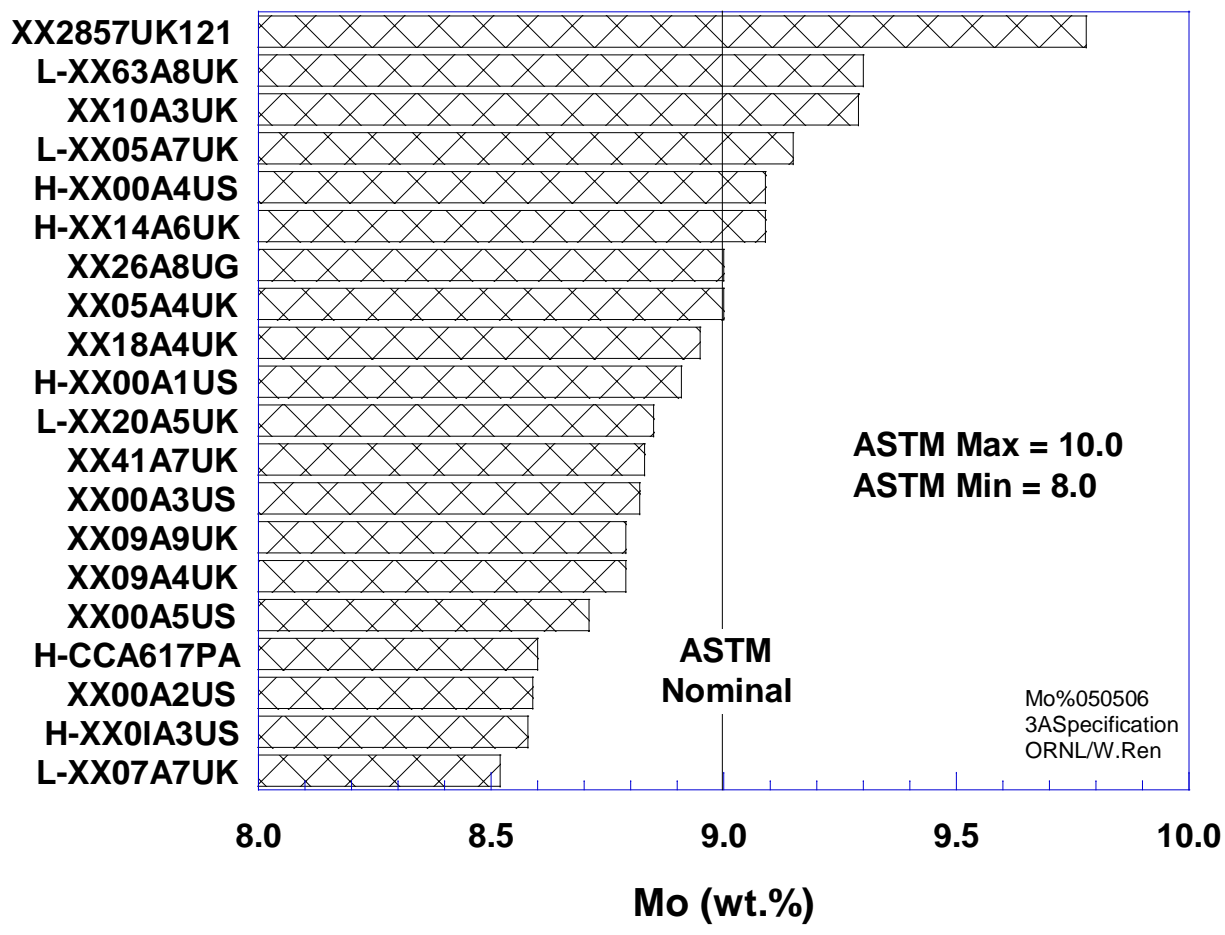

Figure 18. Mo concentration in various heats 
At high temperatures, diffusional creep processes control creep. Co is a large, high melting point, slow diffusion solute element and can help slow down diffusion and thus increase creep resistance in addition to providing substitutional solute strengthening. However radiation may become a concern as the Co level is increased. Mo is also a large, high melting point, slow diffusion solute element. Like Co, Mo can also help slow down diffusion and increase creep resistance, but it does not raise the radiation concern like the Co.

The concentration of $\mathrm{C}$ is presented in Figure 19. No obvious correlation can be found between the concentration and the rating. C contributes to the strength of Alloy 617 mainly by forming carbides with metallic strengthening elements. It has to be balanced with the metallic elements to be effective. High $\mathrm{C}$ concentration usually helps improve strength. However, too high in $\mathrm{C}$ may cause problems such as reduction in ductility and poor weldability.

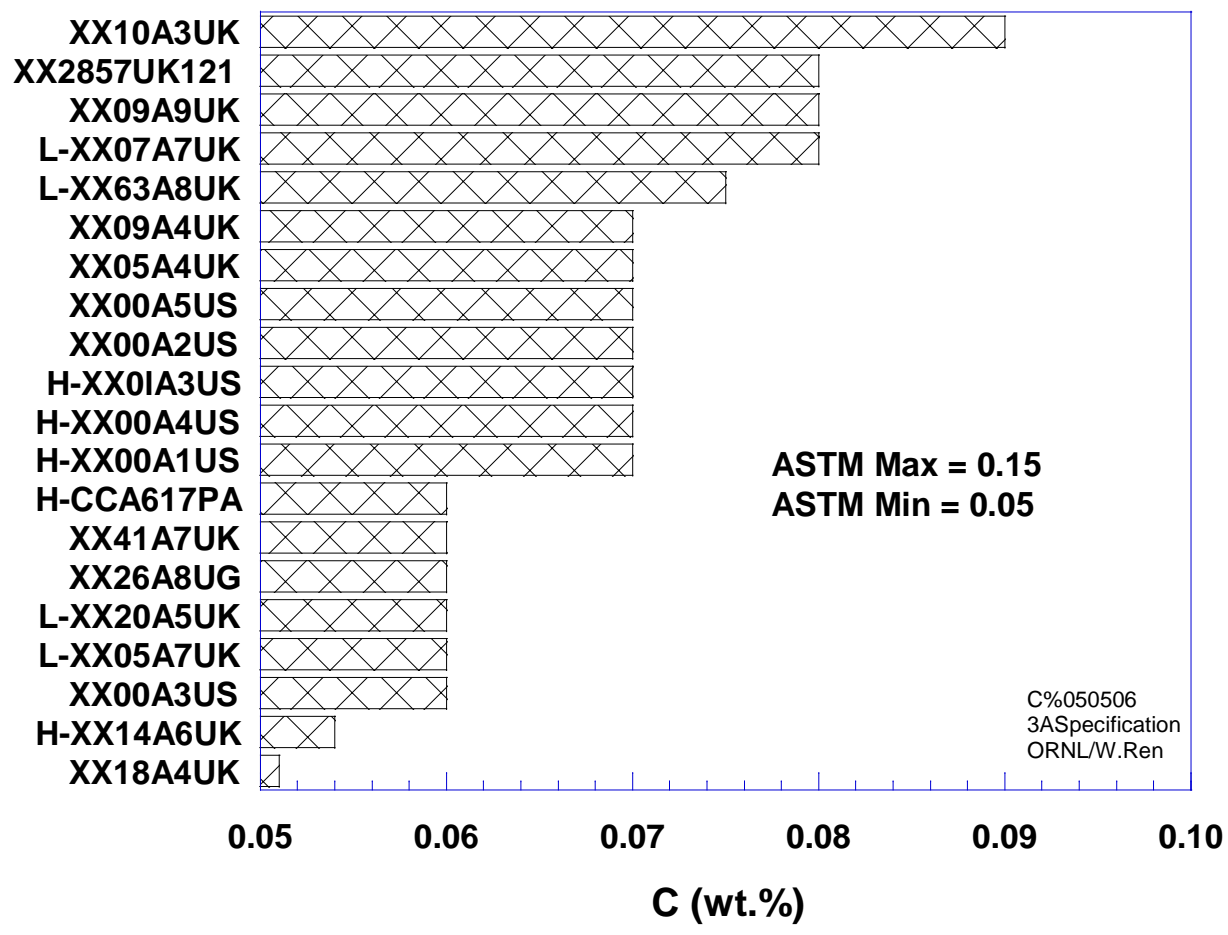

Figure 19. C concentration in various heats

The other elements are not the major contributors to high temperature strength of the alloy. Ni serves as the base element, providing matrix to the alloy. Cr, Mn, and Si can contribute to oxidation resistance, but high Si level can reduce ductility. Fe is added mainly for reducing the cost. $\mathrm{S}$ and $\mathrm{P}$ are residual elements harmful to ductility and should be restricted. Although $\mathrm{N}$ is not stipulated in the ASTM standard specifications for Alloy 617, some $\mathrm{N}$ is preferred because it contributes to strength as an interstitial solid solution element and a nitride former. However, too much $\mathrm{N}$ would affect the $\mathrm{Ti}$ 
concentration because of the easy formation of TiN particles in the melt as previously discussed.

The above element analysis clearly indicates that although these elements are largely responsible for the strength of the alloy, the correlation between the strength and the concentration of these elements can be very complicated. In addition to other factors such as grain size, heat treatment, product form etc. that could have clouded the correlation, these elements contribute to strength in "collaboration". In other words, it is the appropriate combination of these elements that are important to the strength of the alloy rather than the elements separately considered. To efficiently identify the appropriate combination, a well-planned, purpose-oriented, systematically generated database is required. Unfortunately, the available data employed for the above analysis are generated for other purposes by various sources, and the information needed is often found incomplete, let alone being systematic.

\subsection{Previous Specification Development Effort at ORNL}

In the mid 1980's, an effort similar to the present investigation was briefly made at ORNL to enhance high temperature properties of Alloy 617 in the research for materials for the HTGR project [7]. Several variant heats of Alloy 617 were systematically designed and produced for study. The research did not completely confine the element concentrations to the ASTM standard chemistry specification limits. The compositions of these heats are listed in Table 6 of Section 4.1. As shown in the table, in Heats 800 through 805, the concentrations of $\mathrm{Al}$, Ti and $\mathrm{Cr}$ were varied systematically with all $\mathrm{Al}$ remaining in the ASTM standard specification limits, but some $\mathrm{Cr}$ and all Ti straying out of the limits; in Heats 492, 493, and 494, the Cr concentration was varied from within to out of the ASTM standard specification while the Ti concentrations were all out of the specification.

Creep test results from Heats 800 through 805 at 760 and $871^{\circ} \mathrm{C}\left(1400\right.$ and $\left.1600^{\circ} \mathrm{F}\right)$ indicate that Heats 800 (2Ti, 0.1Al, 22Cr) and $801(2 \mathrm{Ti}, 0.5 \mathrm{Al}, 22 \mathrm{Cr}$ ) were stronger; whereas Heats 802 (1Ti, 0.1Al, 22Cr), 804 (1Ti, 0.5Al, 16Cr) and 805 (1Ti, 0.5Al, 12Cr) were weaker and had about equivalent strengths. Heat 803 (1Ti, 0.5Al, 22Cr) fell intermediate, with good strength at a low stress level and poor strength at a higher stress level. Optical microstructure analysis of the creep specimens tested at $760^{\circ} \mathrm{C}\left(1400^{\circ} \mathrm{F}\right)$ show that Heat 801 (the strongest) had a significant amount of precipitates which were likely carbides and $\gamma^{\prime}$, while Heat 803 (the intermediate) had predominantly carbides with little, if any, $\gamma$ '; and Heats 804 and 805 (the weaker heats) contained fine precipitates, likely carbides. It is unfortunate that no advanced microstructural characterization technologies were used to analyze the details of these precipitates and the microstructure of Heat 802 was not reported.

Results from Heats 492, 493 and 494 at 760 and $871^{\circ} \mathrm{C}\left(1400\right.$ and $\left.1600^{\circ} \mathrm{F}\right)$ indicate that creep strength remained at the same range with very slight decrease as $\mathrm{Cr}$ concentration was reduced from 22.7, 16.2 to $12.4 \%$. However, the extent of aging was 
reduced by reducing the Cr content, which is observed in the lowest impact energy of the $22.7 \%$ heat among the three after aging at $704^{\circ} \mathrm{C}\left(1300^{\circ} \mathrm{F}\right)$ for 10,000 hours.

By comparing all these heats to the standard 617, a reduction in the extent of carburization after testing in the HTGR helium was revealed, and the reduction was attributed to the high Ti levels in all these heats.

Although this investigation was systematically design, the results should not be considered conclusive because not enough creep tests were conducted for each condition. However, the effects of $\mathrm{Al}, \mathrm{Ti}$ and $\mathrm{Cr}$ concentrations in properties of the alloy have been preliminarily exhibited, and the trend can be used as a guide in refining the chemistry specification of the alloy.

It should be pointed out that in spite of the relative creep strengths among these heats as described above, the overall creep strength of the heats did not demonstrate significant improvement compared to the baseline average behavior, especially at $871^{\circ} \mathrm{C}\left(1600^{\circ} \mathrm{F}\right)$, as shown in Figures 20 and 21. It is also worth mentioning that no discernable difference in creep rupture stress of these heats between air and the HTGR helium testing environments is exhibited.

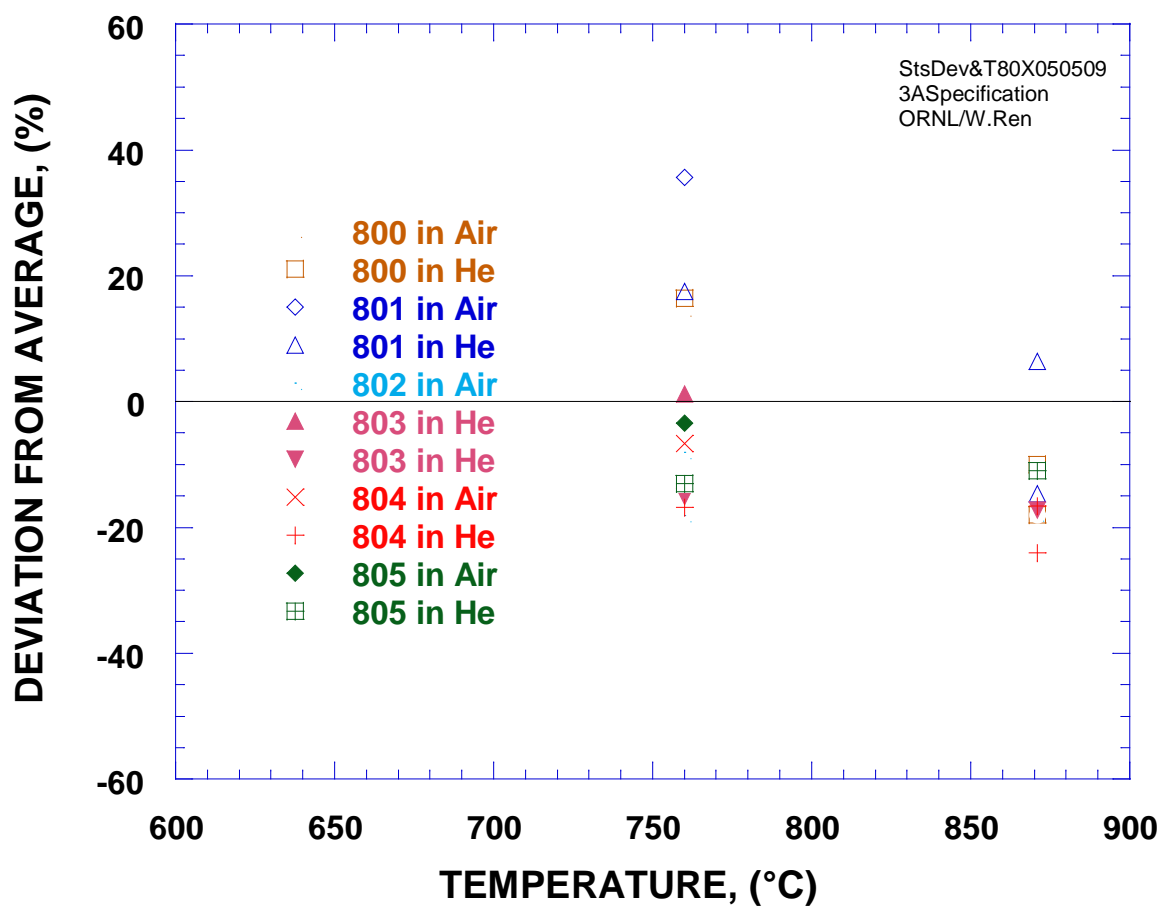

Figure 20. Creep rupture stress deviation of Heats 800 to 805 from the average creep strength at various temperatures 


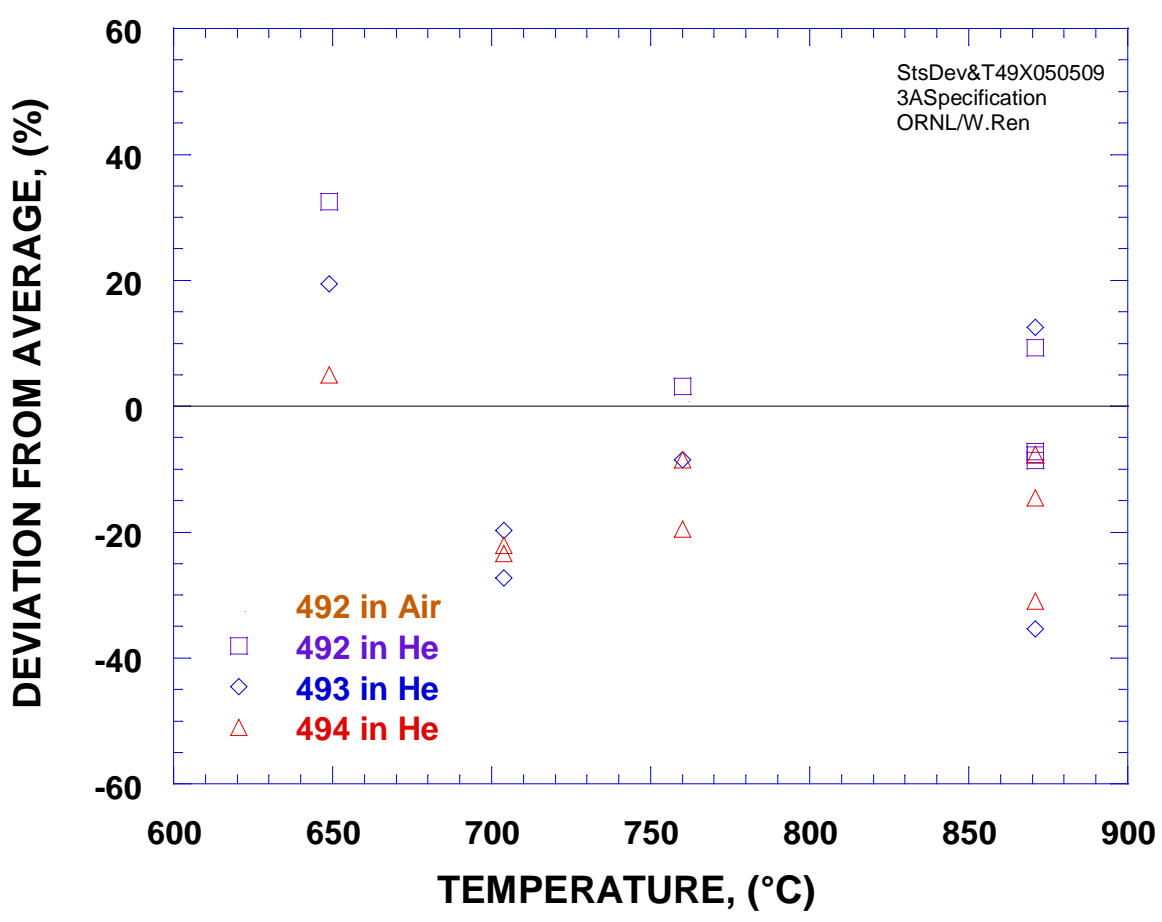

Figure 21. Creep rupture stress deviation of Heats 492 to 494 from the average creep strength at various temperatures

\subsection{Strengthening Element and Mechanism Analysis}

Alloys for high temperature applications are mainly strengthened by three mechanisms: solid solution, precipitation, and dispersion. Grain boundaries also have a significant effect on high temperature strength. Alloy 617 is strengthened by both solid solution and precipitation mechanisms. As previously described, the solid strengthening is mainly imparted by Co and Mo. Reported precipitates in Alloy 617 include several second phases such as carbides $\mathrm{M}_{23} \mathrm{C}_{6}$ and $\mathrm{M}_{6} \mathrm{C}$, intermetallic compounds $\gamma^{\prime}$ and $\mu$, carbonitride $\mathrm{Ti}(\mathrm{C}, \mathrm{N})$, and others, each being found in certain temperature range. Existing in appropriate sizes, distributions, and volume fractions, these second phases can enhance high temperature strength of the alloy. In developing the refined chemistry specification, efforts must be made to understand and explore the strengthening capacity of these precipitates.

However, observations and predictions of these precipitates in Alloy 617 have not been consistent from different researchers.

Preliminary thermodynamic prediction of the second phases in Alloy 617 has been conducted at ORNL using Thermo-Calc ${ }^{\mathrm{TM}}$ computational analysis based on the ASTM standard specification chemistry [9]. The calculation indicated that two carbides and two 
intermetallics would form in Alloy 617. The $\mathrm{M}_{23} \mathrm{C}_{6}$ carbide was expected to be stable below $800^{\circ} \mathrm{C}\left(1472^{\circ} \mathrm{F}\right)$ and the $\mathrm{M}_{6} \mathrm{C}$ carbide was expected to form above $780^{\circ} \mathrm{C}\left(1436^{\circ} \mathrm{F}\right)$. Less than 5 weight percent $\gamma^{\prime}$ was expected to persist to $650^{\circ} \mathrm{C}\left(1202^{\circ} \mathrm{F}\right)$, and more than 10 weight percent $\mu$ phase was expected at $600^{\circ} \mathrm{C}\left(1112^{\circ} \mathrm{F}\right)$ but would vanish by $800^{\circ} \mathrm{C}$ $\left(1472^{\circ} \mathrm{F}\right)$. Mankins, et al. [10] found the $\mathrm{M}_{23} \mathrm{C}_{6}$ carbide to persist to $1093^{\circ} \mathrm{C}\left(2000^{\circ} \mathrm{F}\right)$ and a small amount of $\gamma^{\prime}$ to persist to $760^{\circ} \mathrm{C}\left(1400^{\circ} \mathrm{F}\right)$. The findings of Kimball, et al. [11] were consistent with Mankins et al. [10]. Kihara, et al. [12] observed both $\mathrm{M}_{23} \mathrm{C}_{6}$ and $\mathrm{M}_{6} \mathrm{C}$ at $1000^{\circ} \mathrm{C}\left(1832^{\circ}\right)$, and attributed the strengthening in the alloy to the $\mathrm{M}_{23} \mathrm{C}_{6}$. An extensive examination of two heats of alloy 617 was undertaken by Kirchhofer, et al. [13]. In addition to the two carbides, they found a $\mathrm{Ti}(\mathrm{C}, \mathrm{N})$ precipitate to exist over the temperature range of 400 to $1000^{\circ} \mathrm{C}\left(752\right.$ to $\left.1832^{\circ} \mathrm{F}\right)$. The $\gamma^{\prime}$ was observed from 550 to $1000^{\circ} \mathrm{C}\left(1022\right.$ to $\left.1832^{\circ} \mathrm{F}\right)$. Most of the aging studies were confined to material exposed for 10,000 hours and less. $\mathrm{Wu}$ and Vasudevan [14], however, recently examined specimens aged for much longer times over the temperature range of 482 to $871^{\circ} \mathrm{C}(900$ to $1600^{\circ} \mathrm{F}$ ). They found that $\mathrm{Cr}_{23} \mathrm{C}_{6}$ and eta-MC carbides were present for all aged conditions. TiN precipitates (or inclusions) were also observed. The $\gamma^{\prime}$ intermetallic phase was observed in specimens aged at 482,538 , and $593^{\circ} \mathrm{C}\left(900,1000\right.$, and $\left.1100^{\circ} \mathrm{F}\right)$ but not in those aged 43,000 hours and longer at $704^{\circ} \mathrm{C}\left(1300^{\circ} \mathrm{F}\right)$. Further, no $\gamma^{\prime}$ was observed after long time aging at $871^{\circ} \mathrm{C}\left(1600^{\circ} \mathrm{F}\right)$. This observation confirms the Thermo-Calc ${ }^{\mathrm{TM}}$ prediction as far as $\gamma^{\prime}$ is concerned, and suggests that the $\gamma^{\prime}$ formed early in exposures at $700^{\circ} \mathrm{C}\left(1292^{\circ} \mathrm{F}\right)$ and above must go back into solution. The loss of creep strength at the temperatures of interest for the VHTRs may be influenced by this process. In addition to these major second phases, some other phases such as the $\operatorname{CrMo}(\mathrm{C}, \mathrm{N})$ [10], the ultra-fine, long-range ordered Ni2(Mo, Cr) (P2Mo structure) [14] have also been reported. The major second phases observed by different sources are summarized in Table 7.

To provide a complete vision of the second phase precipitation in an alloy, a timetemperature-transformation (TTT) diagram is used. The TTT diagram of Alloy 617 constructed by the Germans is presented in Figure 22 [15]. The diagram shows the second phase precipitates that would exist in Alloy 617 during various time periods at different temperatures. Verification research has been conducted at ORNL under the Fossil Energy Advanced Research Materials Program through mechanical testing and microstructural analysis of long-term aged Alloy 617. Preliminary results indicate that a number of alterations to the diagram are necessary below $1000^{\circ} \mathrm{C}$ [16]. It is suggested that the $\mathrm{M}_{6} \mathrm{C}$ end curve at 600 to $800^{\circ} \mathrm{C}\left(1112\right.$ to $\left.1472^{\circ} \mathrm{F}\right)$ for 1,000 to 10,000 hours should be removed because the $\mathrm{M}_{6} \mathrm{C}$ carbide has been identified in that temperature range in all the specimens investigated. The $\mathrm{Ni}_{2}(\mathrm{Mo}, \mathrm{Cr})$ phase has also been observed at $482^{\circ} \mathrm{C}\left(900^{\circ} \mathrm{F}\right)$ and should be added to the diagram. However, because it has only been observed at this temperature without demonstrating significant hardening effects and the phase has not been included in the Thermo-Calc ${ }^{\mathrm{TM}}$ database, there is not sufficient data to construct a C-curve for it. Another necessary alteration is the extension of the $\gamma^{\prime}$ curve to temperatures below $550^{\circ} \mathrm{C}\left(1022^{\circ} \mathrm{F}\right)$ based on the identification of $\gamma^{\prime}$ in specimens aged at 482 and $538^{\circ} \mathrm{C}\left(900\right.$ and $\left.1000^{\circ} \mathrm{F}\right)$ as well as the Thermo-Calc ${ }^{\mathrm{TM}}$ predictions. The final addition to the diagram is the inclusion of an end to the $\gamma^{\prime}$ phase precipitates. Specimens aged for long times at 704 and $871^{\circ} \mathrm{C}\left(1300\right.$ and $\left.1600^{\circ} \mathrm{F}\right)$ did not exhibit $\gamma^{\prime}$, but the $\gamma^{\prime}$ 
DEVELOPMENT OF A CONTROLLED MATERIAL SPECIFICATION FOR ALLOY 617 FOR NUCLEAR APPLICATIONS

phase has been identified in specimens aged for shorter times at $704^{\circ} \mathrm{C}\left(1300^{\circ} \mathrm{F}\right)$ [10]. Hardness maximums measured at 704,760 , and $816^{\circ} \mathrm{C}\left(1300,1400\right.$, and $\left.1600^{\circ} \mathrm{F}\right)$ over a range of times indicate coarsening or potential dissolution of $\gamma^{\prime}$ precipitates.

Table 7. Prediction and Observations of Second Phase Precipitates in Alloy 617

\begin{tabular}{|c|c|c|c|c|c|}
\hline Investigator & $\mathrm{M}_{23} \mathrm{C}_{6}$ & $\mathrm{M}_{6} \mathrm{C}$ & $\gamma^{\prime}$ & $\mu$ & $\operatorname{Ti}(\mathbf{C}, \mathbf{N})$ \\
\hline $\begin{array}{l}\text { Thermocalc® } \\
\text { Prediction [9] }\end{array}$ & $\begin{array}{c}\text { Predicted } \\
\mathrm{T} \leq 800^{\circ} \mathrm{C}\end{array}$ & $\begin{array}{l}\text { Predicted } \\
\mathrm{T} \geq 780^{\circ} \mathrm{C}\end{array}$ & $\begin{array}{l}\mathrm{wt}<5 \% \\
\text { predicted } \\
\mathrm{T} \leq 650^{\circ} \mathrm{C}\end{array}$ & $\begin{array}{c}\text { wt }>10 \% \\
\text { predicted } \\
600 \sim \\
800^{\circ} \mathrm{C}\end{array}$ & Not reported \\
\hline \multicolumn{6}{|c|}{ Observation in material aged for 10,000 hours and less } \\
\hline $\begin{array}{l}\text { Mankins [10] } \\
\text { Kimball [11] }\end{array}$ & $\begin{array}{c}\text { Observed } \\
\mathrm{T} \leq 1093^{\circ} \mathrm{C}\end{array}$ & Not reported & $\begin{array}{c}\text { Small } \\
\text { amount } \\
\text { observed } \\
\mathrm{T} \leq 760^{\circ} \mathrm{C}\end{array}$ & $\begin{array}{c}\text { Not } \\
\text { observed }\end{array}$ & $\begin{array}{c}\text { Not } \\
\text { observed }\end{array}$ \\
\hline Kihara [12] & $1000^{\circ} \mathrm{C}$ & $1000^{\circ} \mathrm{C}$ & Not reported & $\begin{array}{c}\text { Not } \\
\text { observed }\end{array}$ & Not reported \\
\hline $\begin{array}{c}\text { Kirchhofer } \\
\text { [13] }\end{array}$ & Observed & Observed & $\begin{array}{c}550 \sim \\
1000^{\circ} \mathrm{C} .\end{array}$ & $\begin{array}{c}\text { Not } \\
\text { observed }\end{array}$ & $\begin{array}{c}400 \sim \\
1000^{\circ} \mathrm{C}\end{array}$ \\
\hline \multicolumn{6}{|c|}{ Observation in material aged for much longer than 10,000 hours at $482 \sim 871^{\circ} \mathrm{C}$} \\
\hline Wu [14] & Observed & $\begin{array}{l}\text { Observed } \\
\text { Also } \\
\text { observed } \\
\text { eta-MC }\end{array}$ & $\begin{array}{c}\text { Observed at } \\
482,538, \& \\
593^{\circ} \mathrm{C}, \\
\text { not at } 704^{\circ} \mathrm{C} \\
\text { after } 43,000 \\
\text { h and longer, } \\
\text { nor } 870^{\circ} \mathrm{C} \\
\text { after long } \\
\text { time. }\end{array}$ & $\begin{array}{c}\text { Not } \\
\text { observed }\end{array}$ & $\begin{array}{c}\text { TiN } \\
\text { Observed }\end{array}$ \\
\hline
\end{tabular}

As indicated in Figure 7, the above-average creep strength deviation of the CCA 617 peaks at $700^{\circ} \mathrm{C}\left(1292^{\circ} \mathrm{F}\right)$ and drops back to the average at $800^{\circ} \mathrm{C}\left(1472^{\circ} \mathrm{F}\right)$. This behavior is consistent with the trend in volume fraction change of $\gamma^{\prime}$ with time and temperature observed through microstructural analysis on CCA 617 in a study led by ORNL. It was observed that at 700 and $750^{\circ} \mathrm{C}\left(1292\right.$ and $\left.1382^{\circ} \mathrm{F}\right)$, there was a gradual increase in the volume fraction of $\gamma^{\prime}$ with the aging time, while at $800^{\circ} \mathrm{C}\left(1472^{\circ} \mathrm{F}\right)$ the volume fraction of $\gamma^{\prime}$ increased and then decreased dramatically by 3,000 hours [16]. The volume fraction variation as a function of aging time at 700,750 , and $800^{\circ} \mathrm{C}\left(1292,1832\right.$ and $\left.1472^{\circ} \mathrm{F}\right)$ estimated based on microanalysis is given in Figure 23, and transmission electron microscope (TEM) observations of the $\gamma^{\prime}$ are presented in Figure 24. If the deviation of CCA 617 indicated in Figure 7 is indeed caused by the $\gamma$ ' precipitates due to its controlled chemistry, sustaining the $\gamma^{\prime}$ up to the temperatures of interest to the VHTRs would be one of the approaches for improving high temperature properties. However, long-time 
strengthening by $\gamma^{\prime}$ at temperatures above $750^{\circ} \mathrm{C}\left(1832^{\circ} \mathrm{F}\right)$ seems unlikely since there are no data up to date that indicate that the phase will be stable at the high temperature. If present, coarsening of the precipitate would be expected, and softening would occur as suggested by hardness versus aging time data [16].

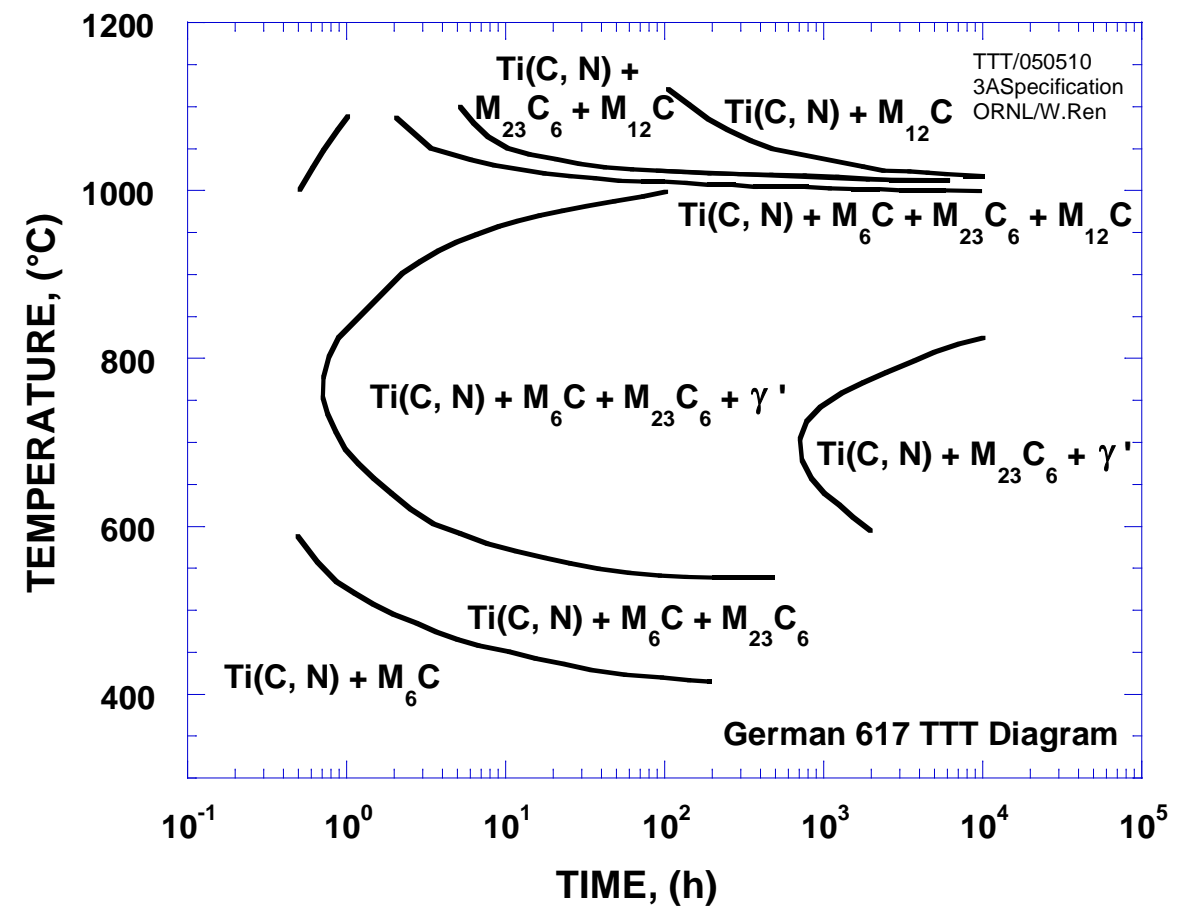

Figure 22. German Time-Temperature-Transformation Diagram of Alloy 617

Volume fraction of gamma prime in aged CCA 617

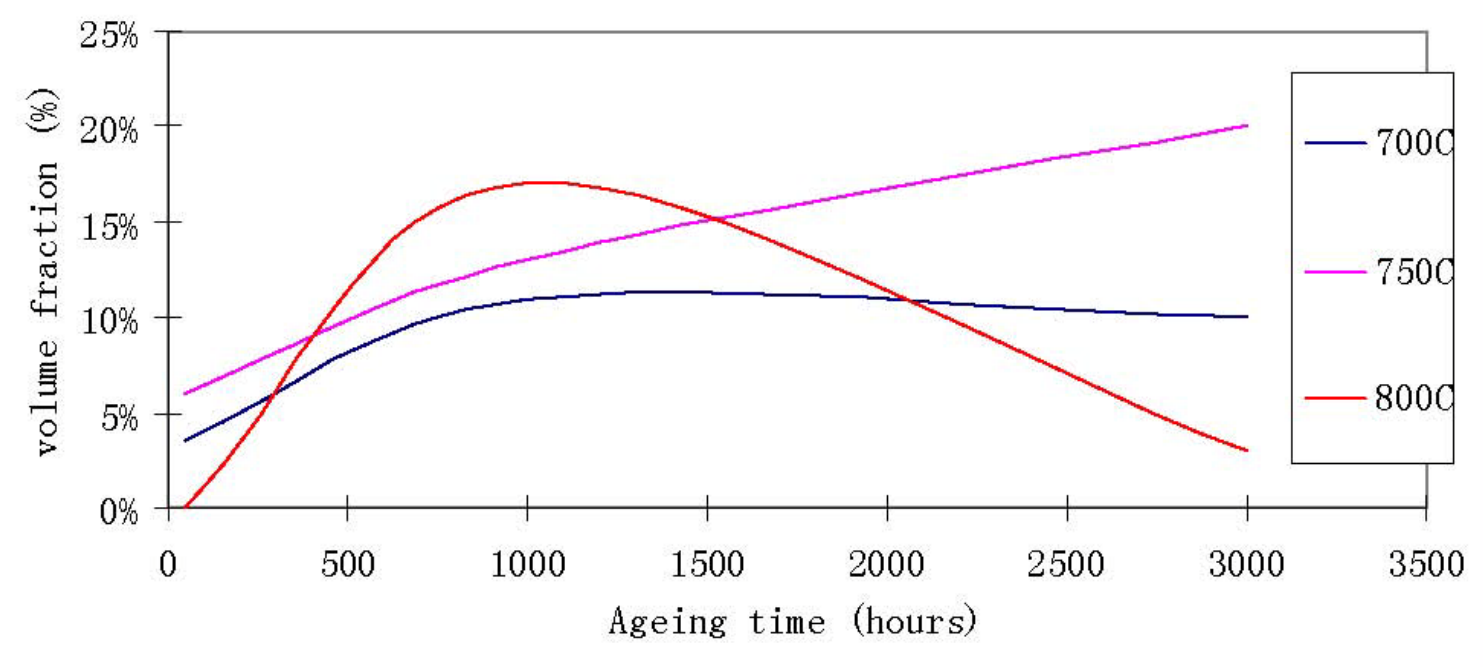

Figure 23. Estimated $\gamma^{\prime}$ volume fraction variation with time at various temperatures in aged CCA 617 [16] 


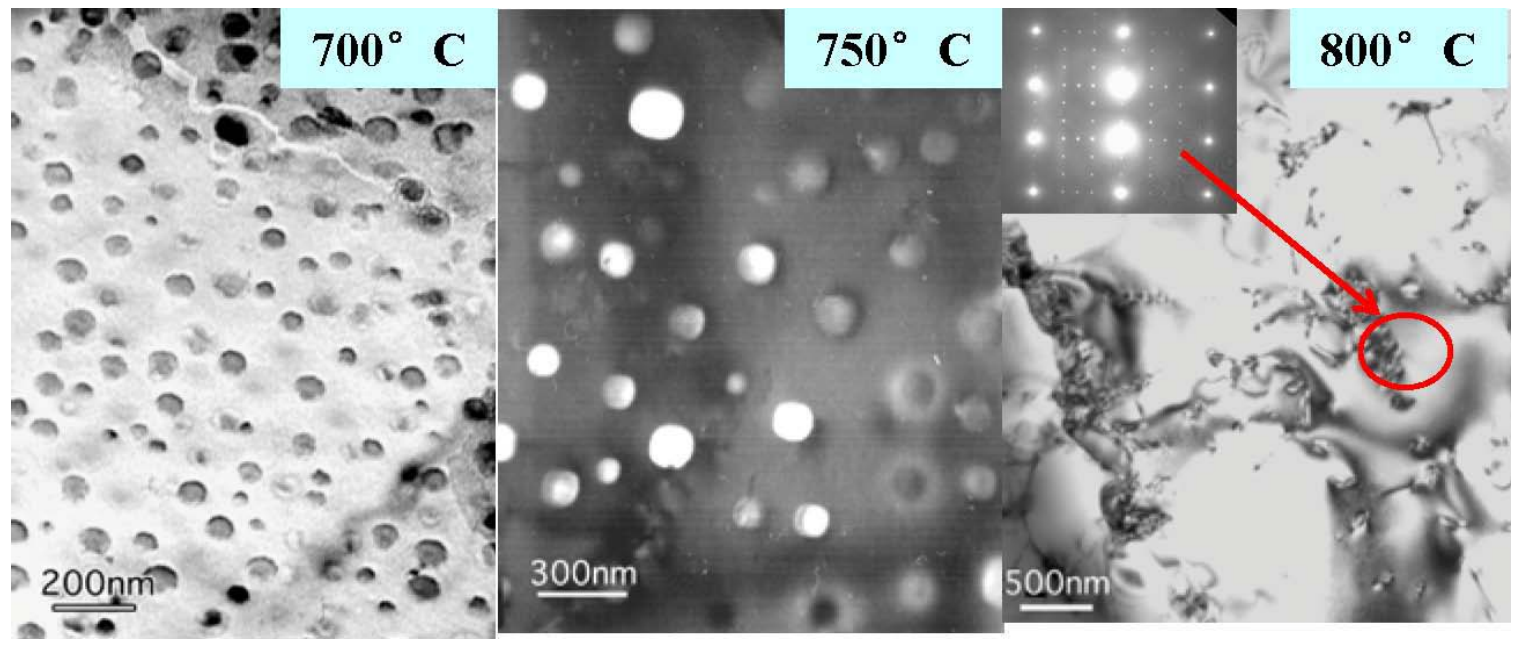

Figure 24. TEM images of gamma prime $\left(\gamma^{\prime}\right)$ precipitates in CCA 617 after aging at 700, 750 , and $800^{\circ} \mathrm{C}\left(1292,1832\right.$ and $\left.1472^{\circ} \mathrm{F}\right)$ for 3,000 hours [16]

Table 8. Roll of Alloying Elements in Superalloys [17]

\begin{tabular}{|c|c|c|c|c|c|}
\hline Element & $\begin{array}{c}\text { Gamma } \\
\text { Hardening }\end{array}$ & $\begin{array}{c}\mathrm{M}_{23} \mathrm{C}_{6} \\
\text { at } 815^{\circ} \mathrm{C}\end{array}$ & $\begin{array}{c}\mathrm{M}_{23} \mathrm{C}_{6} \\
\text { at } 980^{\circ} \mathrm{C}\end{array}$ & $\begin{array}{c}\mathrm{M}_{6} \mathrm{C} \\
\text { at } 980^{\circ} \mathrm{C}\end{array}$ & $\begin{array}{c}\text { Grain Boundary } \\
\text { Stability }\end{array}$ \\
\hline $\mathrm{Co}$ & $+\mathrm{W}$ & $\ldots$ & $\ldots$ & $\ldots$ & + \\
\hline $\mathrm{Fe}$ & $+\mathrm{M}$ & $-\mathrm{W}$ & $\ldots$ & $\ldots$ & $\ldots$ \\
\hline $\mathrm{Cr}$ & $+\mathrm{S}$ & $+\mathrm{M}$ & $+\mathrm{S}$ & $-\mathrm{W}$ & $\ldots$ \\
\hline $\mathrm{Mo}$ & $+\mathrm{S}$ & $-\mathrm{S}$ & $-\mathrm{S}$ & $+\mathrm{S}$ & + \\
\hline $\mathrm{Ti}$ & $\ldots$ & $\ldots$ & $+\mathrm{S}$ & $-\mathrm{S}$ & $\ldots$ \\
\hline $\mathrm{Al}$ & $+\mathrm{S}$ & $\ldots$ & $+\mathrm{S}$ & $-\mathrm{S}$ & $\ldots$ \\
\hline $\mathrm{B}$ & $\ldots$ & & $\ldots$ & $\ldots$ & + \\
\hline $\mathrm{C}$ & $\ldots$ & + & $\ldots$ & $\ldots$ & - \\
\hline $\mathrm{Mg}$ & $\ldots$ & $\ldots$ & $\ldots$ & $\ldots$ & + \\
\hline
\end{tabular}

Note: $\mathrm{W}=$ weak effect; $\mathrm{M}=$ moderate effect; $\mathrm{S}=$ strong effect;

+ = increase; - = decrease;.. . = no effect

Accepting the views of most researchers, it appears that control of the solute hardening elements and carbide-forming elements in Alloy 617 would be the best approach for optimizing properties for service above $750^{\circ} \mathrm{C}\left(1832^{\circ} \mathrm{F}\right)$. Some guidance is provided by Decker [17] who lists, qualitatively, the effects of elemental additions on $\gamma$, $\gamma^{\prime}$, carbides, and grain boundaries in nickel-base superalloys. Some of this information is summarized in Table 8. Information for $\gamma^{\prime}$ is not included. It is not clear whether Table 8 applies to nominally solid-solution strengthened alloys, since the emphasis of Decker 
was on $\gamma^{\prime}$ strengthened alloys. However, the elements in alloy 617 that have a strengthening effect on $\gamma$ are identified. Also elements that prove beneficial to the carbide phases are identified. Grain boundary stability is promoted by Co, Mo, B, and Mg. In recent years, efforts have been made to predict strength on the basis of an understanding of chemistry effects on phase stability and microstructural factors that promote strengthening [18] [19]. Again, emphasis is on the $\gamma^{\prime}$ strengthened alloys. However, all this information helps further research and understanding of the precipitates in Alloy 617, and provides some guidance for refining the specification. Currently discussion is underway to further investigate the precipitates in Alloy 617 for the Gen IV program in collaboration with the Fossil Energy Advanced Research Materials Program at ORNL.

\section{SPECIFICATION RECOMMENDATION}

\subsection{A Tentative Refined Specification}

Based on the analyses of mechanical properties and chemical compositions of historical data from various heats and the strengthening elements and mechanisms, a tentative refined specification of Alloy 617 is recommended for VHTR materials testing in this section. For the reasons discussed in Section 3.2, only the factors that need to be restricted are stipulated in this section, the others will remain unchanged for the time being as are in the ASTM standard specifications. As a reference, the unchanged items can be found in the ASTM standard specification of Alloy 617 for plate, sheet and strip in the Appendix.

\section{Chemistry}

The tentative refined chemistry is given in Table 9. It should be pointed out that the composition in Table 9 is recommended as a "best possible shot" effort under the current conditions regarding the historical data status and applicable information availability. Improvements should be expected as more and better information becomes available.

Recent documented personal communications with the Special Metals indicate that their present practice ensures chemistry analysis to be performed after the ESR, an important improvement compared to the old practice that produced the highlighted chemistry uncertainties shown in Table 5.

\section{Grain Size}

Large grain sizes are usually preferred for good creep resistance. However, it has to be balanced with good crack initiation resistance and other factors. One important consideration is the potential application in the Intermediate Heat Exchanger (IHX). Too large a grain size may cause some problems in the thin sheets required for the IHX. A grain size range of ASTM \#3-5 is recommended. Personal communications with the Special Metals indicate that they have gained much better control on the grain size than many years ago when the heats used for the Code stresses were produced. Currently they 
can produce the alloy in a typical grain size range of ASTM \#3-6. It is likely that the recommended grain size range can be achieved.

Heat Treatment

Solution annealing at ASME specified minimum temperature of $1149^{\circ} \mathrm{C}\left(2100^{\circ} \mathrm{F}\right)$ for a time commensurate with section size, followed by water quench cooling.

Melting Method

VIM + ESR for accurate control of the specified chemistry.

Composition Analysis and Report

A check analysis after ESR on all the specified elements should be performed and reported. Heat analysis should be provided as a reference.

\section{Product Form}

Hot rolled 3/4" thick plate for convenient specimen machining.

\subsection{Future Work}

The recommended specification is based on the analyses of historical data, literature review, experience, and knowledge about the alloy. As can be seen in the analyses, great difficulty lies in the fact that the historical data were not systematically generated for the purpose of refining the specification to improve properties. The analyses have also suffered from incomplete information, inconsistent, and even erroneous data mostly generated some 20 to 30 years ago during the HTGR time. Many advanced materials manufacturing and processing technologies were not available and many important factors that significantly affected the properties were not well controlled when these data were generated; whereas heats produced in recent years that are much better controlled lack the abundance of existing data. Furthermore, the current investigation has only been given approximately half a year to deliver this report; compared to the five years it took for the Modified 9Cr-1Mo steel to be developed from the standard 9Cr-1Mo steel, the deficiency of time is apparent. Therefore, the recommended specification should be considered tentative and subjected to further refining when more information becomes available.

To verify and further refine the recommended specification, the following actions should be considered:

1. As mentioned in Section 1, much work on Alloy 617 has been undertaken in Germany after the termination of US interest in nuclear application of the alloy in the late 1980's. Efforts have been underway to acquire recently generated data from the international community, especially from the Germans. Such efforts must be continued as more and more countries officially sign the Gen IV collaboration agreements with the U.S. 
DEVELOPMENT OF A CONTROLLED MATERIAL SPECIFICATION FOR ALLOY 617 FOR NUCLEAR APPLICATIONS

Table 9. Recommended Tentative Chemical Composition of Alloy 617 for VHTR Materials Testing

\begin{tabular}{|c|c|c|c|c|c|c|c|c|c|c|c|c|c|c|c|c|}
\hline Heat & $\mathrm{Ni}$ & $\mathrm{Cr}$ & Co & Мo & $\mathrm{Nb}$ & $\mathrm{Fe}$ & $\mathrm{Mn}$ & $\mathrm{Al}$ & $\mathrm{C}$ & $\mathrm{Cu}$ & $\mathrm{Si}$ & $\mathrm{S}$ & $\mathrm{Ti}$ & $\mathrm{P}$ & B & $\mathrm{N}$ \\
\hline ASTM Min & 44.5 & 20.0 & 10.0 & 8.0 & - & - & - & 0.8 & 0.05 & - & - & - & - & - & - & - \\
\hline ASTM Max & - & 24.0 & 15.0 & 10.0 & - & 3.0 & 1.0 & 1.5 & 0.15 & 0.5 & 1.0 & 0.015 & 0.6 & - & 0.006 & - \\
\hline CCA 617 Min & & 21.0 & 11.0 & 8.0 & & & & 0.80 & 0.05 & & & & 0.30 & & 0.002 & \\
\hline CCA 617 Max & & 23.0 & 13.0 & 10.0 & & 1.5 & 0.30 & 1.30 & 0.08 & 0.05 & 0.3 & 0.008 & 0.50 & 0.012 & 0.005 & 0.050 \\
\hline GenIV617 Min & 44.5 & 22.0 & 13.0 & 9.0 & & & & 1.20 & $\mathbf{0 . 0 7}$ & & & & 0.40 & & 0.002 & \\
\hline GenIV617 Max & & 24.0 & 15.0 & 10.0 & & 1.0 & 1.0 & 1.40 & 0.10 & 0.2 & 0.3 & 0.008 & 0.60 & 0.010 & 0.005 & 0.040 \\
\hline
\end{tabular}


2. Actions should be taken to gain a complete understanding of the correlation between the high temperature properties and the strengthening mechanisms of the alloy. Currently, such work is being conducted under the Fossil Energy Advanced Research Materials Program for a target temperature of $760^{\circ} \mathrm{C}\left(1400^{\circ} \mathrm{F}\right)$ for the Ultrasupercritical Steam Boilers. Collaboration should be initiated with the fossil program to investigate the possibility of retaining $\gamma^{\prime}$ and the other strengthening precipitates at the temperature range of interest to the VHTR applications.

3. Computational modeling should be conducted on the prediction of the second phases at temperatures and times of interest to the VHTR applications. The modeling results will provide guidance for further refining the specification, or systematically designing metallurgical experiments for refining the specification.

4. The high creep strength of CCA 617 should be further verified with more tests. Figures 7 shows that there are very limited data points to support the suggestion that the heat offer higher creep strength around $700^{\circ} \mathrm{C}\left(1292^{\circ} \mathrm{F}\right)$. A review of Figure 8 indicates that if the test of the lowest point at $1050^{\circ} \mathrm{C}\left(1922^{\circ} \mathrm{F}\right)$ had not been conducted, the data pattern in Figure 8 would have given a false impression of high creep strength at temperatures above $950^{\circ} \mathrm{C}\left(1742^{\circ} \mathrm{F}\right)$.

5. If necessary, metallurgical experiments should be conducted to investigate the effects of the variations in $\mathrm{Al}, \mathrm{Ti}, \mathrm{C}, \mathrm{Mo}, \mathrm{Co}, \mathrm{B}$, and $\mathrm{N}$ on properties of the alloy on a well designed systematical basis with the guidance from the computational modeling.

It should be pointed out that if action No. 5 is considered necessary, the refining process may need to be iterated until satisfactory results are yielded or conclusions are drawn with sufficient experiment support. The possibility can not be ruled out that in reaching for significantly improved properties the iterations may carry the search beyond the limits of the standard specifications, which implies that the specification refinement is being turned into an alloy modification or development effort. Once the iteration is started, long cycles of manufacturing, testing, and analyses should be expected. Therefore, a managerial decision will have to be made based on the required timeframe and funding availability. Experience shows that such a process usually takes several years.

\section{REFERENCES}

[1] Corum, J.M. and Blass, J. J., "Rules for Design of Alloy 617 Nuclear Components to Very High Temperatures," pp. 147-153, PVP - Vol. 215, Fatigue, Fracture, and Risk, Am. Soc. of Mechanical Engineers, 1991. 
DEVELOPMENT OF A CONTROLLED MATERIAL SPECIFICATION FOR ALLOY 617 FOR NUCLEAR APPLICATIONS

[2] Schubert, F., Breitbach, G. and Nickel, H., "German Structural Design Rule KTA 3221 for Metallic HTR-Components,” pp. 9-18, PVP-Vol. 262, High-Temperature Service and Time-Dependent Failure, Am. Soc. of Mechanical Engineers, 1993.

[3] Task Force Very High-Temperature Design, "Draft Alloy 617 Code Case”, Case N47-28, Class 1 Components in Elevated Temperature Service, Section III, Division 1, July 27, 1988.

[4] Ennis, F. J., Mohr, K. P. and Schuster, H., "Effect of Carburizing Service Environments on the Mechanical Properties of High-Temperature Alloys”, pp. 363 - 368, Vol. 66, Nuclear Technology, August, 1984.

[5] Schubert, F., Bruch, U., Cook, R., Diehl, H., Ennis, P. L., Jakobeit, W., Penkalla, H. J., Heesen, E. and Ullrich, G., "Creep Rupture Behavior of Candidate Materials for Nuclear Process Heat Applications”, pp. 227-240, Vol. 66, Nuclear Technology, August 1984.

[6] The Special Metals, email communication with W. Ren, March 28, 2005.

[7] McCoy, H. E., February, "Evaluation of Advanced Alloys for Gas-Cooled Reactors”, HTGR-85-158, ORNL/TM-9891, Oak Ridge National Laboratory, 1986.

[8] Goff, S. D., and Billot, P., "Review of Existing Data Base and R\&D in Support of Codes and Standard Development”, Gen IV International Forum PMB Meeting, Oak Ridge, TN, April, 2005.

[9] Santella, M. L., private communication, 2005.

[10] Mankins, W. L., Hosier, J. C. and Bassford, T. H., "Microstructure and Phase Stability of INCONEL Alloy 617,” Metallurgical Transactions, 5, pp. 2579-2590, 1974.

[11] Kimball, G. F., Lai, G. Y. and Reynolds, G. H., "Effects of Thermal Aging on Microstructural and Mechanical Properties of a Commercial Ni-Cr-Co-Mo Alloy (Inconel 617),” Metallurgical Transactions, 7A, pp. 1951-1952, 1976.

[12] Kihara, S., Newkirk, J. B., Ohtomo, A. and Saiga, Y., "Morphological Changes of Carbides During Creep and Their Effects on the Creep Properties of Inconel 617 at 1000C,” Metallurgical Transactions, 11A, pp. 1019-1031, 1980.

[13] Kirchhofer, H., Schubert, F. and Nickel, H., "Precipitation Behavior of Ni-Cr-22Fe18Mo (HASTELLOY X) and Ni-Cr-2Co-12Mo (INCONEL 617) after Isothermal Aging”, Nuclear Technology, 66, pp. 139-148, 1984. 
DEVELOPMENT OF A CONTROLLED MATERIAL SPECIFICATION FOR ALLOY 617 FOR NUCLEAR APPLICATIONS

[14] Wu, Q. and Vasudevan, V. K., "Characterization of Boiler Materials for Ultracritical Coal Power Plants," Annual Progress Report for Period August 1, 2002 to July 30, 2003 under UT-Battelle Sub Contract Number 4000017043, 2004.

[15] Personal communication between R. W. Swindeman and D. Roberts of General Atomics.

[16] Shingledecker, J. P., Swindeman, R. W., Wu, Q. and Vasudevan, V. K., "Creep Strength of High-Temperature Alloys for Ultrasupercritical Steam Boilers", Proceedings to the Fourth International Conference on advances in Materials Technology for Fossil Power Plants, Hilton Head, SC, October 25 - 28, 2004.

[17] Decker, R. F., "Strengthening Mechanisms in Nickel-Base Superalloys,” pp. 147170 in Symposium: Steel Strengthening Mechanism, Climax Molybdenum Company, Greenwich CN, 1969.

[18] Miodownik, A. P., Li, X., Saunders, N., and Schille, J. -Ph., "Modelling of Creep in Nickel Based Superalloys,” pp. 779-788 in Parsons 2003 Engineering Issues in Turbin Machinery, Power Plant and Renewables, - Proceedings of the Sixth International Charles Parsons Turbine Conference, Trinity College, Dublin Ireland, September 16-18, 2003.

[19] Starr, F. and Shibli, I. A., "Fundamental Issues in the Development of Austenitic vans Nickel Based Alloys for Advanced Supercritical Steam and High Temperature Indirect Fired Gas Turbine systems”, pp. 459-471, in Parsons 2000 Advanced Materials for 21 Century Turbines and Power Plant, Proceedings of the Fifth International Charles Parsons Turbine Conference, Churchill College, Cambridge UK, July 3-7, 2000. 
DEVELOPMENT OF A CONTROLLED MATERIAL

SPECIFICATION FOR ALLOY 617 FOR NUCLEAR APPLICATIONS

\section{APPENDIX A}

ASTM Standard Specification for Alloy 617 


\title{
DEVELOPMENT OF A CONTROLLED MATERIAL SPECIFICATION FOR ALLOY 617 FOR NUCLEAR APPLICATIONS
}

Designation: B $168-01$

An American National Standard Used in USDOE-NE Standards

\section{Standard Specification Nickel-Chromium-Iron Alloys (UNS N06600, N06601, N06603, N06690, N06693, N06025, and N06045) and Nickel- Chromium-Cobalt-Molybdenum Alloy (UNS N06617) Plate, Sheet, and Strip ${ }^{1}$}

\begin{abstract}
This standard is issued under the fixed designation B 168; the number immediately following the designation indicates the year of original adoption or, in the case of revision, the year of last revision. A number in parentheses indicates the year of last reapproval. A superscript epsilon $(\epsilon)$ indicates an editorial change since the last revision or reapproval.
\end{abstract}

This standard has been approved for use by agencies of the Department of Defense.

\section{Scope}

1.1 This specification ${ }^{2}$ covers rolled nickel-chromium-iron alloys (UNS N06600, N06601, N06603, N06690, N06693, $\mathrm{N} 06025$, and N06045)* and nickel-chromium-cobaltmolybdenum alloy (UNS N06617) plate, sheet, and strip.

1.2 The values stated in inch-pound units are to be regarded as the standard. The values given in parentheses are for information only.

1.3 The following precautionary caveat pertains only to the test methods portion, Section 12, of this specification: This standard does not purport to address all of the safety concerns, if any, associated with its use. It is the responsibility of the user of this standard to establish appropriate safety and health practices and determine the applicability of regulatory limitations prior to use.

\section{Referenced Documents}

2.1 ASTM Standards:

B 166 Specification for Nickel-Chromium-Iron Alloys (UNS N06600, N06601, N06603, N06690, N06693, N06025, and N06045) and Nickel-Chromium-CobaltMolybdenum Alloy (UNS N06617) Rod, Bar, and Wire ${ }^{3}$

B 880 Specification for General Requirements for Chemical Check Analysis Limits for Nickel, Nickel Alloys and Cobalt Alloys ${ }^{3}$

E 8 Test Methods for Tension Testing of Metallic Materials ${ }^{4}$ E 10 Test Method for Brinell Hardness of Metallic Materials $^{4}$

E 18 Test Methods for Rockwell Hardness and Rockwell

\footnotetext{
${ }^{1}$ This specification is under the jurisdiction of ASTM Committee B02 on Nonferrous Metals and Alloys and is the direct responsibility of Subcommittee B02.07 on Refined Nickel and Cobalt and Their Alloys.

Current edition approved Nov. 10, 2001. Published January 2002. Originally published as B $168-41$. Last previous edition B $168-00$.

${ }^{2}$ For ASME Boiler and Pressure Code applications, see related Specification SB-168 in Section II of that Code.

* New designation established in accordance with Practice E 527 and SAE J1086, Practice for Numbering Metals and Alloys (UNS).

${ }^{3}$ Annual Book of ASTM Standards, Vol 02.04 .

${ }^{4}$ Annual Book of ASTM Standards, Vol 03.01.
}

Superficial Hardness of Metallic Materials ${ }^{4}$

E 29 Practice for Using Significant Digits in Test Data to Determine Conformance with Specifications ${ }^{5}$

E 38 Methods for Chemical Analysis of Nickel-Chromium and Nickel-Chromium-Iron Alloys ${ }^{6}$

E 112 Test Methods for Determining the Average Grain $\mathrm{Size}^{4}$

E 140 Hardness Conversion Tables for Metals ${ }^{4}$

E 1473 Test Methods for Chemical Analysis of Nickel, Cobalt, and High-Temperature Alloys ${ }^{7}$

F 155 Test Method for Temper of Strip and Sheet Metals for Electronic Devices (Spring-Back Method) ${ }^{8}$

2.2 Federal Standards: ${ }^{9}$

Fed. Std. No. 102 Preservation, Packaging and Packing Levels

Fed. Std. No. 123 Marking for Shipment (Civil Agencies) Fed. Std. No. 182 Continuous Identification Marking of Nickel and Nickel-Base Alloys

2.3 Military Standard: ${ }^{9}$

MIL-STD-129 Marking for Shipment and Storage

\section{Terminology}

3.1 Descriptions of Terms Specific to This Standard-The terms given in Table 1 shall apply.

\section{Ordering Information}

4.1 It is the responsibility of the purchaser to specify all requirements that are necessary for the safe and satisfactory performance of material ordered under this specification. Examples of such requirements include, but are not limited to, the following:

4.1.1 Alloy - Name or UNS number (see Table 2),

4.1.2 ASTM designation, including year of issue,

\footnotetext{
${ }^{5}$ Annual Book of ASTM Stondards, Vol 14.02

${ }^{6}$ Discontinued; see 1989 Annual Book of ASTM Standards, Vol 03.05.

${ }^{7}$ Annual Book of ASTM Standards, Vol 03.05 .

${ }^{8}$ Discontinued; see 1983 Annual Book of ASTM Standards, Vol 10.04.

${ }^{9}$ Available from Standardization Documents Order Desk, Bldg. 4 Section D, 700 Robbins Ave., Philadelphia, PA 19111-5094, Attn: NPODS.
} 


\section{DEVELOPMENT OF A CONTROLLED MATERIAL SPECIFICATION FOR ALLOY 617 FOR NUCLEAR APPLICATIONS}

\begin{tabular}{|c|c|c|c|c|c|c|c|c|}
\hline \multicolumn{9}{|c|}{ A可的 B 168} \\
\hline \multicolumn{2}{|l|}{ Product } & \multicolumn{5}{|c|}{ Thickness, in. (mm) } & \multicolumn{2}{|c|}{ Width, in. (mm) } \\
\hline \multicolumn{2}{|c|}{$\begin{array}{l}\text { Hot-rolled plate }{ }^{A} \\
\text { Hot-rolled sheet } \\
\text { Cold-rolled sheet }^{C} \\
\text { Cold-rolled strip }\end{array}$} & \multicolumn{4}{|c|}{$\begin{array}{l}3 / 16 \text { and over (Table } 5 \text { and Table } 6 \text { ) } \\
0.018 \text { to } 0.250(0.46 \text { to } 6.4) \text {, incl (Table } 7) \\
0.018 \text { to } 0.250(0.46 \text { to } 6.4) \text {, incl (Table } 7) \\
0.005 \text { to } 0.250(0.13 \text { to } 6.4) \text {, incl (Table } 7)\end{array}$} & & $\begin{array}{l}\text { (Table } 8) \\
\text { (Table 10 } \\
\text { (Table } 10 \\
\text { (Table } 10\end{array}$ & \\
\hline \multicolumn{9}{|c|}{$\begin{array}{l}{ }^{A} \text { Material } 3 / 16 \text { to } 1 / 4 \text { in. }(4.8 \text { to } 6.4 \mathrm{~mm}) \text {, incl, in thickness may be furnished as sheet or plate provided the material meets the specification requirements for the conditio } \\
\text { ordered. } \\
\left.{ }^{B} \text { Hot-rolled plate, in widths } 10 \mathrm{in} \text {. ( } 254 \mathrm{~mm}\right) \text { and under, may be furnished as hot-finished rectangles with sheared or cut edges in accordance with Specification B } 166 \\
\text { provided the mechanical property requirements of this specification are met. } \\
{ }^{C} \text { Material under } 48 \mathrm{in.}(1219 \mathrm{~mm}) \text { in width may be furnished as sheet or strip provided the material meets the specification requirements for the condition ordered. }\end{array}$} \\
\hline Element & \multicolumn{8}{|c|}{ Composition Limits, $\%$} \\
\hline $\begin{array}{l}\text { Nickel } \\
\text { Chromium }\end{array}$ & $\begin{array}{l}72.0 \mathrm{~min} \\
14.0-17.0\end{array}$ & $\begin{array}{l}58.0-63.0 \\
21.0-25.0\end{array}$ & $\begin{array}{l}44.5 \mathrm{~min} \\
20.0-24.0\end{array}$ & $\begin{array}{l}58.0 \mathrm{~min} \\
27.0-31.0\end{array}$ & $\begin{array}{l}\text { remainder }^{A} \\
27.0-31.0\end{array}$ & $\begin{array}{l}\text { remainder }^{A} \\
24.0-26.0\end{array}$ & $\begin{array}{l}45.0 \mathrm{~min} \\
26.0-29.0\end{array}$ & $\begin{array}{l}\text { remainder }^{A} \\
24.0-26.0\end{array}$ \\
\hline Cobalt & $\begin{array}{l}14.0-11.0 \\
\ldots\end{array}$ & $\begin{array}{l}21.0-20.0 \\
\ldots\end{array}$ & $10.0-15.0$ & ... & & ... & $\ldots$ & $\ldots$ \\
\hline Molybdenum & $\cdots$ & $\cdots$ & $8.0-10.0$ & $\cdots$ & $\ldots$ & $\cdots$ & $\cdots$ & $\cdots$ \\
\hline Niobium & $\ldots$ & $\ldots$ & $\ldots$ & $\ldots$ & $0.5-2.5$ & $\ldots$ & $\ldots$ & $\ldots$ \\
\hline Iron & $6.0-10.0$ & remainder ${ }^{A}$ & $3.0 \max$ & $7.0-11.0$ & $2.5-6.0$ & $8.0-11.0$ & $21.0-25.0$ & $8.0-11.0$ \\
\hline Manganese & $1.0 \max$ & $1.0 \max$ & $1.0 \max$ & $0.5 \max$ & $1.0 \max$ & $0.15 \max$ & $1.0 \max$ & $0.15 \max$ \\
\hline Aluminum & ... & $1.0-1.7$ & $0.8-1.5$ & ... & $2.5-4.0$ & $1.8-2.4$ & ... & $2.4-3.0$ \\
\hline Carbon & $0.15 \max$ & $0.10 \max$ & $0.05-0.15$ & $0.05 \max$ & $0.15 \max$ & $0.15-0.25$ & $0.05-0.12$ & $0.20-0.40$ \\
\hline Copper & $0.5 \max$ & $1.0 \max$ & $0.5 \max$ & $0.5 \max$ & $0.5 \max$ & $0.1 \max$ & $0.3 \max$ & $0.50 \max$ \\
\hline Silicon & $0.5 \max$ & $0.5 \max$ & $1.0 \mathrm{max}$ & $0.5 \max$ & $0.5 \max$ & $0.5 \max$ & $2.5-3.0$ & $0.50 \max$ \\
\hline Sulfur & $0.015 \max$ & $0.015 \max$ & $0.015 \max$ & $0.015 \max$ & $0.01 \max$ & $0.010 \max$ & $0.010 \max$ & $0.010 \max$ \\
\hline Titanium & ... & ... & $0.6 \max$ & ... & $1.0 \max$ & $0.1-0.2$ & & $0.01-0.25$ \\
\hline Phosphorus & $\ldots$ & $\begin{array}{l}\cdots \\
\cdots\end{array}$ & ... & $\begin{array}{l}\cdots \\
\cdots\end{array}$ & & 0.020 max & $0.020 \max$ & $0.020 \max$ \\
\hline Zirconium & $\begin{array}{l}\cdots \\
\ldots\end{array}$ & $\begin{array}{l}\cdots \\
\ldots\end{array}$ & $\begin{array}{l}\cdots \\
\ldots\end{array}$ & $\begin{array}{l}\cdots \\
\cdots\end{array}$ & & $0.01-0.10$ & & $0.01-0.10$ \\
\hline Yttrium & $\ldots$ & $\ldots$ & .. & $\begin{array}{l}\cdots \\
\ldots\end{array}$ & & $0.05-0.12$ & & $0.01-0.15$ \\
\hline Boron & $\begin{array}{l}\cdots \\
\ldots\end{array}$ & $\cdots$ & $0.006 \max$ & $\cdots$ & & ... & $\ldots$ & ... \\
\hline Nitrogen & $\ldots$ & $\ldots$ & $\ldots$ & $\ldots$ & & $\ldots$ & $\ldots$ & $\ldots$ \\
\hline
\end{tabular}

${ }^{A}$ Element shall be determined arithmetically by difference.

4.1.3 Condition-See 6.1 and 6.2 and Appendix X1,

4.1.4 Finish-Appendix X1,

4.1.5 Dimensions - Thickness, width, and length,

4.1.6 Quantity,

4.1.7 Optional Requirements:

4.1.7.1 Sheet and Strip - Whether to be furnished in coil, in cut straight lengths, or in random straight lengths,

4.1.7.2 Strip-Whether to be furnished with commercial slit edge, square edge, or round edge,

4.1.7.3 Plate-Whether to be furnished specially flattened (see 7.7.2); also how plate is to be cut (see 7.2.1 and 7.3.2),

4.1.8 Certification - State if certification or a report of test results is required (Section 15),

4.1.9 Samples for Product (Check) Analysis-Whether samples for product (check) analysis should be furnished (see 5.2), and

4.1.10 Purchaser Inspection-If the purchaser wishes to witness tests or inspection of material at the place of manufacture, the purchase order must so state indicating which tests or inspections are to be witnessed (Section 13).

\section{Chemical Composition}

5.1 The material shall conform to the requirements as to chemical composition prescribed in Table 2 .

5.2 If a product (check) analysis is performed by the purchaser, the material shall conform to the product (check) analysis variations prescribed in Specification B 880 .

\section{Mechanical Properties and Other Requirements}

6.1 Mechanical Properties-The material shall conform to the mechanical properties prescribed in Table 3 .

TABLE 3 Mechanical Properties for Plate, Sheet, and Strip (All Thicknesses and Sizes Unless Otherwise Indicated)

\begin{tabular}{|c|c|c|c|c|}
\hline Condition (Temper) & Tensile Strength, min, psi (MPa) & $\begin{array}{c}\text { Yield Strength }{ }^{A}(0.2 \% \text { offset }), \text { min, psi } \\
(\mathrm{MPa})\end{array}$ & $\begin{array}{l}\text { Elongation in } 2 \text { in. or } 50 \mathrm{~mm} \\
\text { (or } 4 D \text { ), } \mathrm{min}, \%\end{array}$ & Rockwell Hardness ${ }^{B, C}$ \\
\hline \multicolumn{5}{|c|}{ Hot-Rolled Plate } \\
\hline \multicolumn{5}{|l|}{ UNS N06600: } \\
\hline Annealed & $80000(550)$ & $35000(240)$ & 30 & $\ldots$ \\
\hline As-rolled ${ }^{D, E}$ & $85000(586)$ & $35000(240)$ & 30 & $\ldots$ \\
\hline \multicolumn{5}{|l|}{ UNS N06601: } \\
\hline Annealed & $80000(550)$ & $30000(205)$ & 30 & $\ldots$ \\
\hline
\end{tabular}




\section{DEVELOPMENT OF A CONTROLLED MATERIAL SPECIFICATION FOR ALLOY 617 FOR NUCLEAR APPLICATIONS}

\begin{tabular}{|c|c|c|c|c|}
\hline \multicolumn{5}{|c|}{ 驾荝 B 168} \\
\hline Condition (Temper) & Tensile Strength, min, psi $(\mathrm{MPa})$ & $\begin{array}{c}\text { Yield Strength }{ }^{A}(0.2 \% \text { offset), min, psi } \\
(\mathrm{MPa})\end{array}$ & $\begin{array}{l}\text { Elongation in } 2 \text { in. or } 50 \mathrm{~mm} \\
\text { (or } 4 \mathrm{D} \text { ), } \mathrm{min}, \%\end{array}$ & Rockwell Hardness ${ }^{B, C}$ \\
\hline UNS N06603: & & & & \\
\hline $\begin{array}{l}\text { Annealed } \\
\text { An }\end{array}$ & $94000(650)$ & $43000(300)$ & 25 & $\ldots$ \\
\hline $\begin{array}{l}\text { Annealed } \\
\text { UNS N06690: }\end{array}$ & $95000(655)$ & $35000(240)$ & 35 & $\ldots$ \\
\hline Annealed & $85000(586)$ & $35000(240)$ & 30 & $\ldots$ \\
\hline As-rolled ${ }^{D, E}$ & $85000(586)$ & $35000(240)$ & 30 & $\ldots$ \\
\hline Annealed $^{F}$ & $75000(514)$ & $30000(206)$ & 30 & $\cdots$ \\
\hline UNS N06693 & & & & \\
\hline $\begin{array}{l}\text { Annealed } \\
\text { UNS N06025 }\end{array}$ & $85000(586)$ & $40000(275)$ & 30 & $\ldots$ \\
\hline $\begin{array}{l}\text { Annealed } \\
\text { UNS N06045 }\end{array}$ & $98000(680)$ & $39000(270)$ & 30 & $\ldots$ \\
\hline Annealed & $90000(620)$ & $35000(240)$ & 35 & $\ldots$ \\
\hline \multicolumn{5}{|c|}{ Hot-Rolled Sheet } \\
\hline $\begin{array}{l}\text { UNS N06600: } \\
\text { Annealed }\end{array}$ & $80000(550)$ & $35000(240)$ & 30 & $\ldots$ \\
\hline UNS N06601: & & & & \\
\hline $\begin{array}{l}\text { Annealed } \\
\text { UNS N06603: }\end{array}$ & $80000(550)$ & $30000(205)$ & 30 & $\ldots$ \\
\hline $\begin{array}{l}\text { Annealed } \\
\text { UNS N06617: }\end{array}$ & $94000(650)$ & $43000(300)$ & 25 & $\ldots$ \\
\hline $\begin{array}{l}\text { Annealed } \\
\text { UNS N06690: }\end{array}$ & $95000(655)$ & $35000(240)$ & 30 & $\ldots$ \\
\hline $\begin{array}{l}\text { Annealed } \\
\text { UNS N06693 }\end{array}$ & $85000(586)$ & $35000(240)$ & 30 & $\ldots$ \\
\hline $\begin{array}{l}\text { Annealed } \\
\text { UNS N06025 }\end{array}$ & $85000(586)$ & $40000(275)$ & 30 & $\ldots$ \\
\hline Annealed & $98000(680)$ & $39000(270)$ & 30 & $\ldots$ \\
\hline $\begin{array}{l}\text { UNS N06045 } \\
\text { Annealed }\end{array}$ & $90000(620)$ & $35000(240)$ & 35 & $\ldots$ \\
\hline \multicolumn{5}{|c|}{ Cold-Rolled Plate } \\
\hline UNS N06603 & & & & \\
\hline $\begin{array}{l}\text { Annealed } \\
\text { UNS N06025 }\end{array}$ & $94000(650)$ & $43000(300)$ & 25 & $\ldots$ \\
\hline Annealed & $98000(680)$ & $39000(270)$ & 30 & $\ldots$ \\
\hline Annealed & $90000(620)$ & $35000(240)$ & 35 & $\ldots$ \\
\hline \multicolumn{5}{|c|}{ Cold-Rolled Sheet } \\
\hline UNS N06600: & & & & \\
\hline Annealed & $80000(550)^{6}$ & $35000(240)$ & $30^{6}$ & $\ldots$ \\
\hline Hard & $125000(860)^{6}$ & $90000(620)$ & $2^{G}$ & $\ldots$ \\
\hline UNS N06601: & & & & \\
\hline $\begin{array}{l}\text { Annealed } \\
\text { UNS N06603: }\end{array}$ & $80000(550)^{G}$ & $30000(205)$ & $30^{G}$ & $\ldots$ \\
\hline Annealed & $94000(650)$ & $43000(300)$ & $25^{G}$ & $\ldots$ \\
\hline UNS N06617: & & & & \\
\hline $\begin{array}{l}\text { Annealed } \\
\text { UNS N06690: }\end{array}$ & $95000(655)^{G}$ & $35000(240)$ & $25^{G}$ & $\ldots$ \\
\hline Annealed & $85000(586)^{G}$ & $35000(240)$ & $30^{G}$ & $\ldots$ \\
\hline Hard & $125000(860)^{6}$ & $90000(620)$ & $2^{G}$ & $\ldots$ \\
\hline UNS N06693 & & & & \\
\hline Annealed & 85000 (586) & $40000(275)$ & 30 & $\ldots$ \\
\hline UNS N06025 & & & & \\
\hline $\begin{array}{l}\text { Annealed } \\
\text { UNS N06045 }\end{array}$ & $98000(680)$ & $39000(270)$ & 30 & $\ldots$ \\
\hline Annealed & $90000(620)$ & $35000(240)$ & 35 & $\ldots$ \\
\hline \multicolumn{5}{|c|}{ Cold-Rolled Strip } \\
\hline UNS N06600: & & & & \\
\hline Annealed & $80000(550)^{G}$ & $35000(240)$ & $30^{G}$ & $\ldots$ \\
\hline Skin-hard & $\ldots$ & $\ldots$ & $\ldots$ & B 85 to $B 88$ \\
\hline Quarter-hard & $\ldots$ & $\ldots$ & $\ldots$ & B 88 to $B 94$ \\
\hline Half-hard & $\ldots$ & $\ldots$ & $\ldots$ & B 93 to B98 \\
\hline Three-quarter-hard & $\ldots$ & $\ldots$ & & B 97 to $\mathrm{C} 25$ \\
\hline Hard & $125000(860)^{G}$ & $90000(620)$ & $2^{6}$ & \\
\hline Spring & $\ldots$ & $\ldots$ & $\ldots$ & C $30 \mathrm{~min}$ \\
\hline $\begin{array}{l}\text { UNS N06601: } \\
\text { Annealed }\end{array}$ & $80000(550)^{G}$ & $30000(205)$ & $30^{G}$ & \\
\hline
\end{tabular}




\section{DEVELOPMENT OF A CONTROLLED MATERIAL SPECIFICATION FOR ALLOY 617 FOR NUCLEAR APPLICATIONS}

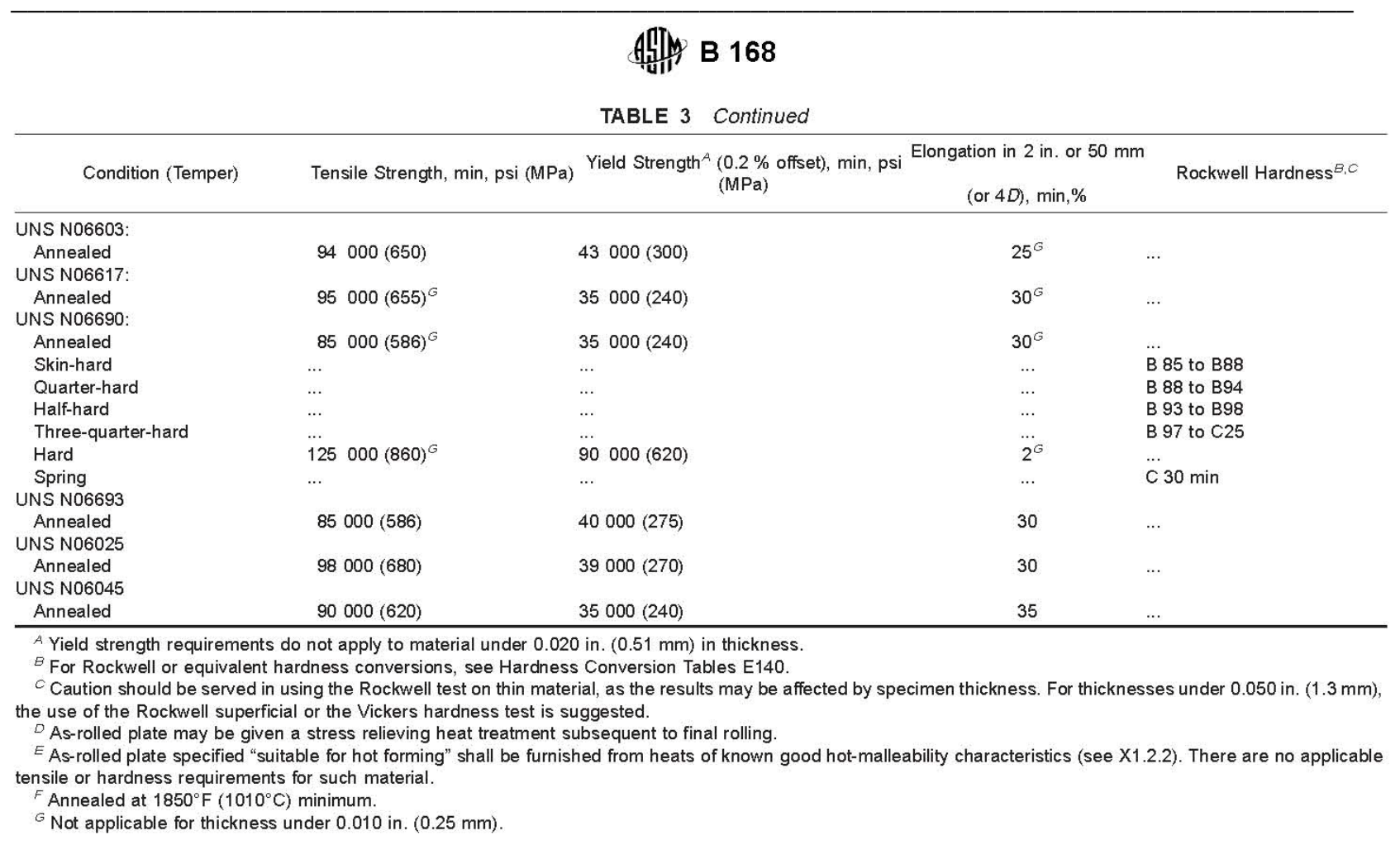

6.2 Deep Drawing and Spinning Quality Sheet and StripThe material shall conform to the grain size and hardness requirements as prescribed in Table 4 .

6.2.1 The mechanical properties of Table 3 do not apply to deep drawing and spinning quality sheet and strip.

\section{Dimensions and Permissible Variations}

7.1 Thickness and Weight:

7.1.1 Plate - For plate up to 2 in. $(50.8 \mathrm{~mm})$, inclusive, in

TABLE 4 Grain Size and Hardness for Cold-Rolled, DeepDrawing, and Spinning-Quality Sheet and Strip

\begin{tabular}{|c|c|c|c|}
\hline $\begin{array}{l}\text { Thickness, in. } \\
(\mathrm{mm})\end{array}$ & $\begin{array}{c}\text { Calculated } \\
\text { Diameter of } \\
\text { Average Grain } \\
\text { Section, max, in. } \\
(\mathrm{mm})\end{array}$ & $\begin{array}{l}\text { Corresponding } \\
\text { ASTM } \\
\text { MicroGrain } \\
\text { Size No. }\end{array}$ & $\begin{array}{l}\text { Rockwell } B^{A, B} \\
\text { Hardness, max }\end{array}$ \\
\hline \multicolumn{4}{|c|}{ Sheet (56 in. (1.42 m) Wide and Under) } \\
\hline $0.050(1.3)$ and less & $0.0030(0.075)$ & 4.5 & 86 \\
\hline $\begin{array}{l}\text { Over } 0.050 \text { to } 0.250 \\
(1.3 \text { to } 6.4) \text {, incl }\end{array}$ & $0.0043(0.110)$ & 3.5 & 86 \\
\hline \multicolumn{4}{|c|}{ Strip $(12 \text { in. }(305 \mathrm{~mm}) \text { Wide and Under })^{C}$} \\
\hline $\begin{array}{l}0.005^{D} \text { to } 0.010 \\
(0.13 \text { to } 0.25) \\
\text { incl }\end{array}$ & $0.0009(0.022)$ & $8^{E}$ & $88^{E}$ \\
\hline $\begin{array}{l}\text { Over } 0.010 \text { to } 0.125 \\
(0.25 \text { to } 3.2) \text {, incl }\end{array}$ & $0.0030(0.075)$ & 4.5 & 86 \\
\hline
\end{tabular}

${ }^{A}$ For Rockwell or equivalent hardness conversions, see Hardness Conversion Tables E140.

${ }^{B}$ Caution should be observed in using the Rockwell test on thin material, as the results may be affected by specimen thickness. For thicknesses under 0.050 in. $(1.3 \mathrm{~mm})$, the use of the Rockwell superficial or the Vickers hardness test is suggested.

${ }^{c}$ Sheet requirements (above) apply to strip thicknessess over 0.125 in. (3.2 $\mathrm{mm}$ ), and for all thicknessess of strip over $12 \mathrm{in.}(305 \mathrm{~mm})$ in width.

$D$ For ductility evaluations for strip under $0.005 \mathrm{in} .(0.13 \mathrm{~mm})$ in thickness, the springback test, such as described in Test Method F 155, is often used and the manufacturer should be consulted.

E Accurate grain size and hardness determinations are difficult to make on strip under $0.005 \mathrm{in} .(0.13 \mathrm{~mm})$ in thickness and are not recommended. thickness, the permissible variation under the specified thickness and permissible excess in overweight shall not exceed the amounts prescribed in Table 5.

7.1.1.1 For use with Table 5, plate shall be assumed to weigh $0.304 \mathrm{lb} /$ in. $^{3}\left(8.415 \mathrm{~g} / \mathrm{cm}^{3}\right)$.

7.1.2 Plate-For plate over $2 \mathrm{in.}(50.8 \mathrm{~mm})$ in thickness, the permissible variations over the specified thickness shall not exceed the amounts prescribed in Table 6.

7.1.3 Sheet and Strip - The permissible variations in thickness of sheet and strip shall be as prescribed in Table 7. The thickness of strip and sheet shall be measured with the micrometer spindle $3 / 8 \mathrm{in}$. $(9.5 \mathrm{~mm}$ ) or more from either edge for material $1 \mathrm{in.}(25.4 \mathrm{~mm})$ or over in width and at any place on the strip under $1 \mathrm{in.}$ in width.

7.2 Width or Diameter.

7.2.1 Plate-The permissible variations in width of rectangular plates and diameter of circular plates shall be as prescribed in Table 8 and Table 9.

7.2.2 Sheet and Strip - The permissible variations in width for sheet and strip shall be as prescribed in Table 10 .

\subsection{Length:}

7.3.1 Sheet and strip of all sizes may be ordered to cut lengths, in which case a variation of $1 / 8$ in. $(3.2 \mathrm{~mm})$ over the specified length shall be permitted.

7.3.2 Permissible variations in length of rectangular plate shall be as prescribed in Table 11 .

7.4 Straightness:

7.4.1 The edgewise curvature (depth of chord) of flat sheet, strip, and plate shall not exceed 0.05 in. multiplied by the length in feet $(0.04 \mathrm{~mm}$ multiplied by the length in centimetres).

7.4.2 Straightness for coiled material is subject to agreement between the manufacturer and the purchaser. 


\section{DEVELOPMENT OF A CONTROLLED MATERIAL SPECIFICATION FOR ALLOY 617 FOR NUCLEAR APPLICATIONS}

\section{B 168}

\section{TABLE 5 Permissible Variations in Thickness and Overweight of Rectangular Plates}

NoTe 1 -All plates shall be ordered to thickness and not to weight per square foot $(\mathrm{cm})$. No plates shall vary more than $0.01 \mathrm{in} .(0.3 \mathrm{~mm}) \mathrm{under}$ the thickness ordered, and the overweight of each $1 \mathrm{t}^{A}$ in each shipment shall not exceed the amount in the table. Spot grinding is permitted to remove surface imperfections, such spots not to exceed 0.01 in. under the specified thickness.

\begin{tabular}{|c|c|c|c|c|c|c|c|c|c|c|}
\hline \multirow[b]{2}{*}{$\begin{array}{l}\text { Specified Thickness, } \\
\text { in. }(\mathrm{mm})\end{array}$} & \multicolumn{10}{|c|}{$\begin{array}{c}\text { Permissible Excess in Average Weight }{ }^{B, C} \text { per Square Foot of Plates for Widths Given in Inches (Millimetres) Expressed in } \\
\text { Percentage of Nominal Weights }\end{array}$} \\
\hline & $\begin{array}{l}\text { Under } 48 \\
(1220)\end{array}$ & $\begin{array}{c}48 \text { to } 60 \\
(1220 \text { to } \\
1520) \\
\text { excl }\end{array}$ & $\begin{array}{c}60 \text { to } 72 \\
(1520 \text { to } \\
1830) \\
\text { excl }\end{array}$ & $\begin{array}{c}72 \text { to } 84 \\
(1830 \text { to } \\
2130) \\
\text { excl }\end{array}$ & $\begin{array}{c}84 \text { to } 96 \\
(2130 \text { to } \\
2440) \\
\text { excl }\end{array}$ & $\begin{array}{l}96 \text { to } 108 \\
(2440 \text { to } \\
2740) \\
\text { excl }\end{array}$ & $\begin{array}{c}108 \text { to } \\
120 \\
(2740 \text { to } \\
3050) \text {, } \\
\text { excl }\end{array}$ & $\begin{array}{c}120 \text { to } \\
132 \\
(3050 \text { to } \\
3350), \\
\text { excl }\end{array}$ & $\begin{array}{c}132 \text { to } \\
144 \\
(3350 \text { to } \\
3660), \\
\text { excl }\end{array}$ & $\begin{array}{c}144 \text { to } \\
160 \\
(3660 \text { to } \\
4070) \text {, } \\
\text { excl }\end{array}$ \\
\hline $3 / 16$ to $5 / 16(4.8$ to 7.9$)$, excl & 9.0 & 10.5 & 12.0 & 13.5 & 15.0 & 16.5 & 18.0 & $\ldots$ & $\ldots$ & $\ldots$ \\
\hline $5 / 16$ to $3 / 8(7.9$ to 9.5$)$, excl & 7.5 & 9.0 & 10.5 & 12.0 & 13.5 & 15.0 & 16.5 & 18.0 & $\ldots$ & $\ldots$ \\
\hline $3 / 8$ to $7 / 16(9.5$ to 11.1$), \mathrm{excl}$ & 7.0 & 7.5 & 9.0 & 10.5 & 12.0 & 13.5 & 15.0 & 16.5 & 18.0 & 19.5 \\
\hline $7 / 16$ to $1 / 2(11.1$ to 12.7$), \mathrm{excl}$ & 6.0 & 7.0 & 7.5 & 9.0 & 10.5 & 12.0 & 13.5 & 15.0 & 16.5 & 18.0 \\
\hline $1 / 2$ to $5 / 8(12.7$ to 15.9$)$, excl & 5.0 & 6.0 & 7.0 & 7.5 & 9.0 & 10.5 & 12.0 & 13.5 & 15.0 & 16.5 \\
\hline $5 / 8$ to $3 / 4(15.9$ to 19.1$)$, excl & 4.5 & 5.5 & 6.0 & 7.0 & 7.5 & 9.0 & 10.5 & 12.0 & 13.5 & 15.0 \\
\hline $3 / 4$ to 1 (19.1 to 25.4$)$, excl & 4.0 & 4.5 & 5.5 & 6.0 & 7.0 & 7.5 & 9.0 & 10.5 & 12.0 & 13.5 \\
\hline 1 to 2 (25.4 to 50.8 ), incl & 4.0 & 4.0 & 4.5 & 5.5 & 6.0 & 7.0 & 7.5 & 9.0 & 10.5 & 12.0 \\
\hline
\end{tabular}

TABLE 6 Permissible Variations in Thickness for Rectangular Plates Over 2 in. $(51 \mathrm{~mm})$ in Thickness

NoTe 1-Permissible variation under specified thickness, 0.01 in. $(0.3 \mathrm{~mm})$

\begin{tabular}{|c|c|c|c|c|c|c|}
\hline \multirow[b]{2}{*}{ Specified Thickness, in. (mm) } & \multicolumn{6}{|c|}{ Permissible Variations, in. $(\mathrm{mm})$, over Specified Thickness for Widths Given, in. $(\mathrm{mm})$} \\
\hline & $\begin{array}{c}\text { To } 36(915) \text {, } \\
\text { excl }\end{array}$ & $\begin{array}{l}36 \text { to } 60 \text { (915 } \\
\text { to } 1520) \text {, excl }\end{array}$ & $\begin{array}{c}60 \text { to } 84 \\
(1520 \text { to } \\
2130 \text { ), excl }\end{array}$ & $\begin{array}{l}84 \text { to } 120 \\
(2130 \text { to } \\
3050) \text {, excl }\end{array}$ & $\begin{array}{l}120 \text { to } 132 \\
\text { (3050 to } \\
3350 \text { ), excl }\end{array}$ & $\begin{array}{c}132(3350) \\
\text { and over }\end{array}$ \\
\hline Over 2 to 3 (51 to 76$)$, excl & $1 / 16(1.6)$ & $3 / 32(2.4)$ & $7 / 64(2.8)$ & $1 / 8(3.2)$ & $1 / 8(3.2)$ & $9 / 64(3.6)$ \\
\hline 3 to 4 (76 to 102$)$, incl & $5 / 64(2.0)$ & $3 / 32(2.4)$ & $7 / 64(2.8)$ & $1 / 8(3.2)$ & $1 / 8(3.2)$ & $9 / 64(3.6)$ \\
\hline
\end{tabular}

\subsection{Edges:}

7.5.1 When finished edges of strip are specified in the contract or order, the following descriptions shall apply:

7.5.1.1 Square-edge strip shall be supplied with finished edges, with sharp, square corners, without bevel or rounding.

7.5.1.2 Round-edge strip shall be supplied with finished edges, semicircular in form, the diameter of the circle forming the edge being equal to the strip thickness.

7.5.1.3 When no description of any required form of strip edge is given, it shall be understood that edges such as those resulting from slitting or shearing will be acceptable.

7.5.1.4 Sheet shall have sheared or slit edges.

7.5.1.5 Plate shall have sheared or cut (machined, abrasivecut, powder-cut, or inert-arc cut) edges, as specified.

7.6 Squareness (Sheet) - For sheets of all thicknesses, the angle between adjacent sides shall be $90 \pm 0.15^{\circ}(1 / 16$ in. in 24 in. $(1.6 \mathrm{~mm}$ in $610 \mathrm{~mm}))$.

7.7 Flatness:

7.7.1 There shall be no flatness requirements for "deepdrawing quality," "spinning quality," or "as rolled" sheet and strip (see X1.4).

7.7.2 Standard flatness tolerances for plate shall conform to the requirements of Table 12 . "Specially flattened" plate, when so specified, shall have permissible variations in flatness as agreed upon between the manufacturer and the purchaser.

\section{Workmanship, Finish, and Appearance}

8.1 The material shall be uniform in quality and temper, smooth, commercially straight or flat, and free of injurious imperfections.
8.2 Sheet, Strip, and Plate - Sheet, strip, and plate supplied in the conditions and finishes as listed in the appendix may be ground or machined to remove surface imperfections, provided such removal does not reduce the material below the minimum specified dimensions. Surface eliminated depressions shall be faired smoothly into the surrounding material. The removal of a surface imperfection shall be verified by the method originally used to detect the imperfection.

\section{Sampling}

\subsection{Lot-Definition:}

9.1.1 A lot for chemical analysis shall consist of one heat.

9.1.2 A lot for mechanical properties, hardness, and grain size testing shall consist of all material from the same heat, nominal thickness, and condition.

9.1.2.1 Where material cannot be identified by heat, a lot shall consist of not more than $500 \mathrm{lb}(227 \mathrm{~kg})$ of material in the same thickness and condition, except for plates weighing over $500 \mathrm{lb}$, in which case only one specimen shall be taken.

\subsection{Test Material Selection:}

9.2.1 Chemical Analysis-Representative samples from each lot shall be taken during pouring or subsequent processing.

9.2.1.1 Product (Check) Analysis shall be wholly the responsibility of the purchaser.

9.2.2 Mechanical Properties, Hardness, and Grain SizeSamples of the material to provide test specimens for mechanical properties, hardness, and grain size shall be taken from such locations in each lot as to be representative of that lot. 


\section{DEVELOPMENT OF A CONTROLLED MATERIAL SPECIFICATION FOR ALLOY 617 FOR NUCLEAR APPLICATIONS}

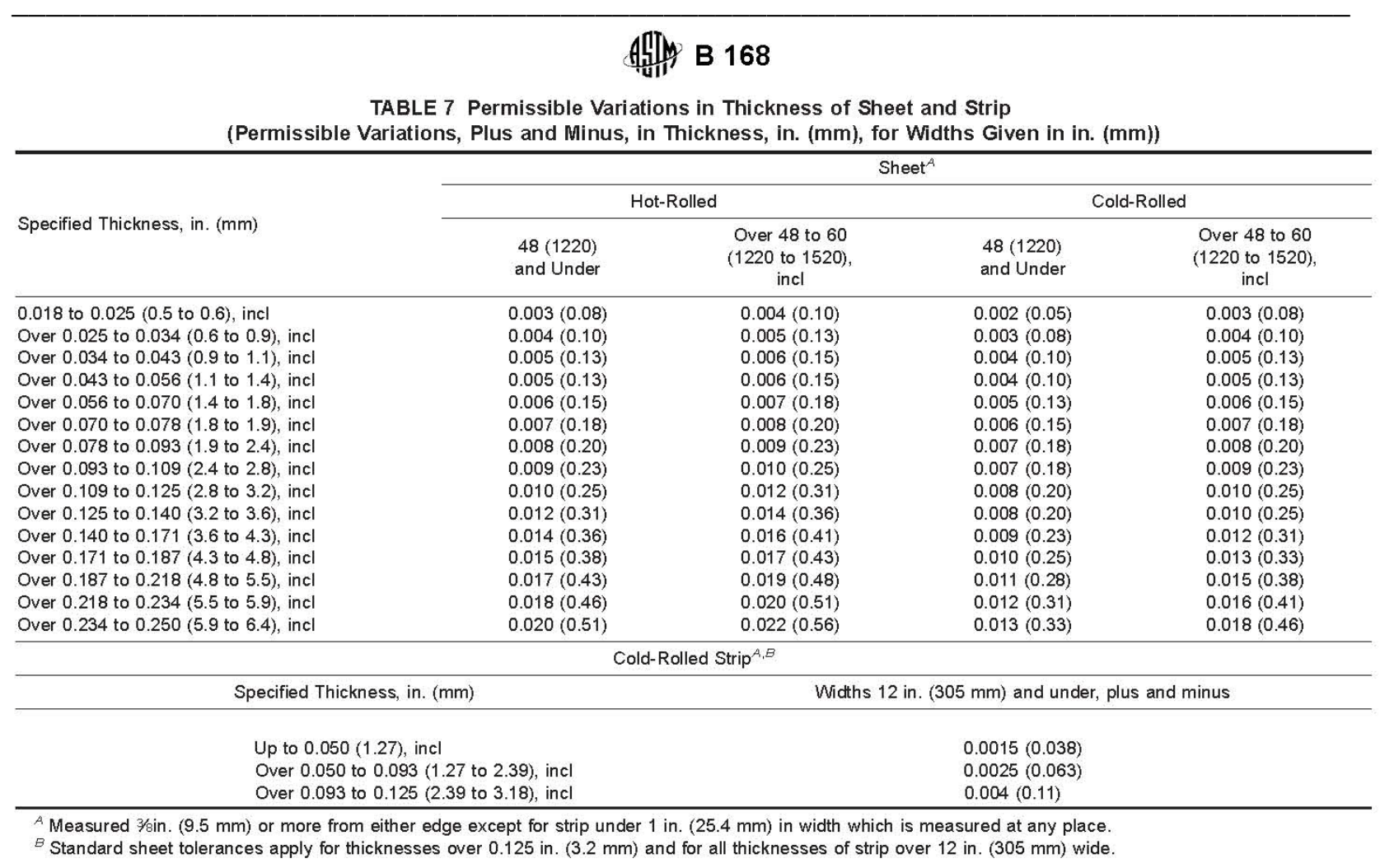

\section{Number of Tests}

10.1 Chemical Analysis-One test per lot.

10.2 Mechanical Properties - One test per lot.

10.3 Hardness - One test per lot. (Required only as specified in Table 3 and Table 4.)

10.4 Grain Size - One test per lot. (Required only as specified in Table 4.)

\section{Specimen Preparation}

11.1 Tension test specimens shall be taken from material in the final condition (temper) and tested transverse to the direction of rolling when width will permit.

11.2 Tension test specimens shall be any of the standard or subsize specimens shown in Test Methods E 8.

11.3 In the event of disagreement, referee specimens shall be as follows:

11.3.1 Full thickness of the material, machined to the form and dimensions shown for the sheet-type specimen in Test Methods E 8 for material under $1 / 2 \mathrm{in}$. $(12.7 \mathrm{~mm})$ in thickness.

11.3.2 The largest possible round specimen shown in Test Methods E 8 for material $1 / 2$ in. $(12.7 \mathrm{~mm}$ ) and over.

\section{Test Methods}

12.1 The chemical composition, mechanical, and other properties of the material as enumerated in this specification shall be determined, in case of disagreement, in accordance with the following methods:

$$
\text { Test }
$$

$$
\text { ASTM Designation }
$$

Chemical Analysis

Tension

Brinell hardness

Rockwell hardness

Hardness conversion

Grain size

Rounding procedure

Spring-back

E $38,{ }^{A}$ E 1473
E 8
E 10
E 18
E 140
E 112
E 29
F 155

A Methods $\mathrm{E} 38$ are to be used only for elements not covered by Test Methods E 1473.

12.2 The measurement of average grain size may be carried out by the planimetric method, the comparison method, or the intercept method described in Test Methods E 112. In case of dispute, the referee method for determining average grain size shall be the planimetric method.

12.3 For purposes of determining compliance with the 


\section{DEVELOPMENT OF A CONTROLLED MATERIAL SPECIFICATION FOR ALLOY 617 FOR NUCLEAR APPLICATIONS}

\begin{tabular}{|c|c|c|c|c|c|c|c|c|c|c|}
\hline \multirow{4}{*}{ Specified Thickness } & \multicolumn{9}{|c|}{ 然 B 168} & \\
\hline & \multicolumn{10}{|c|}{ Permissible Variations in Widths for Widths Given, in. (mm) } \\
\hline & \multicolumn{2}{|c|}{$\begin{array}{l}\text { Up to } 30(760) \\
\text { incl }\end{array}$} & \multicolumn{2}{|c|}{$\begin{array}{c}\text { Over } 30 \text { to } 72 \\
\text { (760 to } 1830) \\
\text { incl }\end{array}$} & \multicolumn{2}{|c|}{$\begin{array}{l}\text { Over } 72 \text { to } 108 \\
\text { (1830 to } 2740) \\
\text { incl }\end{array}$} & \multicolumn{2}{|c|}{$\begin{array}{l}\text { Over } 108 \text { to } 144 \\
(2740 \text { to } 3660) \\
\text { incl }\end{array}$} & \multicolumn{2}{|c|}{$\begin{array}{c}\text { Over } 144 \text { to } 160 \\
(3660 \text { to } 4070) \\
\text { incl }\end{array}$} \\
\hline & + & - & + & - & + & - & + & - & + & - \\
\hline \multicolumn{11}{|c|}{ Inches } \\
\hline \multicolumn{11}{|l|}{ Sheared: ${ }^{D}$} \\
\hline $3 / 16$ to $5 / 16$, excl & $3 / 16$ & $1 / 8$ & $1 / 4$ & $1 / 8$ & $3 / 8$ & $1 / 8$ & $1 / 2$ & $1 / 8$ & $\ldots$ & $\ldots$ \\
\hline $5 / 16$ to $1 / 2$, excl & $1 / 4$ & $1 / 8$ & $3 / 8$ & $1 / 8$ & $3 / 8$ & $1 / 8$ & $1 / 2$ & $1 / 8$ & $5 \%$ & $1 / 8$ \\
\hline $1 / 2$ to $3 / 4$, excl & $3 / 8$ & $1 / 8$ & $3 / 8$ & $1 / 8$ & $1 / 2$ & $1 / 8$ & $5 / 8$ & $1 / 8$ & $3 / 4$ & $1 / 8$ \\
\hline $3 / 4$ to 1 , excl & $1 / 2$ & $1 / 8$ & $1 / 2$ & $1 / 8$ & $5 \%$ & $1 / 8$ & $3 / 4$ & $1 / 8$ & $7 / 8$ & $1 / 8$ \\
\hline 1 to $1 \frac{1}{4}$, incl & $5 \%$ & $1 / 8$ & $5 \%$ & $1 / 8$ & $3 / 4$ & $1 / 8$ & $7 / 8$ & $1 / 8$ & 1 & $1 / 8$ \\
\hline Abrasive cut: $E, F$ & & & & & & & & & & \\
\hline $3 / 16$ to $11 / 4, \mathrm{incl}$ & $1 / 8$ & $1 / 8$ & $1 / 8$ & $1 / 8$ & $1 / 8$ & $1 / 8$ & $1 / 8$ & $1 / 8$ & $1 / 8$ & $1 / 8$ \\
\hline Over $11 / 4$ to $23 / 4$, incl & $3 / 16$ & $1 / 8$ & $3 / 16$ & $1 / 8$ & $3 / 16$ & $1 / 8$ & $3 / 16$ & $1 / 8$ & $3 / 16$ & $1 / 8$ \\
\hline Plasma-torch-cut: ${ }^{G}$ & & & & & & & & & & \\
\hline $3 / 16$ to 2, excl & $1 / 2$ & 0 & $1 / 2$ & 0 & $1 / 2$ & 0 & $1 / 2$ & 0 & $1 / 2$ & 0 \\
\hline 2 to 3 , incl & $5 \%$ & 0 & $5 \%$ & 0 & $5 \%$ & 0 & $5 / 8$ & 0 & $5 / 8$ & 0 \\
\hline \multicolumn{11}{|c|}{ Millimetres } \\
\hline \multicolumn{11}{|l|}{ Sheared: ${ }^{D}$} \\
\hline 4.8 to 7.9, excl & 4.8 & 3.2 & 6.4 & 3.2 & 9.5 & 3.2 & 12.7 & 3.2 & $\ldots$ & . \\
\hline 7.9 to $12.7, \mathrm{excl}$ & 6.4 & 3.2 & 9.5 & 3.2 & 9.5 & 3.2 & 12.7 & 3.2 & 15.9 & 3.2 \\
\hline 12.7 to 19.1 , excl & 9.5 & 3.2 & 9.5 & 3.2 & 12.7 & 3.2 & 15.9 & 3.2 & 19.1 & 3.2 \\
\hline 19.1 to $25.4, \mathrm{excl}$ & 12.7 & 3.2 & 12.7 & 3.2 & 15.8 & 3.2 & 19.1 & 3.2 & 22.2 & 3.2 \\
\hline 25.4 to 31.8 , incl & 15.9 & 3.2 & 15.9 & 3.2 & 19.1 & 3.2 & 22.2 & 3.2 & 25.4 & 3.2 \\
\hline \multicolumn{11}{|l|}{ Abrasive cut: $E, F$} \\
\hline 4.8 to 31.8 , incl & 3.2 & 3.2 & 3.2 & 3.2 & 3.2 & 3.2 & 3.2 & 3.2 & 3.2 & 3.2 \\
\hline Over 31.8 to & 4.8 & 3.2 & 4.8 & 3.2 & 4.8 & 3.2 & 4.8 & 3.2 & 4.8 & 3.2 \\
\hline \multirow{2}{*}{\multicolumn{11}{|c|}{ Plasma-torch-cut: $G$}} \\
\hline & & & & & & & & & & \\
\hline 4.8 to 50.8 , excl & 12.7 & 0 & 12.7 & 0 & 12.7 & 0 & 12.7 & 0 & 12.7 & 0 \\
\hline 50.8 to 76.2 , incl & 15.9 & 0 & 15.9 & 0 & 15.9 & 0 & 15.9 & 0 & 15.9 & 0 \\
\hline
\end{tabular}

${ }^{A}$ Permissible variations in width for powder- or inert-arc-cut plate shall be as agreed upon between the manufacturer and the purchaser

${ }^{B}$ Permissible variations in machined, powder-, or inert-arc-cut circular plate shall be as agreed upon between the manufacturer and the purchaser.

${ }^{C}$ Permissible variations in plasma-torch-cut sketch plates shall be as agreed upon between the manufacturer and the purchaser.

0 The minimum sheared width is $10 \mathrm{in}$. (254 mm) for material $3 / 4 \mathrm{in}$. (19.1 mm) and under in thickness and $20 \mathrm{in}$. (508 mm) for material over $3 / 4$ in. (19.1 mm) in thickness.

E The minimum abrasive-cut width is $2 \mathrm{in.}(50.8 \mathrm{~mm}$ ) and increases to 4 in. (101.6 mm) for thicker plates.

$F$ These tolerances are applicable to lengths of $240 \mathrm{in.}(6100 \mathrm{~mm})$, max. For lengths over $240 \mathrm{in}$., an additional $1 / 16$ in. (1.6 mm) is permitted, both plus and minus.

${ }^{G}$ The tolerance spread shown for plasma-torch cutting may be obtained all on the minus side, or divided between the plus and minus side if so specified by the purchaser.

specified limits for requirements of the properties listed in the following table, an observed value or a calculated value shall be rounded as indicated in accordance with the rounding method of Practice E 29.

Test

Chemical composition,
hardness, and toler-
ances (when ex-
pressed in decimals)

Tensile strength and

yield strength

Elongation

Grain Size:

0.0024 in. $(0.060 \mathrm{~mm})$

or larger

less than 0.0024 in

$(0.060 \mathrm{~mm})$

\author{
Rounded Unit for Observed \\ Or Calculated Value

nearest unit in the last right-
hand place of figures of the
specified limit. If two choices
are possible, as when the digits
dropped are exactly a 5 , or a
5 followed only by zeros,
choose the one ending in an
even digit, with zero defined
as an even digit.
nearest 1000 psi $(6.9 \mathrm{MPa})$
nearest $1 \%$
nearest multiple of 0.0002 in.
$(0.005 \mathrm{~mm})$
nearest multiple of 0.0001
in. $(0.002 \mathrm{~mm})$

\section{Inspection}

13.1 Inspection of the material shall be made as agreed upon between the manufacturer and the purchaser as part of the purchase contract.

\section{Rejection and Rehearing}

14.1 Material that fails to conform to the requirements of this specification may be rejected. Rejection should be reported to the producer or supplier promptly and in writing. In case of dissatisfaction with the results of the test, the producer or supplier may make claim for a rehearing.

\section{Certification}

15.1 When specified in the purchase order or contract, a manufacturer's certification shall be furnished to the purchaser stating that material has been manufactured, tested, and inspected in accordance with this specification, and that the test results on representative samples meet specification requirements. When specified in the purchase order or contract, a report of the test results shall be furnished.

\section{Product Marking}

16.1 Each bundle or shipping container shall be marked with the name of the material or UNS number; condition (temper); this specification number; the size; gross, tare, and net weight; consignor and consignee address; contract or order number; or such other information as may be defined in the contract or order. 


\section{DEVELOPMENT OF A CONTROLLED MATERIAL SPECIFICATION FOR ALLOY 617 FOR NUCLEAR APPLICATIONS}

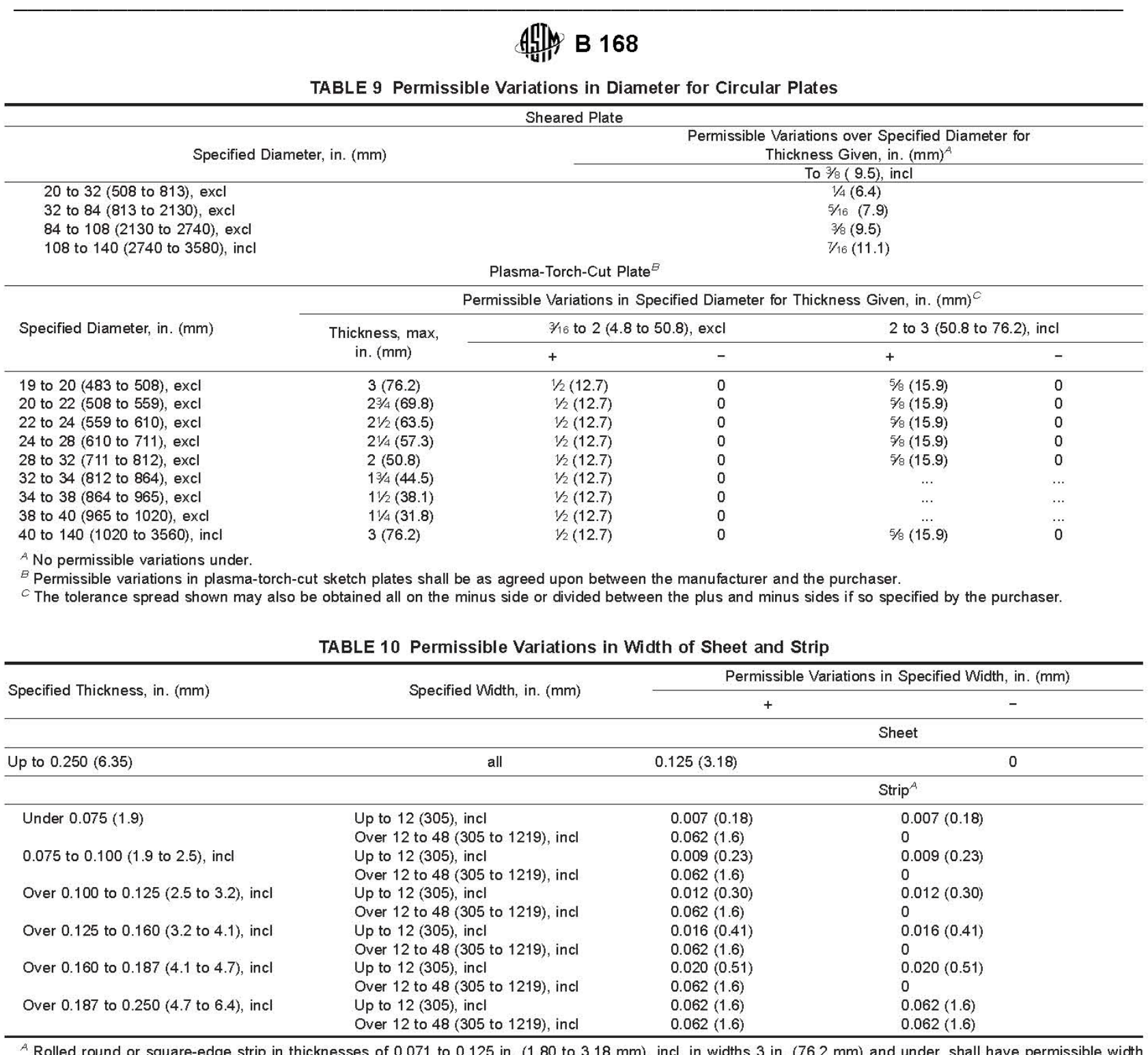

${ }^{A}$ Rolled round or square-edge strip in thicknesses of 0.071 to $0.125 \mathrm{in.}(1.80 \mathrm{to} 3.18 \mathrm{~mm})$, incl, in widths $3 \mathrm{in.}(76.2 \mathrm{~mm})$ and under, shall have permissible width variations of $\pm 0.005 \mathrm{in}$. ( $\pm 0.13 \mathrm{~mm})$. Permissible variations for other sizes shall be as agreed upon between the manufacturer and the purchaser.

\section{Keywords}

17.1 plate; sheet; strip; UNS N06025; UNS N06045; UNS N06600; UNS N06601; UNS N06603; UNS N06617; UNS N06690; UNS N06693 


\section{DEVELOPMENT OF A CONTROLLED MATERIAL SPECIFICATION FOR ALLOY 617 FOR NUCLEAR APPLICATIONS}

\begin{tabular}{|c|c|c|c|c|c|c|c|c|c|c|c|c|c|c|c|c|}
\hline \multirow{3}{*}{ Specified Thickness } & \multicolumn{16}{|c|}{ Permissible Variation in Length for Lengths Given, in. (mm) } \\
\hline & \multicolumn{2}{|c|}{$\begin{array}{l}\text { Up to } 60 \\
(1520) \text {, incl }\end{array}$} & \multicolumn{2}{|c|}{$\begin{array}{l}\text { Over } 60 \text { to } 96 \\
\text { ( } 1520 \text { to } 2440 \text { ), } \\
\text { incl }\end{array}$} & \multicolumn{2}{|c|}{$\begin{array}{l}\text { Over } 96 \text { to } 120 \\
(2440 \text { to } 3050) \text {, } \\
\text { incl }\end{array}$} & \multicolumn{2}{|c|}{$\begin{array}{l}\text { Over } 120 \text { to } 240 \\
\text { ( } 3050 \text { to } 6096) \text {, } \\
\text { incl }\end{array}$} & \multicolumn{2}{|c|}{$\begin{array}{l}\text { Over } 240 \text { to } 360 \\
\text { (6096 to } 9144), \\
\text { incl }\end{array}$} & \multicolumn{2}{|c|}{$\begin{array}{l}\text { Over } 360 \text { to } 450 \\
(9144 \text { to } \\
11430) \text {, incl }\end{array}$} & \multicolumn{2}{|c|}{$\begin{array}{l}\text { Over } 450 \text { to } 540 \\
(11430 \text { to } \\
13716) \text {, incl }\end{array}$} & \multicolumn{2}{|l|}{$\begin{array}{l}\text { Over } 540 \\
(13716)\end{array}$} \\
\hline & + & - & + & - & + & - & + & - & + & - & + & - & + & - & + & - \\
\hline \multicolumn{17}{|c|}{ Inches } \\
\hline \multicolumn{17}{|l|}{ Sheared: ${ }^{D}$} \\
\hline $3 / 16$ to $5 / 16$, excl & $3 / 16$ & $1 / 8$ & $1 / 4$ & $1 / 8$ & 3/8 & $1 / 8$ & $1 / 2$ & $1 / 8$ & $5 / 8$ & $1 / 8$ & $3 / 4$ & $1 / 8$ & $7 / 8$ & $1 / 8$ & $\ldots$ & $\ldots$ \\
\hline $5 / 16$ to $1 / 2$, excl & $3 / 8$ & $1 / 8$ & $1 / 2$ & $1 / 8$ & $1 / 2$ & $1 / 8$ & $1 / 2$ & $1 / 8$ & $5 / 8$ & $1 / 8$ & $3 / 4$ & $1 / 8$ & $7 / 8$ & $1 / 8$ & 1 & $1 / 8$ \\
\hline $1 / 2$ to $3 / 4$, excl & $1 / 2$ & $1 / 8$ & $1 / 2$ & $1 / 8$ & $5 / 8$ & $1 / 8$ & $5 / 8$ & $1 / 8$ & $3 / 4$ & $1 / 8$ & $7 / 8$ & $1 / 8$ & $11 / 8$ & $1 / 8$ & $13 / 8$ & $1 / 8$ \\
\hline $3 / 4$ to 1 , excl & $5 / 8$ & $1 / 8$ & $5 / 8$ & $1 / 8$ & $5 / 8$ & $1 / 8$ & $3 / 4$ & $1 / 8$ & $7 / 8$ & $1 / 8$ & $11 / 8$ & $1 / 8$ & $13 / 8$ & $1 / 8$ & $15 \%$ & $1 / 8$ \\
\hline $\begin{array}{l}1 \text { to } 1 \frac{114 \text {, incl }}{} \\
\text { Abrasive-cut: } E\end{array}$ & $3 / 4$ & $1 / 8$ & $3 / 4$ & $1 / 8$ & $3 / 4$ & $1 / 8$ & $7 / 8$ & $1 / 8$ & $11 / 8$ & $1 / 8$ & $13 / 8$ & $1 / 8$ & $15 \%$ & $1 / 8$ & $\ldots$ & $\ldots$ \\
\hline $3 / 16$ to $11 / 4$, incl & $1 / 8$ & $1 / 8$ & $1 / 8$ & $1 / 8$ & $1 / 8$ & $1 / 8$ & $1 / 8$ & $1 / 8$ & $1 / 8$ & $1 / 8$ & $1 / 8$ & $1 / 8$ & $\ldots$ & $\ldots$ & $\ldots$ & $\ldots$ \\
\hline $\begin{array}{l}\text { Over } 11 / 4 \text { to } 2 \\
3 / 4 \text {, incl }\end{array}$ & $3 / 16$ & $1 / 8$ & $3 / 16$ & $1 / 8$ & $3 / 16$ & $1 / 8$ & $3 / 16$ & $1 / 8$ & $3 / 16$ & $1 / 8$ & $3 / 16$ & $1 / 8$ & $\ldots$ & $\ldots$ & $\ldots$ & $\ldots$ \\
\hline \multicolumn{17}{|l|}{ Plasma torch-cut: ${ }^{F}$} \\
\hline $3 / 16$ to 2 , excl & $1 / 2$ & 0 & $1 / 2$ & 0 & $1 / 2$ & 0 & $1 / 2$ & 0 & $1 / 2$ & 0 & $1 / 2$ & 0 & $1 / 2$ & 0 & $1 / 2$ & 0 \\
\hline 2 to 3 , incl & $5 / 8$ & 0 & $5 / 8$ & 0 & $5 / 8$ & 0 & $5 / 8$ & 0 & $5 / 8$ & 0 & $5 / 8$ & 0 & $5 / 8$ & 0 & $5 / 8$ & 0 \\
\hline \multicolumn{17}{|c|}{ Millimetres } \\
\hline \multicolumn{17}{|l|}{ Sheared: ${ }^{D}$} \\
\hline 4.8 to 7.9 , excl & 4.8 & 3.2 & 6.4 & 3.2 & 9.5 & 3.2 & 12.7 & 3.2 & 15.9 & 3.2 & 19.0 & 3.2 & 22.2 & 3.2 & 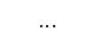 & \\
\hline 7.94 to $12.7, \mathrm{excl}$ & 9.5 & 3.2 & 12.7 & 3.2 & 12.7 & 3.2 & 12.7 & 3.2 & 15.9 & 3.2 & 19.0 & 3.2 & 22.2 & 3.2 & 25.4 & 3.2 \\
\hline 12.7 to $19.0, \mathrm{excl}$ & 12.7 & 3.2 & 12.7 & 3.2 & 15.9 & 3.2 & 15.9 & 3.2 & 19.0 & 3.2 & 22.2 & 3.2 & 28.6 & 3.2 & 34.9 & 3.2 \\
\hline 19.0 to $25.4, \mathrm{excl}$ & 15.9 & 3.2 & 15.9 & 3.2 & 15.9 & 3.2 & 19.0 & 3.2 & 22.2 & 3.2 & 28.6 & 3.2 & 34.9 & 3.2 & 41.3 & 3.2 \\
\hline \multirow{2}{*}{\multicolumn{17}{|c|}{ Abrasive-cut: ${ }^{E}$}} \\
\hline & & & & & & & & & & & & & & & & \\
\hline 4.8 to 31.8 , incl & 3.2 & 3.2 & 3.2 & 3.2 & 3.2 & 3.2 & 3.2 & 3.2 & 3.2 & 3.2 & 3.2 & 3.2 & $\ldots$ & $\ldots$ & $\ldots$ & $\ldots$ \\
\hline $\begin{array}{l}\text { Over } 31.8 \text { to } 69.9, \\
\text { incl }\end{array}$ & 4.8 & 3.2 & 4.8 & 3.2 & 4.8 & 3.2 & 4.8 & 3.2 & 4.8 & 3.2 & 4.8 & 3.2 & $\ldots$ & $\ldots$ & $\ldots$ & ... \\
\hline \multicolumn{17}{|l|}{ Plasma torch-cut: ${ }^{F}$} \\
\hline 4.8 to $50.8, \mathrm{excl}$ & 12.7 & 0 & 12.7 & 0 & 12.7 & 0 & 12.7 & 0 & 12.7 & 0 & 12.7 & 0 & 12.7 & 0 & 12.7 & 0 \\
\hline 50.8 to 76.2 , incl & 15.9 & 0 & 15.9 & 0 & 15.9 & 0 & 15.9 & 0 & 15.9 & 0 & 15.9 & 0 & 15.9 & 0 & 15.9 & 0 \\
\hline
\end{tabular}

${ }^{A}$ Permissible variations in length for powder- or inert-arc-cut plate shall be agreed upon between the manufacturer and the purchaser.

${ }^{B}$ The tolerance spread shown for plasma-torch-cutting may be obtained all on the minus side, or divided between the plus and minus sides if so specified by the purchaser.

C Permissible variations in machined, powder- or inert-arc-cut circular plate shall be as agreed upon between the manufacturer and the purchaser.

$D$ The minimum sheared length is 10 in. $(254 \mathrm{~mm})$.

E Abrasive cut applicable to a maximum length of 144 to 400 in. (3658 to $10160 \mathrm{~mm}$ ) depending on the thickness and width ordered.

$F$ The tolerance spread shown for plasma-torch-cut sketch plates shall be as agreed upon between the manufacturer and the purchaser. 


\section{DEVELOPMENT OF A CONTROLLED MATERIAL SPECIFICATION FOR ALLOY 617 FOR NUCLEAR APPLICATIONS}

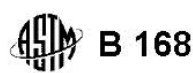

TABLE 12 Permissible Variations from Flatness of Rectangular, Circular, and Sketch Plates

Noте 1 -Permissible variations apply to plates up to $12 \mathrm{ft}(3660 \mathrm{~mm})$ in length, or to any $12 \mathrm{ft}(3660 \mathrm{~mm})$ of longer plates.

Note 2-If the longer dimension is under $36 \mathrm{in}$. (914 mm), the permissible variation is not greater than $1 / 4 \mathrm{in}$. $(6.4 \mathrm{~mm})$.

NoтE 3-The shorter dimension specified is considered the width, and the permissible variation in flatness across the width does not exceed the tabular amount of that dimension.

Nоте 4-The maximum deviation from a flat surface does not customarily exceed the tabular tolerance for the longer dimension specified.

\begin{tabular}{|c|c|c|c|c|c|c|c|c|c|}
\hline \multirow[b]{2}{*}{ Specified Thickness } & \multicolumn{9}{|c|}{ Permissible Variations from a Flat Surface for Thickness and Widths Given, in. (mm) } \\
\hline & $\begin{array}{c}\text { To } 48 \\
(1220) \\
\text { excl }\end{array}$ & $\begin{array}{c}48 \text { to } 60 \\
(1220 \text { to } \\
1520) \\
\text { excl }\end{array}$ & $\begin{array}{c}60 \text { to } 72 \\
(1520 \text { to } \\
1830) \\
\text { excl }\end{array}$ & $\begin{array}{c}72 \text { to } 84 \\
(1830 \text { to } \\
2130), \\
\text { excl }\end{array}$ & $\begin{array}{l}84 \text { to } 96 \\
(2130 \text { to } \\
2440) \\
\text { excl }\end{array}$ & $\begin{array}{l}96 \text { to } 108 \\
(2440 \text { to } \\
2740) \\
\text { excl }\end{array}$ & $\begin{array}{c}108 \text { to } 120 \\
(2740 \text { to } \\
3050) \\
\text { excl }\end{array}$ & $\begin{array}{c}120 \text { to } 144 \\
(3050 \text { to } \\
3660) \\
\text { excl }\end{array}$ & $\begin{array}{l}144 \\
(3660), \\
\text { and over }\end{array}$ \\
\hline \multicolumn{10}{|c|}{ Inches } \\
\hline $3 / 16$ to $1 / 4$, excl & $3 / 4$ & $11 / 16$ & $11 / 4$ & $13 \%$ & $15 \%$ & $15 \%$ & $\ldots$ & $\ldots$ & $\ldots$ \\
\hline $1 / 4$ to $3 / 8$, excl & $11 / 16$ & $3 / 4$ & $15 / 16$ & $11 \% 8$ & $13 / 8$ & $17 / 16$ & $1 \% 16$ & $17 \%$ & $\ldots$ \\
\hline $3 / 8$ to $1 / 2$, excl & $1 / 2$ & $9 / 16$ & $11 / 16$ & $3 / 4$ & $15 / 16$ & $11 / 8$ & $11 / 4$ & $17 / 16$ & $13 / 4$ \\
\hline $1 / 2$ to $3 / 4$, excl & $1 / 2$ & $9 / 16$ & $5 / 8$ & $5 / 8$ & $13 / 16$ & $11 / 8$ & $11 / 8$ & $11 / 8$ & $13 / 8$ \\
\hline $3 / 4$ to 1 , excl & $1 / 2$ & $9 / 16$ & $5 / 8$ & $5 / 8$ & $3 / 4$ & $13 / 16$ & $15 / 16$ & 1 & $11 / 8$ \\
\hline 1 to 2 , excl & $1 / 2$ & $9 / 16$ & $9 / 16$ & $9 / 16$ & $11 / 16$ & $11 / 16$ & $11 / 16$ & $3 / 4$ & 1 \\
\hline 2 to 4 , incl & $1 / 4$ & $5 / 16$ & $\not / 8$ & $7 / 16$ & $1 / 2$ & $9 / 16$ & $5 / 8$ & $3 / 4$ & $7 / 8$ \\
\hline \multicolumn{10}{|c|}{ Millimetres } \\
\hline 4.8 to 6.4 , excl & 19.0 & 27.0 & 31.8 & 34.9 & 41.3 & 41.3 & $\ldots$ & $\ldots$ & $\ldots$ \\
\hline 6.4 to 9.5 , excl & 17.5 & 19.0 & 23.8 & 28.6 & 34.9 & 36.5 & 39.7 & 47.6 & $\ldots$ \\
\hline 9.5 to 12.7 , excl & 12.7 & 14.3 & 17.5 & 19.0 & 23.8 & 28.6 & 31.8 & 36.5 & 44.4 \\
\hline 12.7 to 19.0 , excl & 12.7 & 14.3 & 15.9 & 15.9 & 20.6 & 28.6 & 28.6 & 28.6 & 34.9 \\
\hline 19.0 to 25.4 , excl & 12.7 & 14.3 & 15.9 & 15.9 & 19.0 & 20.6 & 23.8 & 25.4 & 28.6 \\
\hline 25.4 to 50.8 , excl & 12.7 & 14.3 & 14.3 & 14.3 & 17.5 & 17.5 & 17.5 & 19.0 & 25.4 \\
\hline 50.8 to 101.6 , incl & 6.4 & 7.9 & 9.5 & 11.1 & 12.7 & 14.3 & 15.9 & 19.0 & 22.2 \\
\hline
\end{tabular}

\section{SUPPLEMENTARY REQUIREMENTS}

The following supplementary requirements shall apply only when specified by the purchaser in the inquiry, contract, or order, for agencies of the U. S. Government.

\section{S1. Referenced Documents}

S1.1 The following documents of the issue in effect on date of material purchased form a part of this specification to the extent referenced herein: Federal Standards 102, 123, and 182 and Military Standard MLL-STD-129.

\section{S2. Quality Assurance}

S2.1. Responsibility for Inspection-Unless otherwise specified in the contract or purchase order, the manufacturer is responsible for the performance of all inspection and test requirements specified. Except as otherwise specified in the contract or purchase order, the manufacturer may use his own or any other suitable facilities for the performance of the inspection and test requirements unless disapproved by the purchaser at the time the order is placed. The purchaser shall have the right to perform any of the inspections or tests set forth when such inspections and tests are deemed necessary to ensure that the material conforms to prescribed requirements.

\section{S3. Identification Marking}

S3.1 All material shall be properly marked for identification in accordance with Fed. Std. No. 182, except that the ASTM specification number and the alloy number shall be used.

\section{S4. Preparation for Delivery}

\section{S4.1 Preservation, Packaging, Packing:}

S4.1.1 Military Agencies - The material shall be separated by size, composition, grade, or class and shall be preserved and packaged, Level A or C or packed, Level A, B, or C as specified in the contract or purchase order.

S4.1.2 Civil Agencies-The requirements of Fed. Std. No. 102 shall be referenced for definitions of the various levels of packaging protection.

\section{S4.2 Marking:}

S4.2.1 Military Agencies - In addition to any special marking required by the contract or purchase order, marking for shipment shall be in accordance with MIL-STD-129.

S4.2.2 Civil Agencies - In addition to any special marking required by the contract or purchase order, marking for shipment shall be in accordance with Fed. Std. No. 123. 


\section{DEVELOPMENT OF A CONTROLLED MATERIAL SPECIFICATION FOR ALLOY 617 FOR NUCLEAR APPLICATIONS}

然 B 168

APPENDIX

(Nonmandatory Information)

X1. CONDITIONS AND FINISHES

\section{X1.1 Scope}

X1.1.1 This appendix lists the conditions and finishes in which plate, sheet, and strip are normally supplied. These are subject to change, and the manufacturer should be consulted for the latest information available.

\section{X1.2 Plate, Hot-Rolled}

X1.2.1 Annealed - Soft with an oxide surface, and suitable for heavy cold forming. Available with a descaled surface, when so specified.

X1.2.2 As-Rolled - With an oxide surface. Available with a descaled surface, when so specified. Suitable for flat work, mild forming, or tube sheets. When intended for tube sheets, specify that plates are to be specially flattened. When intended for hot forming, this should be indicated on the purchase order so that the manufacturer may select appropriate material.

\section{X1.3 Plate, Cold-Rolled}

X1.3.1 Annealed - Soft with an oxide surface; available in a descaled surface when so specified.

\section{X1.4 Sheet, Hot-Rolled}

X1.4.1 Annealed and Pickled-Soft with a pickled matte finish. Properties similar to X1.5.1 but with broader thickness tolerances. Not suggested for applications where the finish of a cold-rolled sheet is considered essential, or for deep drawing or spinning.

\section{X1.5 Sheet and Strip, Cold-Rolled}

X1.5.1 Annealed -Soft with a pickled or bright annealed finish.

X1.5.2 Deep-Drawing or Spinning Quality__Similar to $\mathrm{X} 1.5 .1$, except furnished to controlled hardness and grain size and lightly leveled.

X1.5.3 Skin-Hard - Similar to X1.5.1, but given a light cold reduction to hardness range shown in Table 3 .

X1.5.4 Quarter-Hard - Cold rolled to the hardness range indicated in Table 3, bright finish. Out-of-flatness must be expected and will vary with temper and thickness.

X1.5.5 Half-Hard - Cold rolled to the hardness range indicated in Table 3, bright finish. Out-of-flatness must be expected and will vary with temper and thickness.

X1.5.6 Three-Quarter Hard - Cold rolled to the hardness range indicated in Table 3 , bright finish. Out-of-flatness must be expected and will vary with temper and thickness.

X1.5.7 Hard - Cold rolled to the tensile requirements indicated in Table 3, bright finish. Out-of-flatness must be expected and will vary with temper and thickness.

X1.5.8 Spring Temper - Cold rolled to the minimum hardness indicated in Table 3 , bright finish. Out-of-flatness must be expected and will vary with temper and thickness.

ASTM international takes no position respecting the validity of any patent rights asserted in connection with any item mentioned
in this standard. Users of this standard are expressly advised that determination of the validity of any such patent rights, and the risk of infingement of such rights, are entirely their own responsibility.

This standard is subject to revision at any time by the responsible technical committee and must be reviewed every five years and if not revised, either reapproved or withdrawn. Your comments are invited either for revision of this standard or for additional standards and should be addressed to ASTM international Headquarters. Your comments will receive careful consideration at a meeting of the responsible technical committee, which you may attend. If you feel that your comments have not received a fair hearing you should make your views known to the ASTM Committee on Standards, at the address shown below.

This standard is copyrighted by ASTM international, 100 Barr Harbor Drive, PO Box C700, West Conshohocken, PA 19428-2959, United States. Individual reprints (single or multiple copies) of this standard may be obtained by contacting ASTM at the above address or at 610-832-9585 (phone), 610-832-9555 (fax), or service@astm.org (e-mail); or through the ASTM website (www. astm.org). 